\title{
JOHN MARSHALL HARLAN AND THE CONSTITUTIONAL RIGHTS OF NEGROES: THE TRANSFORMATION OF A SOUTHERNER*
}

\author{
ALAN F. WESTIN†
}

WheN the United States Supreme Court announced its decision in the Segregation Cases, ${ }^{1}$ a New York Times editorial commenting on the decision was headed, appropriately enough, "Justice Harlan Concurring." The editorial began:

"It is eighty-six years since the Fourteenth Amendment was proclaimed a part of the United States Constitution. It is fifty-eight years since the Supreme Court, with Justice Harlan dissenting, established the doctrine of 'separate but equal' provision for the white and Negro races on interstate carriers. It is forty-three years since John Marshall Harlan passed from this earth. Now the words he used in his lonely dissent in an 8-to-1 decision in the case of Plessy v. Ferguson in 1896 have become in effect by last Monday's unanimous decision of the Supreme Court a part of the law of the land.

"Justice Harlan said: 'Our Constitution is color-blind and neither knows nor tolerates classes among citizens. . . The arbitrary separation of citizens on the basis of race ... is a badge of servitude wholly inconsistent with the civil freedom and the equality before the law established by the Constitution.'

"Last Monday's case dealt solely with segregation in the schools, but there was not one word in Chief Justice Warren's opinion that was inconsistent with the earlier views of Justice Harlan. This is an instance in which the voice crying in the wilderness finally becomes the expression of a people's will and in which justice overtakes and thrusts aside a timorous expediency."2

The image of John Marshall Harlan standing in solitary disagreement with his colleagues on the segregation issue and being vindicated by the unfolding of American history has long been an intriguing picture to students of constitutional law. ${ }^{3}$ Even more intriguing has been the fact that Harlan was one

*Copyright 1957 by Alan $\mathrm{F}$. Westin.

†Senior Fellow, Yale Law School, 1956-57; Assistant Professor of Government, Cornell University.

1. Brown v. Board of Education, 347 U.S. 483 (1954); Bolling v. Sharpe, 347 U.S. 497 (1954).

2. N.Y. Times, May 23, 1954, \& 4, p. 10E, cols. 1, 2.

3. See Brown, The Dissenting Opinions of Mr. Justice Harlan, 46 AMr. L. Rev. 321, 335-38 (1912); Clark, The Constitutional Doctrines of Justice Harlan 89-92, 126- 
of the two Southerners on the Supreme Court in 1896, and that he had once been a slaveholder, an opponent of the Emancipation Proclamation, a bitter foe of the Civil War Amendments and a critic of federal civil rights legislation.

Because slavery and Negro civil rights were at the heart of Kentucky politics in Harlan's day and because the constitutional questions raised by emancipation came before the Supreme Court throughout his career on the bench, the story of Harlan's civil rights odyssey actually spans his entire lifetime. Within the scope of a single article, it is possible only to sketch the main outlines of this story. A more detailed account of Harlan's life as a Kentucky statesman and of his judicial philosophy as a Justice will be developed in additional articles and a forthcoming biography. ${ }_{4}^{4}$

\section{The Rise and Fall of a White Supremacist Forging the Earliest Faiths}

The Bluegrass State of John Marshall Harlan's birth in 1833 was borderland, surrounded on the north by Ohio, Indiana and Illinois, and on the south by Virginia and Tennessee, with Missouri and West Virginia at its sides. Once a stronghold of Jeffersonian Republicanism, Kentucky had swung into the Whig columns in 1824 under the creative leadership of Henry Clay, to remain there for more than twenty-five years. ${ }^{5}$ With his father a close friend of "Prince Hal" and a dominant figure in Kentucky's Whig councils, John Harlan was imbued with the Whig credo as his natural faith. Growing up in the manorial Ashland District, with the Clays, Crittendens and Breckinridges as neighbors and a household staffed with Negro slaves, Harlan exemplified the southern Whig tradition. As a boy, Harlan recalled later, he stood among the audience in picnic groves and torchlight parades listening to Henry Clay expound the gospel of a national bank, a national tariff and a

43 (1915) ; Knight, The Dissenting Opinions of Justice Harlan, 51 Axr. L. Rev. 481, 498501. (1917); Watt \& Orlikoff, The Coming Vindication of Mr. Justice Harlan, 44 ILL. L. Rev. 13 (1949) ; Waite, The Negro in the Supreme Court, 30 MrNs. L. Rev. 219, 239-67 (1946) ; Waite, How "Eccentric" Was Mr. Justice Harlan?, 37 MrN. L. Rev. 173, 18286 (1953) ; Beth, Justice Harlan and the Uses of Dissent, 49 AMr. Pol. Scr. Rev. 1085, 1086-92 (1955).

4. The author's work on Harlan was begun in 1951 from the portion of Justice Harlan's papers deposited in the University of Louisville Law School. Since that time, the main body of Harlan Papers has been loaned to the author by the present Justice John M. Harlan and Harlan letters in the Library of Congress have been examined. I would like to express my deep appreciation to Justice Harlan; to Dean A. C. Russell and Mrs. Pearl Von Allmen of the University of Louisville Law School; and to Dr. David C. Mearns of the Manuscript Division, Library of Congress. I owe a special debt to Dean Eugene Rostow and the Faculty of Yale Law School, for making possible a year of concentration on the Harlan Papers in the most pleasant and stimulating of surroundings.

5. For general histories of Kentucky, see Clark, A Hrstory of Kentucky (1937); History of Keatucky (Kerr ed. 1922) (Only the second volume of the five volume set has been referred to in this Article; as it was done entirely by Connelly and Coulter, this work will hereinafter be cited as 2 CONNelly \& Coulter); E. P. Johnson, A History of Kentucky and Kentuckians (1912). 
supreme law of the land, while his father defended the same Whig tenets in his successful campaigns for Secretary of State of Kentucky, State Attorney General and Congressman from his home district. ${ }^{6}$ As a student at Centre College, in Danville, Harlan joined the young Kentucky gentlemen sent to learn their Presbyterian fundamentals, beginning a life-long devotion to Sabbath observance, temperance and Bible study at this school where "the moral and religious culture of the youth has always been regarded by the officers of the College as their most important object." "7 At seventeen Harlan left Centre to study law at Transylvania University, "the Harvard of the West." Under the guidance of teachers like Judges George Robertson and Thomas Marshall of the Kentucky Court of Appeals, Harlan dipped into Coke, Blackstone and Littleton, read Kent and Story, and, above all, absorbed the nationalist philosophy of his namesake, Chief Justice John Marshall. It was on a note of allegiance to that faith that Harlan left Transylvania. With secession rumbling in the eaves in the early 1850's, Judge Robertson delivered an address in 1852 to the senior class at Transylvania, defending the supremacy of the Constitution against the "pernicious errors" of the secessionists and expounding the ideas of Washington, Hamilton, Marshall and Clay. 3 Heading a three man petition to publish the address was the signature of John Marshall Harlan, condemning "the monstrous doctrines of nullification and secession, which threaten, ere long, unless firmly resisted by the patriotic intelligence of the people, to undermine the fabric of our Government. . ..."9

6. Letter from John Marshall Harlan (J.M.H.) to Richard Harlan, July, 1911, 32 pp., Harlan Papcrs, Author's Possession (hereinafter cited as Autobiographical Letter).

7. Catalog of the Officers and Students of Centre College, Danville, 1850, at 14-15. Harlan taught a Sunday School class regularly, was First Moderator of the Presbyterian Church in the United States, and, during his summer vacations, was in charge of managing the affairs of the Murray Bay Church, an interdenominational Protestant chapel maintained at the Canadian resort. Typical of Harlan's deeply held views on religion are the following two items. In an interview given to a reporter in 1906, Harlan stated:

"[I] believe that the Bible is the inspired Word of God. Nothing which it commands can be safely or properly disregarded-nothing that it condemns can be justified. No civilization is worth preserving which is not based on the doctrines or teachings of the Bible."

Morrow, Talks With Notable Men: John M. Harlan, Washington Post, Feb. 23, 1906, Harlan Pafers, Lonisville. This fervor was not simply for public consumption. In a private letter written to Professor W. A. Maury of Columbia Law School, Harlan said:

"[T]he vast majority of the American people would have preferred that there be no World's Fair, under the patronage of America, if it was to be attended by a deliberate desecration of the Christian Sabbath .... The assumption that the laboring man demands the opening of the Fair on Sunday is a fraudulent pretense. The rich lounger, who does not earn his own salt, and the fellows who sit around the saloons, are usually very loud in [this] expression... . The fact is, the genuine laboring man does not, as a rule, sympathize with any movement that contemplate's the desecration of the Sabbath."

Letter from J.M.H. to W. A. Maury, June 18, 1893, Harlan Papers, Lonisville.

S. Robertson, Scrapbook on Law and Pot.rtes, Men and Times 246-56 (1855).

9. Id. at 245 . 
Harlan emerged from Transylvania Law School and was admitted to the bar in 1853, eager to move into the legal and political world of the Kentucliy Whigs. At that moment his party was about to begin fifteen years of wandering in a political wasteland, too nationalist to merge with the Democrats and too Southern to join the Free-Soilers or Republicans. With the deaths of Clay and Webster in 1852, the smoldering conflict over slavery flared up to divide the Whig Party into a Northern and a Southern camp; in Kentucky and elsewhere the local Whigs tried to side-step the slavery issue temporarily and appeal to both pro-and anti-slavery supporters by raising the banner of American nativism. This took the form of the semi-secret Know-Nothing movement. ${ }^{10}$ Harlan was carried along with the move, and one of his autobiographical memoranda related his personal outlook on joining the nativists:

"The Know-Nothing Society was a secret organization, having for its object to restrict and destroy the influence of foreigners and Catholic priests in our political affairs. Its motto was, 'Put none but Americans on Guard.' In 1854, just after reaching twenty-one years of age, I was asked by a friend to join the Know-Nothings, my friend observing that all the old Whigs in the city were members of it. Well, I agreed to join, and did join the society. I was initiated in the upper, or grand jury room in the court house in Frankfort. On the evening of my initiation an oath ... was administered to me which bound me to vote only for native Americans, and, in effect, only for Protestants. I was very uncomfortable when the oath was administered to me. My conscience, for a time, rebelled against it. For a moment I had the thought of retiring; for while I was intense, as I still am, in my Protestantism, I did not relish the idea of proscribing anyone on account of his religion. But looking around the room in which the initiation occurred, I observed that the old Whig leaders of the city, including my father, were present, and I had not the boldness to repudiate the organization. So I remained in it, upon the idea that, all things considered, it was best for any organization to control public

10. The position of the Whig-American leaders was summarized in a speech made by Congressman Lewis D. Campbell of Ohio to a mass Know-Nothing rally in Washington during the 1856 campaign. After explaining that he and his fellow Know-Nothing, Senator John J. Crittenden of Kentucky, had been loyal Whigs since 1832, under the banner of "Harry of the West," Campbell declared:

"But it is now conceded that the Whig party is dead.... [T] hat question [slavery] has destroyed the Whig party. ... I always have maintained, maintain now, and expect to contend hereafter, that all the powers of the Constitution ought to be exercised to prevent its [slavery's] extension, and that the North should freely accord to the slave States, in good faith, all that is guaranteed to them by that American bond of Union which makes us one people, and binds us all to a common destiny. ..." Having explained why the slavery issue had "no legitimate connection" with the great reform proposals of the American Party, Rep. Campbell went on to discuss the "real" issues: the alleged activities of Catholics in building up "the political power of the Pope of Rome in America," the flood of "felons and paupers" to the United States under weak immigration laws, and the danger of voting power in the hands of the foreign-minded. Americanism. Speech of Hon. Lewis D. Campbell, of Ohio, delivered at the American Mass Mecting, held in Washington City, February 29th, 1856, Pamphlet Collection, Yale University Library. For the Kentucky Know-Nothing Party, including references to the roles of the Harlan family, see McGani, Nativism In Kentucky To 1860 (1944). 
affairs rather than to have the Democratic party in power. That was the kind of political meat upon which my father fed me as I grew up. $\mathrm{He}$ hated Democracy and its leaders, Jefferson, Jackson and Van Buren .... So I became reconciled to remaining in the Know-Nothing Society, notwithstanding its direct attack on the Catholic Church."11

Once in the party, the strapping six-foot, two-inch redhead plunged with gusto into the political campaigns of the 1850's. As a stump-speaker for the American ticket in the 1855 state elections, canvasser for the Know-Nothing Party's presidential nominee in 1856 (Millard Fillmore) and successful candidate for judge of Franklin County in 1858, John Harlan flashed into prominence as one of the most able young orators in the Bluegrass. Traveling on horseback from town to town and living out of a pair of saddle bags, debating Democratic speakers twice his age, Harlan began attracting huge audiences for his appearances. He was billed as the "young giant of the American Party,"12 and his speeches were described, approvingly, as "orthodox. . Know-Nothing scripture"13 - anti-foreign, pro-slavery and anti-Catholic in just the right proportions. But Harlan's efforts were rendered on behalf of a waning party. A1though the Americans won the state election of 1855, they failed to carry the state for Fillmore in the 1856 presidential contest and lost decisively in the state elections of 1857 and 1858 . Kentucky voters might have been worried, in a general way, about the future of "Romanism" in America, but it was slavery that they were most wrought up about, and on that score, the Democrats promised the most vigorous pro-slavery course. ${ }^{14}$

11. The Know-Nothing Organization-My First Appearance as a Public Speaker and Participation in the Presidential Campaign of 1856. Election as County Judge in 1858, and Contest for Representative in Congress in 1859. Race for Governor in 1871 and in 1S75. Recommended for Vice-President in 1872. Arrest of Dr. Mitchell, 23 pp., Harlan Papers, Author's Passession at 1-2 (hereinafter cited as Political Memorandum).

In 1S54, Harlan was appointed Notary Public for the County of Franklin and, in the same year, elected as City Attorney for Frankfort. He was re-elected City Attorney in 1856 and again in 1857. Frankfort Commonwealth, Jan. 8, Jan. 15, 1855; Jan. 5, 1857; Johnson, Tee History of Franklin County, Kr. 137 (1912). The population of Franklin County in 1850 was 12,462 , of whom 3,365 were slaves. Id. at 131.

12. Louisville Daily Journal, July 28,1856 , in Hartz, John M. Harlan in Kentucky, 1855-1877, The Story of His Pre-Court Political Career, 14 Finson Club Hist. Q. 17, 19 (1940) (hereinafter cited as Hartz). Professor Hartz's article, drawn from a summa undergraduate thesis in government at Harvard, is based almost entirely on a study of contemporary newspaper accounts of Harian's career and is an outstanding piece of research and writing.

While the Harlan Papers throw a different light on many incidents in the Justice's career, Professor Hartz's general portrait remains a true one. Except where fuller quotations from the Harlan clipping collection were necessary, this study has cited the newspaper accounts to the Hartz article, as a published work, or to the original manuscript, Hartz, The Individualist Philasophy of John Marshall Harlan (unpublished thesis in Harvard University Library, 1940).

13. Frankfort Commonwealth, May 21, 1856, Hartz, supra note 12, at 20.

14. The story of Kentucky's shift from Whig supremacy to a Democratic majority letween 1853 and 1860 is recounted well in 2 CoNNelly \& Coulter 842-52; also, SHaN- 
It is important, at this point in tracing John Harlan's career, to note the Harlan family's attitude toward slavery. ${ }^{15}$ The Harlan household included about a dozen slaves who had been inherited by James Harlan and his wife from their parents. Like many slaves in the state, these were house servants rather than field hands, for Kentucky was small farm country, not plantation land. The Harlans treated their slaves with great kindness, so much so that John's young wife, Mallie, was surprised to see how much a part of the Harlan family the Negroes were. "The close sympathy existing between the slaves and their Master or Mistress," Mallie wrote in recalling her early married years in the senior Harlan's mansion, "was a source of great wonder to me as a descendant of the Puritans, and I was often obliged to admit to myself that my former views of the 'awful institution of Slavery' would have to be somewhat modified." Justice Harlan remembered walking with his father one Sunday to church when they saw a husky overseer mistreating a group of chained slaves being transported through the town. The elder Harlan was so outraged that he marched up to the whip-wielder, shook his finger angrily in the man's face, and declared, "You are a damned scoundrel. Good morning, Sir." This sense of decency made the Harlans, like Henry Clay, emancipators, favoring such proposals as the African Colonization plan to rid the nation eventually of slavery ; personally, James Harlan manumitted several of his slaves and helped them to make a successful start in life as free men. However, the Harlans were strongly anti-abolitionist, believing that freeing all the slaves in their then condition of education would be disastrous, while any forced emancipation would be a violation of the property rights of American citizens. As the 1850's brought increased anti-slavery pressure from Northern abolitionists and Kentucky anti-slavers like Cassius Clay, the Harlans became increasingly committed to the defense of property rights in slaves, the right of the states to deal with slavery as they saw fit, and the obligation of the national government to protect slave property in the new territories. This was Harlan's perspective in the late 1850 's, and it was to remain basically the same for over a decade. ${ }^{10}$

Harlan's spectacular success as a campaigner in the 1855, 1856 and 1858 elections resulted in the nomination of the twenty-six year old county judge

non \& McQuown, Presidential Politics in Kentucky, 1824-1948, A Compilation of Election Statistics and an Analysis of Political Bemavior 28-44 (1950).

15. The following account is drawn from "The Harlan Slaves," a chapter in Malvina Shanklin Harlan, Some Memories of a Long Life, 1854-1911, at 12-20 (1915), a 188 page typescript autobiography written by Mrs. Harlan and preserved in the Harlan Papers, Author's Possession (hereinafter cited as Mrs. Harlan, Memories).

16. For accounts of the slave system in Kentucky, see Bancroft, SLAve-Traping IN the Old South (1931) ; Birney, James G. Birney and His Times (1890); Coleman, Slavery Tines in Kentucky (1940); McDougle, Slavery in Kentucky, 1792-1865 (1918); Martin, The Anti-Slavery Movement in Kentucky Prior to 1850 (1918). On Henry Clay, see Poage, Henry Clay and the Whig Party (1936) ; Van Dusen, The Life of Henry Clay (1937); and Works of Henry Clay (Colton ed. 1897).

In 1851, having instituted two suits for freedom on behalf of free Negroes who had been kidnapped and sold a second time into slavery, James Harlan found himself the target of 
as the candidate of the Opposition Party, (the latest Whig-American title), for the Ashland congressional race of 1859. Although the nomination had come as a complete surprise and even against his wishes, ${ }^{17}$ Harlan made a tireless canvass of his district, speaking in two and three towns a day during the closing weeks of the contest. ${ }^{18}$ His speeches were slashing attacks on the Buchanan Administration-for its "extravagance, corruption, and inefficiency" in the management of national revenues; for its "bankrupt project for placing State corporations at the mercy of Federal courts"; and for the Democratic proposal to place $\$ 30,000,000$ in the President's hand, "in advance, for purposes of bribery and corruption" to effectuate the purchase of Cuba. Religious issues remained in the campaign, with Harlan espousing Opposition Party proposals for a federal expeditionary force to march on Utah and put down the "Mormon rebellion" for its violations of Christian morality and national authority. The slavery question was the central dispute between Harlan and his Democratic opponent, however, and on this subject Harlan set out to prove himself the more devoted defender of property rights in slaves. Organizing his slavery talks around the Dred Scott case, Harlan declared that this decision had "judicially settled" the question of slavery in the territories, by holding that there was no power in Congress or in the territorial legislatures to exclude slavery there. Furthermore, Harlan stated, the Dred Scott case signified that "Congress had the power, and it was its bounded duty, to pass such laws as might be necessary for the full protection of the rights of the slave-owner in the Territories, whenever the local Legislatures shall either attempt to destroy his right by unfriendly legislation or shall fail to pass such laws as are necessary for his protection." In another speech, Harlan charged that the Southern Democrats had sold out the rights of the

denunciation as an "abolitionist agent." To a friend who asked him about the rumors, Harlan wrote explaining the facts in the suits and adding,

"I have never since I commenced the practice of law sought employment either from black or white persons; but nothing which may emanate from Negro traders or others will ever prevent me from instituting a suit for freedom if I believe the laws authorize it. ... He who applies [the term "abolitionist"] to me lies in his throat. ... I have the same opinion of an abolitionist that I have of a disunionist-Each deserves the gallows."

James Harlan to D. Howard Smith, Aug. 5, 1851, Harlan Papers, Author's Possession.

Like his father, John Harlan defended both free Negroes and slave owners in the courts while maintaining a straight Southern constitutional and political line on the general slavery issue. John Harlan's defense of free Negroes in court actions is recorded in his Law Ledgcr 1854, Harlan Papers, Author's Possession. For two appellate cases Harlan argued involving property rights in slaves, see Townes v. Durbin, $60 \mathrm{Ky}$. (3 Metc.) 352 (1860), and Earle v. Couch, $60 \mathrm{Ky}$. (3 Metc.) 450 (1861).

17. Political Memorandum, supra note 11, at 5-6.

18. For the newspaper reports of Harlan's appearances, see Hartz, supra note 12, at 21-23, and Hartz, The Individualist Philosophy of John Marshall Harlan, op. cit. supra note 12 , at 16 . The following account of Harlan's 1859 speeches is taken from Hartz and from The Discussion on Thursday, report and editorial in The Western Citizen (Paris, Kentucky), June 10, 1859, Harlan Papers, Author's Possession. 
Southern people and had embraced the principle of "squatter sovereignty" in return for a political alliance with the Douglas Democrats of the North. To Harlan, "squatter sovereignty" conflicted with the slaveowner's property rights under the Federal Constitution, and he condemned the Douglas concept as "a mobocratic idea which levels destruction at all written contracts" in the belief "that majorities can make and set aside constitutions at pleasure." For Harlan, the individual's rights to property in slaves, just as his right to "freedom of conscience, freedom of speech, freedom of the press, and the other privileges which are the birthright of American freemen . . . are not the mere concessions of majorities."

Harlan lost the Ashland congressional election by fifty votes, in what was widely regarded throughout Kentucky as a case of ballot-stuffing by the Democrats. Although his friends raised a $\$ 10,000$ purse to pay for a recount, he decided that it would be wiser, in the long run, to enjoy the sympathy of the fair-minded voters and not to contest the election. ${ }^{\mathbf{1 9}}$

\section{On the Horns of the National Dilemma}

Between 1859 and 1861 the steady pressure of events pushed Harlan and the Kentucky Whigs, reluctantly, from the politics of evasion to the final hard choice between slavery-with-secession and support of the Union. ${ }^{20}$ In 1860 the Harlans, as most Kentucky Whigs, backed Bell for President on the Constitutional Union ticket, dedicated to the noble and ambivalent goals of "The Union, the Constitution, and the Enforcement of the Laws." Following Lincoln's inauguration and the secession movements, John Harlan was among those trying desperately to stave off a war. In a letter to Joseph Holt written in March 1861, Harlan suggested a plan by which federal troops would be withdrawn from the seceding states, thereby avoiding bloodshed and giving a pro-Union party in those states the opportunity to spring up; then, through a National Convention called to mediate the issue, the Southern states would be brought back into the Union. ${ }^{21}$

19. Political Memorandum, supra note 11, at 8-9. Justice Harlan noted in his memorandum:

"I have often considered what might have been the effect upon my life if I had been returned as elected to Congress in 1859. Most probably one session of Congress in Washington, at my then age, would have given me such a taste for political life as would not have been consistent with professional success. On the whole, the men who conceived and carried out the frauds ... did me a great service. After the election I went diligently to work in the practice of law, and managed to pay off the Id. at 10 .

[ $\$ 9000]$ debt contracted on account of my campaign."

20. The best monograph on Kentucky in this period is Coulter, ThE CIVIL WAR AND ReadjustMent in KentuCKy (1926). Also helpful to the author were Mruitury HisTORY OF Kentucky (Federal Writers Project, W.P.A., Kentucky 1939) and 2 Conneicy \& COULTER.

21. Letter from J.M.H. to Joseph Holt, March 11, 1861, Holt Papers, Manuscript Division, Library of Congress. 
"Good men tried to keep the peace [Harlan recalled] and forebore to say or do anything that would serve as an excuse to resist the authority of the Union. At last, the actual crisis came, when the Flag of the United States, floating over a Fort of the United States in the harbor of Charleston, was fired upon, without cause, and the authority of the Union defied. . . Then the people in the non-slaveholding states and the Union men in the Border States felt that any more effort to keep the peace and prevent bloodshed was useless." 22

Because Kentucky's business and family ties were linked tightly to the South and the Governor was an open Southern sympathizer who refused to supply any troops to suppress the rebellion, Harlan and other prominent Unionist Whigs began maneuvering to keep the state loyal. ${ }^{23}$ During May, June and July of 1861 Harlan and a few friends hired brass bands and, each afternoon, stood on store boxes on the pavements of Louisville telling everyone who would listen of the importance of Kentucky remaining in the Union. ${ }^{24}$ The threat of Confederate invasion led Harlan to join a home-guard unit formed by Unionists, as Captain of the Crittenden Union Zouaves. ${ }^{25}$ Other adventures followed, from his role in the smuggling of "Lincoln Guns" into Kentucky ${ }^{26}$ to a remarkable episode in which Harlan virtually took over the Louisville Journal

22. Autobiographical Letter at 9.

23. This story is told in detail in Speed, The Union CAUSe in Kentucky, 1860-1865 (1907) and Rev. Daniel Stevenson, General Nelson, Kentucky and Lincoln Guns, Mag. Am. Hist., Aug. 1883, pp. 115-39.

24. The Union Cause in Kentucky in 1861 and the Raising of a Regiment by Me for the Vohutecr Infantry Service. Some Incidents in that Service, 20 pp., at 2-3, Harlan Papers, Author's Possession (hereinafter cited as The Union Cause). Harlan wrote:

"During the summer of 1861 nothing was talked of in Kentucky except Union and Disunion. The courts were virtually closed, and there was but little business in my profession. We determined to defer decisive action until the Union men of the State obtained arms, and in the meantime educate the people as to the value of the Union and as to the horrors and dangers of a civil war, should Kentucky ally itself with the rebel forces. ... The thing we had in mind was to stay the tide then apparently setting towards the rebel cause, and to hold the people in line until the friends of the Government in Kentucky could strike effectively for the Union."

25. Some experiences as a Captain of Home Guards-the Crittenden Union Zonaves of Louisville, Kentuchy, in 1861.-Ammunition carried to Sherman on Muldraugh's Hill, 5 pp., Harlan Papers, Author's Possession.

26. The Union Canse, supra note 24, at 4-8. Fearing Confederate invasion or a Southern coup d'etat, Harlan arranged with the Union agent, William Nelson, to convey a shipment of "Lincoln Guns" past Confederate interceptors to the Union volunteers at Camp Robinson:

"The guns were shipped from Cincinnati to Louisville on the regular mail boat, which arrived at the Louisville wharf about two or three o'clock in the morning. I was at the wharf to receive them. Bullett was with me. We had them put on drays previously provided, and carried them across the City to the depot of the Louisville and Lexington Railroad .... Bullett and myself walking in the street by the side of the drays, each being well armed to resist any attempt to take the guns."

Id. at 6 . The Confederates did attempt to seize the guns at the depot and a pitched battle almost touk place between "Morgan's Men" and a Unionist company, but the arrival of 
from its editor and kept the paper from swinging to the Southern camp. ${ }^{27} \mathrm{By}$ the fall of 1861 Harlan realized he must "join the Volunteer Union forces and become something more than a speaker for the Union cause in public halls or on the stump." 28 Assured by his young wife, Mallie, that she would take care of the two children and he could "go to the front," 29 Harlan issued a proclamation announcing his intention to raise an infantry regiment and join the forces of General Robert Anderson. Calling for his fellow Kentuckians to join him, Harlan pleaded:

"Their invaded State appeals to them. Their foully-wronged and deeplyimperiled country appeals to them. The cause of human liberty and Republican institutions everywhere appeals to them. All that is most glorious in human government is now at stake, and every true man should come to the rescue. . . . Come, then, let us gird up the whole strength of our bodies and souls for the conflict, and may the God of Battles guide home every blow we strike. For one, I am unwilling to see the people of my native State overrun and conquered by men claiming to be citizens of a foreign government. I cannot be indifferent to the issue which an unnatural enemy has forced upon Kentuckians."30

\section{Mud, Bayonets and the Taming of an Aristocrat}

Commissioned at twenty-eight a Colonel of the 10th Kentucky Volunteers, under General George Thomas (the famous Virginia commander who cast his fortunes with the North), John Harlan saw action in Kentucky, Mississippi and Tennessee. His outmaneuvering of Morgan's Raiders at Rolling Fork Bridge in Kentucky during September of 1861 not only earned him a commendation from Brigadier General Speed S. Fry for saving the Union railway lines and breaking Morgan's hold on Tennessee, but also established him as something of a military hero at home in Kentucky. ${ }^{31}$

But for each of these skirmishes, there were miles of forced marches, days in which supplies failed to arrive and nights spent bivouacked in the cold rain. John Harlan's dispatches record these hardships, and at the same time reveal how deeply he was affected by these experiences. On several occasions his

four hundred cavalrymen from Camp Robinson, to protect the shipment, forced the Confederates to withdraw. Id. at 6-7.

27. History Made Behind the Scenes, Mrs. Harlan, Memories at 46-50.

28. Autobiographical Letter at 12.

29. Ibid.

30. Morning Louisville Democrat, Sept. 29, 1861; Oct. 9, 1861, Harlan Papers, Author's Possession.

31. Harlan's dispatches are printed in WAR of THE Rebellion: OfFicial Reconds of the Union and Confederate Armies, Series I, vols. 7, 16, 20, 23; Series III, vol. 1 (1882) (hereinafter cited as WAR of THE REBELLION); for general accounts of the battles in which Harlan participated see Duke, History of Morgan's Cavalry (1867); Jounson, A Soldier's Reminiscences in Peace and War (1886) ; Johnson \& Buel, Battles and Leaders of the Civil War (1884-1887); Speed, The Union Reginents of Kentucky (1897) ; Van Horne, History of The Ardiy of the Cumberland (1875) ; MrliTARY History of KENTUCKY, op. cit. supra note 20. 
dispatches contained pleas for additional shoes and socks or other clothing for his exhausted men. ${ }^{32}$ In reporting his victory at Mill Springs, Kentucky, in January of 1862 , Colonel Farlan wrote:

"Although the men of my regiment were entirely destitute of provisions, and on that morning had not received half enough for breakfast, my summons to them to fall in line and march to the aid of our brethren was obeyed with commendable alacrity. ... I took possession of the woods immediately in front of the rebel fortifications, with directions to hold against any attack of the enemy. There my men lay on the ground during the whole of Sunday night without fire, tents, overcoats, or blankets, and with nothing to eat except about one-fourth of a cracker to each man."33

Of the Cumberland campaign, Harlan later wrote:

"The route to Mill Springs was over a dirt road, and the earth was so thoroughly soaked with rain that Thomas's troops could only make a few miles each day. The regimental wagons sank into the earth up to the hubs of the wheels, and had to be lifted out by the soldiers. There was not a day when I did not myself join in that work in order to encourage my men. All along the route we had to cut down trees and saplings and make what were called 'corduroy' roads, over which the wagons, when lifted out of the mud, would be placed by the soldiers." 34

Harlan's close contact with the German immigrants and Kentucky mountaineers of his regiment and his respect for their soldierly devotion led the young scion of Ashland to write glowingly in his dispatches of his men's "willingness, even eagerness, to endure any fatigue or make any sacrifice ...."35 In later years, this bond with the men who wielded the bayonets buttressed Harlan's egalitarian instincts. "When war menaced the country," Harlan observed, "it was the poor and sons of the poor who sprang to its defense," 36 and who "deserve the thanks of the country for the cheerfulness with which, with insufficient food and rest, they bore up under the severest privations. . . ."37 Also, the qualities of men as men were brought home to Harlan, to wash away the nativistic aspect of his antagonism to Catholics and immigrants. Writing of the "many Catholics in my regiment," Harlan noted:

"It was a magnificent sight to see how the boys struggled through mud and rain to reach the field of battle. The ground was so wet and muddy under them that their feet slipped at every step. I see now with great distinctness old Father Nash pushing along on foot with the boys. Equally earnest with him was a Catholic priest from Washington county, who had come with Catholic soldiers from that county."38

32. War of the Rebelioion, Series I, vol. 16, pt. 2, at 236, and Series I, vol. 20, pt. 1, at 136 .

33. Id., Series I, vol. 7, at 89 .

34. The Union Canse, supra note 24, at 11-12.

35. WAR of the Rebeliton, Series I, vol. 7, at 90.

36. Cincinnati Daily Gazette, June 28,1871 , Hartz, supra note 12 , at 27.

37. War of the Rebellion, Series I, vol. 20 , pt. 1 , at 140.

38. The Union Cause, supra note 24 , at $12-13$. The camaraderie Harlan achieved with 
In February of 1863, Colonel Harlan learned that his father had died suddenly of a congestive chill. Because he alone could handle his father's business and support his mother and family, Harlan was forced to retire from military service. ${ }^{39}$ But fearing that his motives might be misunderstood, because he was from a slave slate, ${ }^{40}$ Harlan stated his reasons in his letter of resignation:

"I deeply regret that I am compelled at this time to return to civil life. It was my fixed purpose to remain in the federal army until it had effectually suppressed the existing armed rebellion and restored the authority of the national government over every part of the nation. No ordinary considerations would have induced me to depart from this purpose. Even the private interests to which I have alluded would be regarded as nothing, in my estimation, if I felt that my continuance in or retirement from the service would to any material extent affect the great struggle through which the country is now passing.

"If, therefore, I am permitted to retire from the army, I beg the commanding general to feel assured that it is from no want of confidence either in the justice or the ultimate triumph of the union cause. That cause will always have the warmest sympathies of my heart, for there are no conditions upon which I will consent to a dissolution of the union. Nor are there any conditions consistent with a republican form of government which I am not prepared to make in order to maintain and perpetuate that union ... ."

his men is illustrated by a recollection of Champ Clark, who grew up in the part of Kentucky from which Harlan's regiment was raised:

"When the soldiers came back from the war they had divers tales to tell of their beloved colonel. Among other things they said he could outrun, outjump, and outwrestle any man in the regiment. They told, with great glee how, before they were ever in battle, the colonel would make them speeches about how bravely they should perform under fire, and how, after their first engagement-the battle of Mill Springs -the colonel told them frankly that if any of them felt like running he did not blame them, for all that prevented him from fleeing was his shoulder-straps."

1 Clark, My Quarter Century of Amrerican Politics 64-65 (1920).

39. Autobiographical Letter at 30-31; Civil War-1864. My Father's Death and My Resignation as Colonel of the Tenth Kentucky Infantry, March 2nd, 1863 . ., 4 pp., Harlan Papers, Author's Possession. He said:

"This was, on every account, an unspeakable calamity to the family. ... At the time he died my father had the largest practice of any lawyer in Kentucky and the support of my Mother and the family depended on the right handling of the business left by him. My three oldest brothers were dead, and my only remaining brother had become incompetent for business. I was connected with my father in business and alone knew of what was necessary to be done in order to preserve from loss or waste what he had fairly earned by hard work in his profession. So, in every just sense, I was compelled to return to civil life. This was the view of all my brother officers, including Gen. Rosecrans and his Chief of Staff, Gen. James A. Garfield."

40. According to J.M.H. to Senator James B. Beck, Oct. 31, 1877, Records of the Forty-Fifth Congress, Judiciary Committee, United States Senate, National Archives, Washington, D.C. The letter is reprinted in Document: The Appointment of Mr. Justice Harlan, 29 IND. L.J. 46, 60-68 (1953) (hereinafter cited as Document).

41. Harlan Papers, Author's Possession. 
After receiving a testimonial from his regiment, ${ }^{42}$ Harlan returned to Louisville and civilian life in March of 1863 . His retirement did not mean a complete disengagement from service, however, for during the entire war Kentucky stood in a constant state of invasion, occupation and unease. In the fall of 1864, for example, Harlan took a prominent part in defending Frankfort against a guerilla raid led by Confederate General John H. Morgan. ${ }^{43}$

\section{Walking a Middle Road}

Harlan arrived in Kentucky just as the state election campaign of 1863 was about to begin. The Kentucky Unionists approached him immediately and asked him to accept the nomination for attorney general. "The suggestion was not disapproved by me," Harlan wrote, "principally because if elected I would be required to remove to the capitol of the State where my father lived at the time of his death, and where I was compelled to be in order to wind up his business and estate." 44 Harlan was nominated and he joined the Kentucky Unionists in making the "dangerous policies" of President Lincoln the dominant issue of the campaign. Defending slavery and constitutional liberty at the same time, Harlan attacked Lincoln's promulgation of the Emancipation Proclamation and his suspension of the writ of habeas corpus, in keeping with Harlan's later observation that "the Kentucky Unionists, as a general rule, did not approve of all the methods suggested by the Union men of the Northern States for the prosecution of the war, particularly those relating to the institution of slavery." 45 This note was exactly right as far as political sentiment in Kentucky was concerned. With Federal troops policing the election, the Union Party trounced the Peace Democrats, John Harlan receiving a 50,000 majority over his opponent. ${ }^{46}$

Harlan's activities during his four-year term as attorney general were multifold. Since the job was a part-time one, he maintained an active law practice, first with his brother James and then alone, appearing in the state and federal courts, particularly in the matter of claims against the United States and Kentucky governments.47 "Special attention," the professional card of Harlan

42. The resolutions expressed the officers' confidence in Colonel Harlan's "courage, skill and genius, and in his unswerving devotion to the cause of the Union. . . " They also stated that, during Harlan's eighteen months as a unit commander, "he has won the love and esteem of his whole command, by his amiable manners, unflinching integrity, and his indefatigable attention to all his duties. ..." Resolutions passed by the officers of the Second Brigade, Third Division, 14th Army Corps, at a meeting held for the purpose of expressing their feelings upon the occasion of the impending departure of Col. John $M$. Harlan ... , Harlan Papers, Author's Possession.

43. Raid by Morgan's Men on Frankfort, Kentucky, in the Fall of 1864, 3 pp., Harlan Papers, Author's Possession.

44. Autobiographical Letter at 31.

45. Id. at 11 ; see Harts, supra note 12, at 28 .

46. See Coulter, op. cit. supra note 20 , at 170-79.

47. In Kentucky the attorney general was permitted by local custom to retain his private law practice. 
\& Harlan announced, will be "given to the collection of pay for slaves enlisted, or drafted into the Army. We have facility for this business here where indispensable evidence is on file. . ."48 During this period he was also busy settling his father's estate, selling property and arranging the disposition of family possessions.

As attorney general, Harlan argued over sixty appellate cases for the Commonwealth, including several cases involving slave issues and civil rights. In Jones v. Commonwealth ${ }^{49}$ the Kentucky Court of Appeals accepted Attorney General Harlan's contention that a federal provost marshal could not take private property (e.g., a Negro woman slave and her three children) without a showing of immediate danger or necessity to the national government and that the removal of the slaves from the state by the marshal was an indictable offense under Kentucky law. In Commonwealth v. Palmer 50 Harlan contended that the Commanding Union General in Kentucky, John M. Palmer, has been guilty of the crime of aiding slaves to escape when he ordered train and ferry owners to permit colored persons with military passes to leave Louisville; the court agreed with Harlan and found General Palmer, who had left Kentucky by then, to be indictable for the offense.

In the case of Bowlin v. Commonwealth ${ }^{51}$ a lower court, following the Federal Civil Rights Act of 1866, had allowed the introduction of Negro testimony against a white defendant indicted for larceny, despite a Kentucky law forbidding Negro testimony against white persons. True to his strong convictions and his political position, Harlan filed a special "Suggestion for the Commonwealth" that declared:

"The only question on this appeal is as to the propriety of the court admitting the testimony of a negro against a white person. Not feeling at liberty, according to my views of that question considered as a legal proposition, to uphold the judgment of the court below, the case is respectfully submitted to the court without argument on behalf of the Com'th."

The Kentucky Court of Appeals, sharing Harlan's views, reversed the conviction with the declaration that, despite the anarchy which had reigned in Kentucky during the previous years, the Constitution of the United States was now restored to effect and its provisions as to the rights of the states to prescribe the rules of evidence in their own courts forebade any congressional meddling with Kentucky's law on Negro testimony.

48. Frankfort Commonwealth, Feb. 22, 1867, the card having appeared in each edition of the paper since March 16, 1863, Harlan Papers, Author's Possession.

49. $64 \mathrm{Ky}$. (1 Bush) 34 (1866).

50. $65 \mathrm{Ky}$. (2 Bush) 570 (1866). For the background of this case, which was a cause célebbre in Kentucky and Harlan's most important prosecution, see PALArER, PERSONAL Recollections of John M. Palmer; The Story of an Earnest Life (1901); George T. Palmer, A Consctentious Turncoat, The Story of John M. Palmer, 1817-1900 (1941) ; Coulter, op. cit. supra note 20, at 264-89.

51. $65 \mathrm{Ky}$. (2 Bush) 5 (1867).

52. Record, Bowlin v. Commonwealth, supra note 51, Archives of the University of Kentucky, Lexington. 
These cases highlight Kentucky's peculiar plight as a loyal state which found itself occupied by Northern troops and at times under full martial law, a state which saw emancipation doctrines pressing steadily toward the freeing, without compensation, of the slaves of Kentucky Unionists. The results were a deep bitterness on the part of even the most devoted Unionists in Kentucky and a general atmosphere of public hostility to federal measures which made any political support of Lincoln and the national Republican Party impossible. It was natural that John Harlan should support General George McClellan in the presidential race of 1864 and that the speeches he made in Kentucky and Indiana would be against the Lincoln Administration. One speech, delivered at New Albany, Indiana, on October 4, 1864, deserves reproduction at length, since it expresses so well Harlan's complicated perspectives in the final months of the Civil War.

"Colonel Harlan," the report opened, "took the stand and delivered one of the best speeches of the campaign." and Indiana and his deep desire to see their political destinies follow the same course, Harlan gave a comprehensive review of the issues in the 1864 election.

" $\mathrm{He}$... alluded to the contest of 1860 , resulting in the election of Abraham Lincoln as President-an event which, while it afforded no occasion for the dissolution of the Union, gave an opportunity to bad men of both sections to excite sectional feeling and disrupt the Union. That party [the Republican] should never have triumphed, because it was based upon the single idea of hate and hostility to the social institution of one section of our country; its candidate having been elected in accordance with the Constitution, he was entitled to be respected as President.

"The disunionists of the South, however, were not content to await the slow processes of the ballot box. They fired upon the flag of the United States and then aroused the entire people of the North, including those who have felt and believed that the Abolitionists could have averted the terrible calamity of civil war had they been actuated by that spirit of conciliation and compromise in which the Constitution was framed by our Fathers.

"But for what purpose did the people of the North rise as one man? It was to maintain the Union, and the Constitution which was the only bond of that Union. It was for the high and noble purpose of asserting the binding authority of our laws over every part of this land. It was not for the purpose of giving freedom to the negro. . . .

"Mr. Lincoln has in disregard of the then declared purpose of the nation changed and perverted the character of the war. He is warring chiefly for the freedom of the African race. He will not be content with simply re-establishing the authority of the Constitution and restoring the union."

Lincoln's plans, Harlan felt, made the war interminable, earned hatred for the Union from the people of the South, and prevented the rise of "a peace party in the South." Harlan went on to declare:

53. The New Albany speech appears in the Harlan Papers, Author's Possession, in typescript copy of what was obviously a newspaper report of the talk. The same report appears in Greshanr, LIfe of WaLter Quintin Greshani, 1832-1895, vol. II, app. B at 823-25 (1919). 
"The triumph of abolition would be the triumph of a spirit which in order to effect its purpose would not hesitate to trample upon constitutions and laws with impunity. There is no safety in this land of ours except in rigid adherence to law-no safety for life, liberty, or property. [General McClellan is] . . . the representative of that spirit of conservatism that respected the Constitution and the laws. . . . He would never consent to a dissolution of the Union, but if elected would so exert the power of the nation as to give us peace-peace with an unbroken Constitution, peace upon the basis of the Union of our fathers.

"Lincoln commenced with a united North and a divided South. He now has a divided North and a united South. ... An Abolitionist is for the Union on condition that slavery is abolished. A Secessionist is for the Union-if at all -only on condition that slavery is preserved."

For himself, Harlan said, "he was an unconditional Union man, unconditional for the Union and the Constitution."

In 1864 Harlan had several personal transactions dealing with slaves, the first arising out of the settling of his father's estate. As Mallie Harlan described the incident in her memoirs:

"Under the law, my husband's mother, who was his idol, was entitled only to one third of her husband's estate. She had always had ten or twelve slaves at her command, and my husband felt that it would have been cruel to leave her with the few servants that would ordinarily have fallen to her in the division of the Estate. In addition to the feeling he had as to her comfort, my husband, having been brought up with those servants in the peculiarly close relations that existed between Master and slaves in the case of the best type of Slave-holders in the South, had a real affection for his father's servants. He could not bear to think of them falling into other hands through the barter and sale of human beings that was still in vogue. Promptly, and without a thought of himself and the burden he would have to carry, he therefore made himself responsible to the Estate for the value of the rest of those slaves, and he actually paid for them after Lincoln's Emancipation Proclamation [probably, this means after the Thirteenth Amendment] had set them free." "פ4

In 1864, for the first time, Mallie and John set up housekeeping on their own, and, for domestic help, they bought a Negro cook from "a certain young couple who were leaving Kentucky, and who felt sure that freedom for the slaves was near at hand. ..." Difficulties in the kitchen between "Aunt" Fannie and the young Mrs. Harlan resulted in the Harlans giving the woman her freedom and replacing her with "Aunt" Charlotte, a woman who begged the Harlans to buy her so that she would not be "sold South" and separated from her husband. ${ }^{55}$ These represented Harlan's only personal experiences as a slave owner.

\section{The Middle Road Vanishes}

Between 1865 and 1867 Harlan was a leader of the Conservative Union Party, a middle-of-the-road group which tried to steer a course between the

54. Mrs. Harlan, Memories at 56.

55. Id. at 59-61. 
two major groups in Kentucky, the Democrats (Confederates) and the Radicals (supporters of President Johnson's administration). The Conservatives, whose leaders were the same Whig-Americans who tried to attack both abolitionists and secessionists in the years just before the Civil War, tried to strike the same type of compromise position. In the 1865 elections for state legislature, the dominant issues were the Thirteenth Amendment and Reconstruction policy in Kentucky, and on these issues, the Conservatives swung close to the Democratic side. ${ }^{.6}$ Harlan made a series of speeches in which he condemned General John Palmer for enlisting large numbers of Negroes to effect their emancipation, since this resulted in the creation "of large bodies of negro men, women, and children in this State, [living] at the expense of the Nation and [receiving] a watchful care which has never been exhibited for the wives and families of white soldiers of Kentucky." The operation of the Freedman's Bureau and federal coercion of the state authorities was attacked by Harlan, who predicted only chaos from the situation in which the State is denied the power "to effect the removal of the blacks to other localities or protect her white citizens from the ruinous effects of such a violent change in our social system." In times like these, Harlan wrote to a fellow-Conservative, there had to be "a thorough union of all citizens who . . . are opposed to the admission of the negro to the ballot-box or to the enjoyment of other political advantages." 57 As far as the Thirteenth Amendment was concerned, Harlan supported the Kentucky Legislature's failure to ratify that instrument, saying that he adopted his position on principle and would maintain it "if there were not a dozen slaves in the State of Kentucky. ..."5s For Harlan, the Thirteenth Amendment embodied dangerous principles; not only did it represent "a flagrant invasion of the right of self government" and a breach of promise to the loyal slave-holders of Kentucky, ${ }^{69}$ but it also gave to "a bare majority in Congress" the power to wipe out property rights guaranteed by the American Constitution." As in 1861, Harlan affirmed that he remained "opposed to the dissolution of the Union in any event," and he tried to suggest a compromise solution to the slavery issue, offering the proposal that Kentucky itself should undertake a gradual abolition of slavery over the next seven years. ${ }^{61}$

The Democrats scored a solid victory in the 1865 elections. The following year the Conservatives swung into an alliance with the Radicals, the two parties supporting E. H. Hobson, a distinguished Union General, as their joint gubernatorial nominee. ${ }^{62}$ As the exultant Democrats hammered away in the 1866 canvass at this uneasy coalition, and Radical policies in Washington grew even more distasteful to Kentuckians, many of the Conservatives (including

56. See Coulter, op. cit. supra note 20 , at 257-84.

57. Letter from J.M.H. to Col. John Combs, published in the Lexington Observer and Reporter, June 1, 1865, Hartz, supra note 12, at 29.

58. Cincinnati Gazette, Aug. 2, 1865, id. at 30.

59. Cincinnati Gazette, July 7, 1865, quoted in Coutrer, op. cit. supra note 20, at 279-80.

60. Lexington Observer and Reporter, June 1, 1865, Hartz, supra note 12, at 30.

61. Letter to Combs, supra note 57.

62. CoulTer, op. cit. supra note 20, at 303-11. 
Harlan) pulled away from Hobson and spent their time attacking Northern measures. With the Thirteenth Amendment having been ratified by threefourths of the States and placed in the Constitution, Harlan and the Conservatives set out to hold the line at this point. "The permanent triumph of those who in the North are following the lead of Sumner and Stevens in their series of Constitutional Amendments," Harlan charged, "would work a complete revolution in our Republican system of Government, and most probably the overthrow of constitutional liberty." The aim of these Radicals, he said, was "by amendments to the Constitution and laws of Congress to disenfranchise almost the entire white population of the insurrecting States and to enfranchise the negroes. ..."63 At the same time, Harlan lashed out at the "Disunionists of 1861," noting that the Conservatives denounced "the heresies of secession and rebellion" no less than they "denounced the fanaticism of the North."64

Again the Democrats swept the polls, this time by a 38,000 vote margin over the combined Radical-Conservative ticket; the victory, one newspaper wrote, was a triumph of grey over blue. ${ }^{65}$ The leaders of the Conservative Party met in Frankfort in March of 1867 , surveyed their failure, and emerged with a reconstructed movement they dubbed the Conservative Union Democrats. or "Third Party." The manifesto of the new party announced that it was the real Democratic party in Kentucky, standing against the usurpations of Congress and the divisive efforts of the Confederates, and John Marshall Harlan was the party's nominee for attorney general. The regular Kentucky Democrats were not impressed by this name-stealing, however, and they went on to pile up smashing victories in both the congressional and state elections of 1867.66 The fact was, as the Cincinnati Weekly Gazette had observed, "There are but two parties in Kentucky. You must go to the one or to the other. . . If you choose to attempt a middle party, well and good. In some places the rebels will beat you ; in others, the Radicals." 67 This comment was so clearly proved by the 1866 and 1867 elections that, in the winter of 1868 , the Conservatives simply folded up. Most of them, encouraged by overtures from the Democrats and promises that the Union cause would be honored, went over to the Democratic Party. Only a small group, men like James Speed, W. H. Wadsworth and John Marshall Harlan chose the other road.

\section{The Making of a Republican}

Harlan's conversion to Republicanism was the most significant political choice he ever made, leading as it did to his eventual appointment to the Su-

63. Louisville Courier-Journal, June 3, 1871, Hartz, supra note 12, at 31.

64. Cincinnati Commercial, July 20, 1866, ibid.

65. Coulter, op. cit. supra note 20 , at 309.

66. Id. at 320-26.

67. Cincinnati Weekly Gazette, March 21, 1866, Hartz, supra note 12, at 32. Harlan felt that the 1867 elections "made it certain that the continued separate organization of our party' could not accomplish anything, in political matters, of a practical nature, or exert any influence upon the conduct of public affairs." Political Memorandım, supra note 11, at 13. 
preme Court. Actually, it was a choice that he drifted to rather than made freely.

The resounding defeat of the Conservatives in 1867 convinced Harlan that a third party could accomplish nothing in Kentucky. Bred in the tradition that no honorable man was without a party affiliation and living in an era when the practice of law was inescapably intertwined with politics, Harlan began to consider a new political allegiance. At just this moment, he moved from the fiercely anti-Negro and pro-Democratic stronghold of Frankfort to the more cosmopolitan city of Louisville, which lay close to the staunch Republican stronghold of Indiana. When he opened his law office in Louisville, Harlan's closest contacts were with the leading Radicals, primarily because much of Harlan's attention in 1867 and 1868 was with the split in the Kentucky Presbyterian Church. As a devoted and active Presbyterian layman, Harlan had endorsed the pro-Union position adopted during the war by the General Assembly of the Presbyterian Church in the United States. In 1866, in keeping with the post-war swing of Kentucky sentiment to the Southern cause, a revolt took place among Kentucky Presbyterians, and a majority of the communicants, headed by the Democratic Party leaders, broke away from the national church and from the uncompromisingly pro-Union leadership of the dominant figure in the Kentucky church, Rev. Robert J. Breckinridge. Harlan became a leader of the Northern group. In 1867 the Southern group tried to seize control of Centre College by means of a bill in the Kentucky Legislature putting the College under the jurisdiction of the Southern Synod. John Harlan was chosen to present the case against the bill to the Judiciary Committee, and, through his efforts, the Breckinridge group managed to kill the measure. Harlan was also the counsel for the Breckinridge faction in several bitter court fights in which the Southern adherents tried to win title to church property held by proNorthern congregations. For Harlan the result of these religious conflicts was to add the stain of heresy and schism to the Southern-Democratic cause and to make allegiance with the Southern leaders impossible. His closest friends and legal associates were now Northern-Presbyterian, pro-Radical figures such as the Federal District Attorney for Kentucky, G. F. Wharton, Federal District Judge Brand Ballard, General W. C. Goodloe, and the influential Benjamin Bristow, with whom Harlan soon entered into a law partnership. ${ }^{68}$

Specifically on the political front, it had become clear by 1868 that only the Republican and Democratic parties were available in national politics and that the same two-party pattern was beginning to emerge in Kentucky after the decade of confused multi-party politics through which Harlan had just passed. At both state and national levels Harlan found himself simply unable to

68. Coulter, op. cit. supra note 20, at 394-99; Speech of John M. Harlan, Before the Committce on Judiciary, Frankfort Commonwealth, Feb. 22, 1867, Harlan Papers, Author's Passession; Second Presbyterian Church Case, Correspondence of John M. Harlan, ibid.; J.M.H. to Robert J. Breckinridge, Dec. 5, 1866, Brechinridge Papers, Library of Congress; J.M.H. to Benjamin Bristow, Oct. 6, 1871, Mar. 21, Apr. 15, Apr. 16, 1872, Bristow Papers, Library of Congress. 
stomach the Democrats. Reflecting on this later, Harlan recalled, "I was an intense Nationalist," and the "great majority of the Democrats in Kentucky believed that their first allegiance was to the State. . .." Nationally, Harlan concluded that "the general tendencies and purposes of the Democratic Party were mischievous, while those of the Republicans were the better calculated to preserve the results of the War. ..."69 Harlan's choice was made easier when Ulysses S. Grant was chosen as the Republican standard-bearer. General Grant had been an acquaintance of Colonel Harlan during the war; he stood for defense of the Union victory against the resurgent forces of the secessionist democracy; and he was unconnected personally with the struggles over the War Amendments and reconstruction. By this time Harlan had come to feel that accepting the War Amendments as a fait accompli was the sensible course to adopt if Kentucky and the South were to move forward economically and socially in the post-War decades. Thus the autumn months of 1868 found Harlan campaigning in Kentucky for General Grant and in Indiana for the Republican Governor, Oliver P. Morton. In both places, his main attack was on the Democratic Party for its ante-bellum intransigence. Significantly, during his speeches, he defended the Republican Party for having sponsored the Thirteenth and Fourteenth Amendments.

Between 1868 and 1871 Harlan plunged happily into law problems in his new firm of Harlan, Newman \& Bristow. He also took hold of the newlyformed and still overwhelmed Republican Party of Kentucky, corresponding extensively with party leaders throughout the state and carrying his personal following from Conservative Party days into the new organization. The most important development he pondered during this period was the impending enfranchisement of the Negro, and what this meant for Republican Party hopes in Kentucky. As the leading historian of Kentucky during reconstruction has written,

"It was the negroes on whom the Radicals now began to pin their faith for ultimate victory. . . . It was predicted that there would be 100,000 negro voters; and with considerable elation the Louisville Commercial [a leading Republican paper] declared that elections thereafter would not be 'the one-sided affairs of 1867,1868 , and 1869." "70

The Republicans set out to attract the new voters, holding picnics and organizational meetings and stressing the indebtedness of the Negro to the party of "Honest Abe" and Charles Sumner. The first real test of Negro strength at the polls, apart from a premature contest in 1870, was the election of state officers in 1871. The Republicans, anxious to present a fresh candidate, chose John Marshall Harlan as their gubernatorial nominee and party leader. $\mathrm{He}$ later observed:

"I did not seek the nomination [and] ... had no thought of it; for my purpose was to stick closely to the practice of my profession and make an estate for my young family. But that nomination seemed to be a call to

69. Political Memorandum, supra note 11 , at 14.

70. Coulter, op. cit. supra note 20 , at 422 . 
duty, and I accepted it, knowing that I could not be elected. . . . Determining to do all I could to organize the Republican Party of Kentucky, and to make the best fight possible, I started in the campaign in the latter part of May and went into every county in the eastern part of the State and most of the other counties, the journey being made on horseback."71

Harlan's leadership of the Republicans provided " $[t]$ he real beginning of an intelligent opposition to the Democrats ... and it can be truly said that the Republican Party in Kentucky was born [in 1871]."72 Harlan championed a comprehensive program for the expansion of the Kentucky economy and thundered at the Democrats for choking the State's growth by their continued backward perspective and race hatred. ${ }^{73} \mathrm{He}$ struck out at the Democraticsupported monopoly of the Louisville \& Nashville Railroad over transportation facilities in Kentucky and urged the voters to back Republican plans to franchise a line of the Cincinnati Southern Railway. His speeches were filled with pleas that Kentucky should build up "rivals" to the Louisville \& Nashville monopoly "and every other monopoly in this commonwealth."74 Harlan warned that monopolies not only "stifled the powers of industry and national health" but had the effect of "absorbing the capital of the state and controlling its politics."7s The Democrats replied by branding the railway bond proposal as a scheme to run up a huge "Radical rule" debt and " do' the people of Kentucky out of forty or fifty millions," as had been done in Louisiana under the Republicans. ${ }^{70}$ Harlan also came out for a state-sponsored program of inviting immigrants to Kentucky, from Germany and other countries of Europe, so that the state's rich "agricultural, mineral, and manufacturing resources may be developed."77 But when Harlan attacked the Democratic Legislature for failing to assist with funds a German-immigration society and for driving immigration "to other states,"7s the Democrats came to the debating platforms carrying clippings of Harlan's speeches in the 1850's attacking foreigners and opposing any further immigration; and the Democrats continued to read Harlan's "Inow-Nothing scripture" throughout the campaign." Another theme developed by Harlan was a plan to substitute an income tax for the Democrats' property tax as a means of paying the Civil War debt of the State. The Democratic policy, he explained to voters, taxed "your farms, houses, land, implements, and tools" at the same level that it taxed "the incomes . . . of the wealthy." In place of this, Harlan proposed the federal tax system; the Congress, realizing "that the poor man would have to fight the battles of the
71. Political Memorandum, supra note 11, at 15.
72. Coulter, op. cit. supra note 20 , at 433.
73. Id. at 434-37; Harta, supra note 12, at 36-39.
74. Cincinnati Daily Gazette, May 24, 1871, id. at 37.
75. Louisville Daily Commercial, July 29,1871 , $i b i d$.
76. COULTER, op. cit. supra note 20, at 436-37.
77. Louisville Daily Commercial, May 18, 1871, Hartz, supra note 12, at 36.
78. Louisville Courier-Journal, May 31, 1871, ibid.
79. Louisville Courier-Journal, May 28, 1871, ibid.
80. Louisville Daily Commercial, July 29,1871 , id. at 38. 
country ... determined to make the rich man pay the taxes. . . The lawyer and the physician were taxed on their income over and above $\$ 2000$, but the poor mechanic who only made $\$ 1000$, or $\$ 1500$, a year was not taxed on his income at all."81 Coupled to his income tax proposals, Harlan urged that in place of the new state law which raised school deficits by assessing local families in proportion to the children they enrolled in school, there should be a general property tax for school maintenance. Praising the poor men who had fought courageously in the Civil War, Harlan said that "the rich owed it to the poor to contribute to the education of the latter."

Harlan's turn to anti-monopoly and neo-Jacksonian issues seems to have been caused not simply by the rise of strong Granger and populist sentiment in Kentucky, but also by an interest which he developed in the early 1870's in the future of the Kentucky mountaineers, men he had grown to know and respect in his Civil War regiment. Mrs. Harlan noted in her memoirs that during the 1871 and 1875 campaign, "The sturdy mountaineers, in particular, became a most interesting study to him. He predicted a great future for them, because of the opportunity for education that was then opening to them and the new ambition that seemed then to be stirring in them." 82

However important the new issues of the 1871 campaign proved to be in shaping the economic philosophy of Mr. Justice Harlan, the issue which overrode everything else in that campaign was the Negro question. For the Democrats, civil rights was the rallying cry by which they would keep their antiNegro coalition together; for the Republicans, the new Negro voters represented the only chance, as a matter of strict arithmetic, to break Democratic hegemony in Kentucky. In the three years since his move into the Republican Party, Harlan had been forced to reconsider his attitude toward the civil rights problem. The War Amendments whose ratification he had opposed were now a part of the Constitution of the United States and their repeal was impossible to visualize. In the eyes of the fundamental law, Negroes were no longer chattels like horses and houses but were human beings, entitled to every right of a free American given by the supreme law of the land. To some Southerners, this investing of the mass of uneducated Negro slaves with civil rights was a call to violence against the law or to the beginning of a cynical evasion of the Amendments. To Harlan, however, a man who held the Constitution alongside the Bible as a document to which unswerving allegiance was owed, and who believed there was "no safety in this land of ours except in rigid adherence to the law,"83 the adoption of the War Amendments could not be brushed off that easily. Perhaps grudgingly at first, perhaps with the feeling that too much had been done too fast, Harlan began to look realistically, with a constitutional

81. Louisville Courier-Journal, May 31, 1871, ibid.

82. Mrs. Harlan, Memories at 67 . A study of the voting statistics during this period shows that the Republican vote was made up almost entirely of the mountaineers of Eastern Kentucky, a sprinkling of "Old Jacksonian Democrats" in the same area, and the newly enfranchised Negro voters. See SHannon \& McQuown, op. cit. supra note 14, at 41-51.

83. See New Albany Speech, supra note 53. 
perspective, at the needs of reconstructing the Union and at the position of the Negro in Kentucky. Slavery was ended, Negroes were working for wages or in trades and were going to schools; Negroes were looking about for a party in Kentucky to which they could give their allegiance, and they were going to be full voters, with a ballot equal in weight to that of any white man. Most important, the continued agitation of the secessionists and irreconcilables to repeal the War Amendments had encouraged elements in Kentucky to take the law into their own hands. As Professor Coulter has described the scene, "Calling themselves 'Regulators,' 'Rowzee's Band,' 'Skagg's Men' and various other names, bands of men set about a veritable reign of terror in various parts of the state." 84 Any white man who incurred the displeasure of the bands could expect sudden death. The main effort of the bands, of course, was directed at Negroes:

"In the course of a few days lynch law ran riot on negroes charged with rape in Bardstown, Frankfort, and Owensboro; 'Skagg's Men' raided twenty negro houses near Lebanon and robbed and maltreated the occupants; a mob removed a negro from the Danville jail and hanged him in a graveyard; the 'Regulators' hanged two negroes in Washington County; ... 'Regulators' grotesquely garbed broke up a religious meeting of negroes, shot one and beat many. Thus the story went. In western Kentucky, the 'Regulators' gave notice to the negroes to leave the county and warned landowners not to rent to negroes on the peril of having their houses burned."85

In the county where the state capital was located, terrorists drove away fortyfour of the forty-five Negro voters who tried to vote in 1870 in one precinct, raided homes of Negroes and shot or whipped Negroes throughout the county. ${ }^{86}$

Perhaps more than anything else, the lynchings, floggings, robberies and terrorizing which swept through Kentucky between 1868 and 1871 and the failure of the Democratic Administration to control this, made Harlan re-examine his ideas and convinced him that the only way to bring peace was to accept the results of the War, recognize the legal rights of the new freedmen, and end the reign of violence, even if it took federal intervention to do the job. By the time of the 1871 campaign, it was a new Harlan that mounted the platform to give his views on the "Negro question." Addressing a rally in Livermore on July 26th, Harlan announced that he gave wholehearted support to the War Amendments and Negro civil rights:

"It is true fellow citizens that almost the entire people of Kentucky, at one period in their history, were opposed to freedom, citizenship and suffrage of the Colored race. It is true that I was at one time in my life opposed to conferring these privileges upon them, but $I$ have lived long enough to feel and declare, as I do this night, that the most perfect despotism that ever existed on this earth was the institution of African slavery.

84. Coulter, op. cit. supra note 20 , at 359.

85. Id. at 360 .

86. JoHnson, op. cit. sutpra note 11 , at 176 . 
It was an enemy to free speech; it was an enemy to good government; it was an enemy to a free press.

"The time was, and not long ago in Kentucky, when any declaration, such as I now make, against the institution of slavery, would have imperiled my life in many portions of the State. With slavery it was death or tribute. It knew no compromise, it tolerated no middle course. I rejoice that it is gone; I rejoice that the Sun of American Liberty does not this day shine upon a single human slave upon this continent; I rejoice that these human beings are now in possession of freedom, and that that freedom is secured to them in the fundamental law of the land, beyond the control of any state.

"It seemed wise to the majority of the people of this nation, not only to secure them their freedom in this way, but also to secure them the rights of citizenship, and the rights of suffrage; and I am now thoroughly persuaded that the only mode by which the nation could liberate itself from the conflicts and passions engendered by the war in connection with the institution of African slavery was to pass these Constitutional Amendments, and to place it beyond the power of any State to interfere with or diminish the results of the war now embodied in these Amendments. They are irrevocable results of the War; and because the Republicans of the State of Kentucky now acquiesce in those Amendments, or now declare them to be legitimate and proper, it is not just or candid to charge them with inconsistency.

"Let it be said that I am right rather than consistent."87

Turning the debate back upon his Democratic opponents, Harlan asked:

"What do these Southern-rights leaders hope to accomplish by agitating the repeal of the Fourteenth and Fifteenth Amendments? What do they mean by not only declaring these Amendments, but the Thirteenth Amendment were procured by force and fraud, and consequently are null and void? Do they suppose that it is in their power to take away from the colored people their freedom, their rights of citizenship or their rights of suffrage?... What good can come to the people of Kentucky, or any part of this country, by reopening in the various States of this Nation the question as to whether these colored people shall be free citizens or voters?"88

Harlan's new civil rights position included several direct attacks on the Democrats for their opposition to civil rights measures. Defending the Federal Civil Rights Act of 1866 and condemning the failure of the Kentucky Legislature to allow Negro testimony in the state courts, Harlan explained:

"Had the Federal Government, after conferring freedom on the slaves, left them to the tender mercies of those who were unwilling to protect them in life, liberty and property, it would have deserved the contempt of freemen the world over. It was due to humanity that some effort should be made to counteract the unjust and cruel policy which excited outrages upon their lives, liberty and property, and closed the courts against all

87. Quoted in summary of Harlan's campaign statements on civil rights in the 1871 and 1875 elections, General Harlan's Repnblicanism, Louisville Daily Commercial, Nov. 1, 1877, 16 pp. typewritten copy, Harlan Papers, Author's Possession at 4-5.

88. Id. at 5. 
remedy for such offenses, except where the proof [came from white witnesses]...."89

Harlan went on to condemn the bands of Regulators and Klansmen who were terrorizing Kentucky, and he attacked the Democratic Administration for failing to take strong measures to halt the breakdown of order:

"For myself, I say that I have no terms to make with that band of murderers and assassins, denominated $\mathrm{Ku} \mathrm{Klux}$; Nor shall I have any terms to make with them, if I shall have the honor to become the Chief Magistrate of the Commonwealth; Nor has the Government of the United States any terms to make with them. If they cannot be reached in any other way,

89. Id. at 5-6. There were four civil rights acts passed by Congress in the decade following the Civil War, all of which were burning issues in the Kentucky campaigns and the subject of later Supreme Court decisions :

(1) Act of April 9, 1866, c. 31, 14 STAT. 27-30. "An act to protect all persons in the United States in their Civil Rights, and furnish the means of their vindication." 39th Cong., 1st Sess. This legislation defined United States citizenship as extending to all persons born in the United States and declared that citizens shall have "the same right" to make and enforce contracts, sue, be parties, give evidence, inherit, purchase, hold and convey real and personal property, and to the full and equal benefit of the laws for security of person and property "as is enjoyed by white citizens." Any person who "under color of any law, statute, ordinance, regulation or custom, shall subject . . . any inhabitant . . to the deprivation of any right secured ... by this act" was made subject to a fine of $\$ 1000$ or one year imprisonment or both.

(2) Act of May 31, 1870, c. 114, 16 STat. 140-46. "An act to enforce the Right of Citizens of the United States to vote in the several States of this Union, and for other Purposes." 41st Cong., 2d Sess. This act declared that citizens of the United States otherwise qualified to vote at state or municipal elections were not to be barred by reason of race, color or previous condition of servitude, any constitution or law of a State notwithstanding; voting prerequisites must not discriminate against anyone because of race, and state officers who refused to accept voters because of race were made subject to prosecution, as was any person or combination intimidating or preventing a citizen from voting; finally, it was declared a crime for two or more persons to go on the public highway or premises of another with intent to violate the act or injure any person in the exercise of his constitutional rights.

(3) Act of April 20,1871, c. 22, 17 Stat. 13-15. "An act to enforce the prozisions of the Fourteenth Amendment to the Constitution of the United States. ..." $42 \mathrm{~d}$ Cong., 1st Sess. This made any person who under color of law, deprived another of a federal constitutional right liable to suit by the injured party in federal court, and provided responsibility in damages for two or more persons who, among other crimes, conspired or went in disguise on the highway to interfere with voting or trials, to deprive a person or class of equal civil rights or to prevent state authorities from protecting those rights.

(4) The Act of March 1, 1875, c. 714, 18 StaT. 335-37. "An act to protect all citizents in thcir civil and legal rights." 43d Cong., 2d Sess. This entitled all persons within the jurisdiction of the United States to full and equal enjoyment of inns, public conveyances on land or water, theaters and other places of public amusement, subject only to the conditions established by law and applicable to all citizens, without reference to race and color. Persons discriminating would be guilty of a misdemeanor and the "person aggrieved" was given the right to a civil suit for $\$ 500$ damages. The act also provided that no person otherwise qualified should be barred because of race from serving as a grand or petit juror in any state or federal court, and penalized any person charged with the duty of selecting jurors who excluded persons because of race. 
if the state authorities, who can act more efficiently than any others, will not protect its citizens in the enjoyment of their inalienable rights; if our courts are to be intimidated, and the laws trampled under foot by a band of cut-throats and murderers, I trust that some power will prove itself sufficiently strong to grapple with such monsters." 90

When questioned about the constitutionality of the recently-enacted Federal "Anti-Klan" Act of 1871, Harlan replied, "I have carefully examined that Kuklux Bill, and while I entertain some doubts as to the constitutionality of one of the provisions in that bill, I see nothing in it to create any serious alarm among the law-abiding citizens of Kentucky."91 In another speech, he discussed his attitude toward states-rights by saying that he belonged "to that school of politicians, which teaches me, that I owe a paramount allegiance to the Government of the Nation. ..." Although he respected "the just authority of the State," he could never forget that the Constitution and all laws made in pursuance thereof "are the supreme laws of the land, anything in the Constitution or the laws of the States to the contrary notwithstanding." He called on the people of Kentucky to submit to the War Amendments on that basis, for any attempt to disturb them would isolate Kentucky from the rest of the country. 92

If quotations from Harlan's former Know-Nothing speeches made good reading to the voters in reply to Harlan's immigration proposals, the Democrats found ten times the ammunition in Harlan's earlier civil rights statements, and Democratic campaigners laughed away Harlan's explanation that he would rather be "right than consistent." Harlan's opponent, Preston H. Leslie, stated that Harlan had assured the people that Republican civil rights policies were "revolutionary, and if carried out would result in the destruction of our free government." "That was a correct view of it. . . ," Leslie said. ${ }^{93}$ Throughout the campaign Democratic orators branded Harlan a "political weathercock" and printed his earlier statements in opposition to the War Amendments, congressional civil rights acts and Negro suffrage. ${ }^{94}$ They also advanced the argument, much as Harlan had put it in 1865, that the Republicans were advocating "social equality" between whites and Negroes. Harlan's reaction to the charge was to deny it. "What do they mean by this cry of

90. Genteral Harlan's Republicanism, supra note 87, at 6.

91. Louisville Daily Commercial, July 29, 1871, Document, supra note 40, at 63 n.69.

92. General Harlan's Republicanism, supra note 87, at 6,7.

93. Cincinnati Daily Gazette, June 3, 1871, Hartz, supra note 12, at 34.

94. Louisville Courier-Journal, July 28, 1871, ibid. Harlan met the charges of inconsistency head on:

"Now fellow citizens, probably some of you will say that I have been inconsistent on the subject of slavery. I grant it .... I am here today before this audience, that once knew my sentiments on that subject, to say that I regret that I ever advocated the sentiments which $I$ expressed before you in 1859, and there is no man on this continent, from the lakes on the North to the Gulf on the South, that rejoices more than I do at the extinction of slavery on this continent ...."

Louisville Daily Commercial, May 26,1871, Document, supra note 40 , at 70 . 
Negro equality? Do you suppose that any law of the State can regulate social intercourse of the citizen? .... We do not declare as the Democratic orators well know, in favor of social equality. No law ever can or will regulate such relations. Social equality can never exist between the two races in Kentucky." Stressing that what he advocated was the full legal equality of Negroes with whites, Harlan illustrated the distinction by saying that, in the public schools, it was obviously "right and proper" to keep "whites and blacks separate."96

\section{Consolidating the New Position}

Harlan had not expected to win the governorship and he did not. He did succeed in piling up 89,000 votes for the "New Republicanism," 63,000 more than the party had received in the last state election. As one Republican observed, "the long, dark, dreary night of Republicanism in Kentucky" was over. ${ }^{07}$ While the Republican Party would not carry Kentucky for the presi-

95. Louisville Daily Commercial, July 29, 1871, Hartz, supra note 12 , at 34-35.

96. Cincinnati Daily Gazette, June 3,1871 , id. at 35 .

97. Coulter, op. cit. supra note 20 , at 437 . Within a month after his gubernatorial campaign and his strong indictment of the Klan, Harlan became involved in a curious affair. In August and September of 1871 a series of Klan outrages broke out in the Frankfort area, including the hanging of several Negroes. Harlan, on his way to discuss Kentucky political affairs with President Grant, wrote his law partner, Benjamin Bristow, that both white and black Republicans were being intimidated and were fearful of resorting to the federal courts. In his view, "The Federal Court ought to have a grand jury in perpetual session and summon every body until they find out who the Kuklux are .... [I]t is the only road to root out the evil." J.M.H. to Benjamin Bristow, Sept. 16, 1871, Bristow Papers, Library of Congress.

The federal district attorney, Harlan's close friend, G. C. Wharton, did obtain indictments against a group of men suspected of being the Klansmen who had committed the crimes. His docket crowded with these cases, Wharton wrote Bristow that he badly needed General Harlan as special counsel in the cases and asked Bristow, who was then in Washington as Solicitor General of the United States, to see if Harlan could not be appointed to assist him. G. C. Wharton to Bristow, Sept. 24, 1871, ibid.

Instead, however, Harlan accepted employment on behalf of several of the men accused of the Klan crimes. Having just told President Grant to use federal power against the Klan, Harlan wrote to Bristow:

"There are some matters connected with this Kuklux business which embarrasses me-I must urge the Gov't to 'go for' the Kuklux-and yet I am being applied to defend, as counsel, some who are charged with being Kuklux. I once thought that I would have nothing to do with cases of this kind-but, upon reflection, I find that I must play lawyer in these as in other cases, [or else] abandon good fees which I am not able to do. While I was urging and endorsing Wharton to get after the Kuklux, here comes Howard Smith after me to defend his son-I could not resist his appeal, and did not feel that I ought to decline-and I am glad that I defended his son for he clearly established an alibi and nobody believes him to have been guilty. ..."

J.MI.H. to Bristow, Sept. 27, 1871, ibid.

This action brought down on Harlan a wave of criticism from colored people and mild disapproval from his Republican friends. "Before God," one Negro woman exclaimed, "I thought the Custom House would not hold enough money to employ General Harlan for 
dency or governorship until 1896, it was a revitalized and united party that Harlan had built, and the Republicans were to play an important role in the political and economic life of the State, a role which the old Radicals had never been able to manage.

In 1872 the Republican State Convention chose Harlan as its favorite-son nominee for Vice-President of the United States, and, once Grant and Wilson had been nominated, Harlan went through Kentucky and the surrounding states speaking for the Republican ticket. ${ }^{98}$ During the presidential campaign Harlan received a telegram from Senator James G. Blaine, asking him to come to Maine to speak for the ticket there. Accepting the invitation, Harlan found himself one of fifteen or twenty speakers from different states who had been assembled by Blaine for a two-week, "whirlwind" campaign. One incident which took place during that campaign provides insight into Harlan's personal attitude toward Negroes at this point. He described it as follows:

"Before the speakers started through the State they all dined with Blaine at his residence in Augusta. I was assigned to a seat between Frederick Douglass [the famous Negro orator and writer] and Benjamin F. Butler [a leading Radical Reconstructionist who had ruled New Orleans as Military Governor]. . . . Of course, I made no objection to the place of the assignment at Blaine's table. In fact, I rather liked it, for Douglass and Butler were both very remarkable, interesting men. Douglass and I spoke together several times during my Maine campaign. In my judgment, he had no superior as a public speaker. He would have made a great Senator."

The following year Harlan was appointed by George $\mathrm{H}$. Williams, Attorney General of the United States, "to assist in prosecutions for violations of the Enforcement Acts of Congress."100 Harlan took the oath of office at once ${ }^{101}$ and participated in civil rights cases arising in the federal district of Kentucky.

those men!" Quoted in Wharton to Bristow, Oct. 1, 1871, ibid. To Bristow, Harlan confided, "My colored friends, some of them, cannot understand how $I$ defend Kuklux. Some of them think, in their ignorance, that I have deserted them. Altogether my position is embarrassing politically, but I cannot help it-for I cannot afford to decline practice in my profession." J.M.H. to Bristow, Sept. 29, 1871, ibid.

Negro sentiment against Harlan did not last long, however. Between 1871 and 1874 he defended a colored Methodist Congregation to whose church the Southern Methodists tried to claim title, and in 1873 Harlan was counsel, along with Colonel Wharton, in a suit under the Federal Enforcement Acts to oust the municipal officials of Lexington from office because of their excluding of Negro voters from the polls. Brief of John M. Harlan for Appellees, Watson v. Bradshaw, Court of Appeals of Kentucky, 1874, Library of the Supreme Court of the United States; A. H. Adams to Benjamin Bristow, March 21, 1873, Bristow Papers, Library of Congress.

98. Political Memorandum, supra note 11 , at 15-16.

99. Id. at 16.

100. Telegram from Williams to J.M.H., Feb. 11, 1873, Harlan Papers, Author's Possession.

101. Source Chronology File, p. 592, Feb. 12, 1873, Dep't of Justice Files, Washington, D.C.

During 1874 the White Man's League carried out a program of organized anti-Negro 
In 1875 Harlan was chosen again by the Republicans as their gubernatorial nominee over Harlan's "earnest protest."102 Again, Harlan waged a vigorous campaign, this time against James B. McCreary for the Democrats. Early in the campaign it became clear that the civil rights issue was still at the forefront in the minds of Kentucky voters, and that the Democrats intended to continue their attack on Harlan's pro-civil rights position. At one point in the campaign, as Harlan was about to enter a court house to speak, a friend warned him that the Democrats had planted "some ugly questions" to be asked him. When Harlan was well along in his talk and had paused for a sip of water, a man rose suddenly in the audience and asked Harlan: "It is rumored among the people here that you sat by the side of a negro at a dinner table in Maine a few years ago. How is that?" Harlan, after asking whether the "contest for the high office of Governor of Kentucky is to depend, it seems, in part upon the question whether I ate dinner at the same table with a man of the Negro race ... ," related the facts of his being seated in that place at Blaine's table. "I ate my dinner in entire comfort," he added, "eating neither more nor less because of Douglass' presence near me. Why fellow-citizens, I not only ate by the side of Douglass at Blaine's house, but during the campaign sat at the same table with him in public hotels and spoke from the same platform with him. And here let me say that there is no man of any party in Kentucky who can make an abler address before a public audience than can Frederick Douglass." Having given the particulars, Harlan concluded his comment by saying: "I not only do not apologize for what I did, but frankly say that I would rather eat dinner any day by the side of Douglass than to eat with the fellow across the way who sought to entrap me by a question which has nothing to do with the contest." The audience applauded thunderously and Harlan continued on with his speech, delighted at the way he had handled his heckler. ${ }^{103}$

The question of eating beside a Negro was more relevant to the campaign than Harlan wanted to admit, however. One of the Democrats' main issues in the campaign was the Federal Civil Rights Act of 1875, ${ }^{104}$ which had pro-

terrorism in Kentucky and in other parts of the South, with little real opposition from local authorities in many areas. This lawlessness alarmed Harlan, and in one letter to Bristow he poured out his view of what these incidents meant:

"The Democratic leaders in the South [intend] ... to force the colored people [of the] South into their ranks, or drive them from the polls-and, thus, give the entire vote [of the] South to the Democratic candidates in 1876. . . . The North must bristle up in the protection of the colored people-otherwise, we will drift into a state of utter helplessne'ss and anarchy.

"I do not think that the remedy lies in mixed schools, as contemplated by the last Civil Rights bill-but in an exhibition of Federal power for the protection of life, liberty and free elections. If the persecution of the colored people will unite the North in 1876, in opposition to the Democratic party, all will be well."

J.M.H. to Bristow, Aug. 28, 1874, Bristow Papers, Library of Congress.

102. Political Memorandum, supra note 11, at 17 .

103. Id. at $17-19$.

104. 18 Stat. 335 (1875); see note 89 supra. 
hibited discrimination against Negroes in inns, theaters and public carriers. Charging that this gave Negroes greater privileges and legal rights than whites enjoyed (again a theme which Harlan had sounded himself in 1865), the Democrats challenged Harlan to state where he stood on the congressional act. Harlan responded, throughout the campaign, by denying that the act meant what the Democrats said it did and by accusing his opponents of trying to arouse racial prejudice. ${ }^{105}$ "The clear and manifest purpose of the Act," Harlan said, "as seen upon its face, was to secure equal, not superior, privileges to the colored race. Whatever rule or usage was applicable to whites in the matter of public conveyances, was intended by that bill, to be made applicable alike to the colored race." 106 Harlan added that, independent of the Civil Rights Act, he believed that "under the law of Kentucky today, any one of the colored men within the sound of my voice has the same right--that any white man possesses to ride in one of your cars from here to the city of Louisville."107 Harlan seemed to be uncomfortable with the act's application to private individuals, though, just as he had been to "one provision" of the Anti-Klan Act of 1871. In discussing the 1875 act, Harlan called the attention of his listeners to a ruling which had just been made by the federal circuit judge for the district in which Kentucky was located. The grand jurors had asked Judge Emmons whether the act of 1875 required them to indict private persons who denied accommodations to Negroes, and Emmons had instructed them that it did not, since Congress had no power under the Thirteenth or Fourteenth Amendments to regulate discrimination by other than state governments. Harlan announced:

"In the conclusion which that distinguished Republican jurist reached, I concur, I do not believe that the Amendments to the Constitution authorize the Federal Government to interfere with the internal regulations of theater managers, hotel keepers or common carriers within the states in reference to the colored man, any more than it does in regard to white people. .. . These are matters of local concern, to be determined and regulated by local authority. ..."108

To Harlan, the Civil Rights Act of 1875 had "ceased to have a practical importance in this State" after the Emmons ruling. The Negro people, he said, had not sought to cause racial trouble "in reference to the matters covered by the last Civil Rights bill," and it was only the attempt by the Democrats "to excite the people" over the act which was creating difficulties. ${ }^{108}$

Following in the mold of the 1871 campaign, Harlan's speeches were defenses of emancipation and the War Amendments, of the Civil Rights Act of 1866 and the use of Negro testimony in state courts, of the full enjoyment of

105. General Harlan's Republicanism, supra note 87, at 7-10.

106. Id. at 9.

107. Ibid.

108. Ibid.

109. Id. at 10 . 
legal rights by Negroes and the distinction between legal and social rights. ${ }^{110}$ Again, Harlan called for an end to race-politics and anti-Negro agitation. Praising the progress of Negroes since the abolition of slavery, Harlan declared that he was confident that "the white and black races can move along in this free land of ours, each cherishing, if you please, the prejudices of race without at all interfering with the just rights of the other."111 Voicing a religious brotherhood theme, Harlan said,

"Here those people are and here they will remain. They have been created as we have been, in the image of the Maker, and every dictate of humanity, to say nothing of self-interest, imperatively demands that political organizations shall cease to keep alive the prejudices and passions which grew out of the abolition of the institution of slavery.

"The Republican Party claims for that race no right which does not belong to them under the Constitution and laws of the land, and a citizen who proposes to deny them such rights is no friend of the law, is an enemy of our free institutions, and no friend of peace."112

As in 1871, the Democrats lashed out at Harlan the chameleon. The Louisville Courier-Journal remarked that "no one can laugh off inconsistency better than he, for his youth, the passions of the time, for which he was not responsible, are always at hand to excuse positions that to his present view are incorrect." 113 Harlan continued in 1875 the economic progress and social reform program which he had framed in the previous election, particularly the theme that "each and every citizen should be made to bear the burdens of the government in proportion to his ability to pay."114 His platform called for the spread of public education, the encouragement of immigration, a state anti-monopoly program, and similar measures. ${ }^{115}$ The Democratic tide and the hold of War issues were too strong for the Kentucky Republicans, though, and Harlan was defeated, although he continued to raise the Republican vote in the state. ${ }^{110}$

\section{Moving Onto the National Scene}

During 1875 and 1876 Harlan spent most of his spare time marshaling support to win the 1876 presidential nomination for his law partner, Benjamin Bristow, then serving in Washington as Secretary of the Treasury. ${ }^{117}$ As head

110. Id. at 7-16. Harlan wrote to fellow Republicans during the campaign that he expected his position to attract "the bulk of the colored voters." Letter from J.M.H. to R. Gudgell, May 19, 1875, Harlan Papers, Lonisville; J.M.H. to D. C. Swann Wintersmith, May 25, 1875, ibid.

111. Id. at 10 .

112. Id. at 10-11.

113. Louisville Courier-Journal, July 7, 1875, Fartz, supra note 12, at 37.

114. Id. at 40 .

115. 2 ConNelity \& Coulter 1001.

116. Ibid.

117. IJarlan Letters, Bristow Papers, Manuscript Division, Library of Congress; Bristow Letters, Bristow File Box \#1, Bristow File Box \#2, Harlan Papers, Author's Passession. 
of the Kentucky delegation to the Republican Convention of 1876, Harlan made a nominating speech for Bristow which, in keeping with the nomination of a Southerner for the Republican ticket, dwelt almost entirely on Bristow's record of support for the War Amendments, the federal civil rights acts, free schools for whites and blacks to be paid for by a general property tax, and suppression of the $\mathrm{Ku} \mathrm{Klux} \mathrm{Klan-on} \mathrm{all} \mathrm{of} \mathrm{which,} \mathrm{the} \mathrm{implication} \mathrm{was} \mathrm{clear,}$ John Marshall Harlan stood alongside his nominee. ${ }^{118}$

When it became apparent to the Kentucky delegation that Bristow could not be nominated and there was a danger that James G. Blaine, whom the delegation did not favor, might sweep the nomination, Harlan threw the Kentucky votes to Rutherford $B$. Hayes and started the drive which won Hayes the nomination. ${ }^{119}$ Harlan stumped the border-states vigorously for Hayes during the 1876 campaign; when Hayes was elected, it was a simple fact of political life that General Harlan-leader of the Kentucky Republican Party, a powerful Republican campaigner from Maine to Tennessee, and the man who had started the Hayes bandwagon in the Convention-had a major claim upon the new Republican Administration. ${ }^{120}$ His position with Hayes was strengthened by his excellent work as one of the five commissioners sent by the President to Louisiana in the spring of $1877,{ }^{121}$ to decide which of two rival state administrations was the lawful regime. While the Commission's finding for the Democratic claimants angered congressional Republicans, it assisted Hayes greatly in his settlement of reconstruction. In July of 1877 Harlan visited Hayes to discuss appointments for several Kentucky Republicans. Hayes brought up the question of Harlan's future and asked him, "Would a first class foreign mission tempt your ambition?", making it clear that this included "the very best Mission we have-the English Mission." Harlan said he thought not, but took three weeks to think over the offer, "because due respect to the President required that I should not appear to treat his offer lightly." When he saw the President again, Harlan expressed his profound gratitude for the President's offer but stated, as he wrote in a diary, "I could not, at my age of life, afford to live four years in Europe. My family was large and fortune limited, and to surrender my profession for any such public service was impossible."122

In March of 1877 Hayes began consideration of a successor to Justice David Davis, who had resigned from the Court to become United States Senator from Illinois. ${ }^{123}$ Hayes determined to appoint a "Southern man" and spent the

118. Speech of Mr. Harlan, Offictal Proceedings of the National Republican Conventions of 1868, 1872, 1876 ANd 1880, at 290-92 (1903).

119. Morrow, Talks With Notable Men, supra note 7, at 9.

120. Diary of John M. Harlan 14-20, Harlan Papers, Authar's Possession. This twenty-seven page diary was begun on Aug. 21, 1877, and abandoned on Aug. 22, 1877. See Farrelly, John $M$. Harlan's One-Day Diary, August 21, 1877, 24 Filson CuUb Hist. Q. 1-11 (1950).

121. Scrapbook, The Louisiana Commission, 78 pp., typewritten newspaper summaries, Harlan Papers, Anthor's Possession.

122. Diary, supra note 120 , at 5-7.

123. The appointment story is related in Frank, The Appointment of Supreme Court 
usual period entertaining suggestions, sifting candidates and assessing political claims. By September Hayes wrote to a close friend, "Confidentially and on the whole, is not Harlan the man? Of the right age, able, of noble character, industrious, fine manners, temper and appearance. Who beats him?'124 Convinced that there was no one who did "beat him," Hayes sent Harlan's name to the Senate on October 16,1877, for confirmation as Associate Justice of the Supreme Court.

But Harlan was not yet a Justice. A set of complicated factors, focusing around the hostility of congressional Republicans to President Hayes's reconstruction policies and anger at the pro-Democratic report of the Louisiana Commission, caused the Senate Judiciary Committee to delay Harlan's confirmation and begin hearings on his suitability for the Court. ${ }^{125}$ Among the charges made to the Committee by anti-Harlan spokesmen was the allegation that he was not a "real Republican." One letter to the Committee warned:

"I think that some little effort ought to be made to save the Supreme Court from passing into the hands of the late enemies of the Gov't \& their allies. I think that a man who spends months personely [sic] electioneering for a place on the Bench ought to be rejected. I think a man who is by his own confession a particepts criminis to the late debauchery \& revolution at New Orleans will be a dishonor to the bench. I think a man who opposed all the late Cons' amendments is a dangerous man to trust on the bench...."126

Another letter warned the Chairman of the Committee, Senator George Edmunds,

"[A]s sure as you and I live, we will both see the hour when he will be the sycophantic friend and suppliant tool of the Democratic party. He was that when he thought it was to his interest to be so. He reill be so again when he believes that his interests require it."127

Harlan's earlier anti-Negro views played a prominent part in the confirmation fight. Typical of the opposition on this score was a letter from Speed S. Fry, Harlan's commanding general at one point during the Civil War and a Republican candidate for Congress in 1866. Fry, who had fallen out with Harlan on a matter of patronage, told the Committee:

"During my canvass [in 1866] I fell into company with General Harlan in Frankfort, his then home, and in a conversation with me on the subject of negro slavery he was very bitter in his denunciation of the Emancipation Proclamation issued by $\mathrm{Mr}$. Lincoln and in the course of our conversation remarked that 'he had no more conscientious scruples in buying and selling a negro than he had in buying and selling a horse, that the right of prop-

Justices: Prestige, Principles and Politics, 1941 Wis. L. Rev. 172, 204-10 and in Document, supra note 40 . Neither of these accounts come particularly close to the actual situation as revealed in the Harlan, Bristow, Hayes, and Gresham Papers. That story must wait for a later article, however.

124. Hayes to William Henry Smith, Sept. 29, 1877, quoted in Mrs. Harlan, Memories at 78 .

125. Document, supra note 40.

126. W. H. Painter to Senator Edmunds, Oct. 4,1877 , id. at 67 n.79.

127. William Brown to Edmunds, Nov. 19, 1877, id. at 71 n. 88 . 
erty in a negro was identical with that of the property in a horse, and that the liberation of slaves by our general government was a direct violation of the Constitution of the United States. [']"128

Fry added that it was "due" to Harlan to note that since then he had uttered "very opposite sentiments" and "now claims to be a thorough Republican on all the issues growing out of the Amendments to the Constitution affecting the rights of the colored people." 129

Harlan had been warned about these arguments against his nomination by a member of the Judiciary Committee who was strongly supporting him, James B. Beck, Democratic Senator from Kentucky. ${ }^{130}$ To defend himself, Harlan wrote to Senator Beck on October 31st, reviewing his political life and his changes of position, and enclosing extracts from his published speeches showing his support for civil rights measures. ${ }^{131}$ Division within the Judiciary Committee and concerted opposition to Harlan from two Senators prolonged the hearings until November 26th, when the Committee announced to the Senate that Harlan's nomination would be reported favorably. In her memoirs, Mrs. Harlan placed the favorable report of her husband's confirmation as having arrived on Thanksgiving Day:

"It was on Thanksgiving Day, which my husband, as usual, spent at home with his famly, and we had attended the Thanksgiving Service at the College Street Presbyterian Church. After lunch-as he was, naturally, somewhat restless because of the way in which his nomination was hanging fire in the Senate-his three boys urged him to join them in an impromptu game of football which took place upon a common in the outskirts of the city. With great glee they afterwards described to me the way in which their father had played 'full-back' on their side, and how everyone had 'stood from under' when he advanced, with great deliberation and dignity, to kick away the ball whenever it threatened their goal.

"When my four boys (for my husband was always a boy along with his three sons) returned, late that afternoon, to our Broadway home-tired and happy, and hungry for their Thanksgiving Dinner-a telegram was waiting for him, informing him that on that very morning 'the Senate had unanimously confirmed his nomination as an Associate Justice of the Supreme Court of the United States'... The unconscious prophesy embodied in my husband's baptismal name, 'John Marshall' was to be fulfilled...."132

\section{Justice Harlan, The Post-War Court, and Civil Rights}

When Harlan joined the Court in 1877, the Justices had already begun to grapple with the issues arising out of extension of citizenship rights to the Negro.

128. Fry to Brown, Nov. 2, 1877, id. at 70. Fry admitted in his letter that he believed Harlan's influence had gone "very far to defeat me in my application for the office of U.S. Marshall for this Dist. of Ky." Ibid.

129. Ibid.

130. Beck to Harlan, Oct. 29, 1877, Appointment File Box, Harlan Papers, Author's Possession.

131. This letter is printed in full in Document, supra note 40, at 60-68.

132. Mrs. Harlan, Memories at 79-80. 
In three cases coming from United States courts located in border or Southern states, the Court had reversed successful prosecutions of white defendants for depriving Negroes of rights enumerated in the federal civil rights acts: one case involving removal to federal court because of the exclusion of Negro testimony in the state court; ${ }^{133}$ a second, conspiracy to break up a Negro meeting by force $;^{134}$ and the third, infringement of the Negro's right to vote in state elections. ${ }^{135}$ The Court had also overturned, as a burden on interstate commerce, a Louisiana reconstruction law which forbade racial discrimination on public carriers. ${ }^{136}$ Without minimizing the larger constitutional issues involved in these cases, or in the famous Slanghterhouse ${ }^{137}$ opinion handed down during this period, one can observe that the Court had adopted a less than maximum conception as to the civil rights protected by the War Amendments and had chosen interpretations of civil rights laws which left Negro rights unprotected in situations where the equities weighed heavily on the side of a more liberal reading of statutory intent.

To what extent the new Justice would have agreed with these decisions at the moment when he joined the Court is difficult to determine. Given Harlan's strong speeches defending federal intervention when states barred Negro testimony from their courts and his specific opposition to Kentucky's ban, ${ }^{138}$ it seems likely that Harlan would have dissented in Blyew, with its brittle reasoning that two Negroes, the sole witnesses to the murder of another Negro, were not "persons affected" by Kentucky's exclusion of Negro testimony within the meaning of the removal provisions of the Civil Rights Act of 1866. And given Harlan's public support for local regulations guaranteeing equal treatment of whites and Negroes on common carriers, ${ }^{139}$ it seems fair to assume that the new Justice would have broken with the majority in $\mathrm{Hall}$ as well. $\mathrm{He}$ might have felt that the anti-segregation law was a burden on interstate commerce, but this was a position Harlan rarely took when he felt great sympathy for the state regulation which had been adopted. ${ }^{140}$

133. Blyew v. United States, S0 U.S. (13 Wall.) 581 (1872).

134. United States v. Cruikshank, 92 U.S. 542 (1876).

135. United States v. Reese, 92 U.S. 214 (1876).

136. Hall v. DeCuir, 95 U.S. 485 (1878). Professor Clark in his study of Harlan's opinions, Clark, The Constitutional Doctrines of Justice Harlan 90-91 (1915), and Professor Beth in his recent article on Harlan as a dissenter, Beth, Justice Harlan and the Uses of Disscnt, 49 AMr. PoL. Scr. REv. 1085, 1090 (1955), spin elaborate arguments to explain why Harlan did not dissent in Hall, given his general civil rights views. The fact is that Harlan did not participate in the Hall decision, as the Reporter's Memorandum at 95 U.S. vi (1878) makes unmistakably clear.

137. 83 U.S. (16 Wall.) 36 (1873). Avery v. United States, 80 U.S. (13 Wall.) 251 (1872), dealing with a federal indictment for lynching a Negro voter, was disposed of on a procedural point, and Railroad Co. v. Brown, 84 U.S. (17 Wall.) 445 (1873) raised no constitutional issue, since the damage suit of a Negro passenger excluded from cars seating white passengers arose under a congressional statute forbiding segregation as part of the charter terms of a railroad passing through the District of Columbia.

138. See text at pp. 660-61, 666 supra.

139. See text at p. 666 sitpra.

140. Cf. the liquor prohibition cases, Bowman v. Chicago \& N.W. Ry., 125 U.S. 465, 
Three years passed before any further cases involving Negroes were decided by the Court. In 1880 the Court handed down two decisions, under federal civil rights legislation, which upheld the right of citizens to be tried by juries selected without discrimination as to race and to remove their cases to the federal courts if this right was denied by the constitution or laws of a state :141 the Court also upheld a federal indictment against a state judge for excluding potential jurors because of race. ${ }^{142}$ Harlan joined Justice Strong and the majority in each case.

A year later, Harlan wrote the opinion of the Court in Neal v. Delazuare, ${ }^{143}$ reversing a conviction where the trial court had improperly denied a Negro defendant's motion to quash a jury panel because of racial discrimination in its selection. Since this first opinion illuminates nicely several techniques Harlan employed in dealing with civil rights questions, the case is worth examining in detail for purposes of the later analysis section. The defendant, a Negro indicted in Delaware for rape, had petitioned to remove his case to the federal courts, alleging that citizens of the African race, otherwise qualified, were systematically excluded from jury service in New Castle County and the State of Delaware. Removal being denied by the court, defendant moved to quash the indictment and jury panel on the same ground. The state attorney general entered what amounted to a demurrer to this motion, and the trial court ruled for the state. When the court gave as its reason that affirmative evidence had to be produced to show that Negroes had been excluded, defendant asked that the jury commissioners and court officers be called as witnesses to prove his allegations, but this motion was also denied.

Harlan began his opinion by considering the removal issue, which turned on whether the Delaware Constitution of 1831 and a Delaware stätute of 1848, both unrepealed and both limiting jury service to white citizens, constituted a discrimination "by the Constitution and laws of a state" under the relevant section of the Federal Statutes. The question, Harlan noted "is confessedly attended by many difficulties of a serious nature, which might have been avoided by more explicit language in the statutes passed for the enforcement of the amendments. Much has been left by the legislative department to mere judicial construction."144 Construction being unavoidable, Harlan proceeded to hold that a case for removal had not been made out. Delaware, in an explicit state-

509 (1888) (dissenting opinion), and O'Neil v. Vermont, 144 U.S. 323, 366 (1892) (dissenting opinion) ; and state taxation of railroads, Galveston, H.\&S.A. Ry. v. Texas, 210 U.S. 217, 228 (1908) (dissenting opinion). In Louisville, N.O.\&T. Ry. v. Mississippi, 133 U.S. 587, 593-94 (1890) (dissenting opinion), Harlan, without endorsing the Hall doctrine, referred to it to show that the Court was inconsistent in its treatment of state laws forbidding segregation on interstate railroads and those requiring it. See text at pp. 690-91 infra.

141. Strauder v. West Virginia, 100 U.S. 303 (1880) ; Virginia v. Rives, 100 U.S. 313 (1880).

142. Ex parte Virginia, 100 U.S. 339 (1880).

143. 103 U.S. 370 (1881).

144. Id. at 389. (Emphasis added.) 
ment made by the Delaware Supreme Court, had regarded the adoption of the Fifteenth Amendment, plus the absence of any discriminatory legislation after that time, as proof that the earlier state provisions had been annulled. Since Congress did not intend to give a right of removal where the discrimination had not arisen out of the Constitution or laws of a state, Harlan concluded that defendant's motion to remove had been properly denied.

Turning to defendant's motion to quash, Harlan reviewed the doctrine of the 1880 cases that forcing a Negro to submit to a trial before a jury from which all Negroes had been excluded because of their race was a denial of equal protection of the laws under the Fourteenth Amendment "not less forbidden by law, than would be the exclusion from juries, in the States where the blacks have the majority, of the whole white race, because of their color."145 Discrimination had to be proved, however, and the fact that no Negro had served on juries in a state was not, in itself, proof of discrimination. In this case, however, considering the attorney general's agreement to accept defendant's allegations for the purposes of a ruling, the state's failure to introduce contrary evidence, and the state court's declaration, on judicial notice, that Negroes in Delaware were generally unfit to serve on juries, the Court held that a prima facie case had been made out. "It was," Harlan wrote, ". . . a violent presumption which the State court indulged, that such uniform exclusion of that race from juries, during a period of many years, was solely because, in the judgment of those officers, fairly exercised, the black race in Delaware were utterly disqualified, by want of intelligence, experience, or moral integrity, to sit on juries."146

Having held this to be reversible error and the point on which the decision turned, Harlan also lectured the state court for its denial of defendant's application to have the court officers called to substantiate his allegations. "[T] circumstances, in our judgment, warranted more indulgence, in the matter of time, than was granted to a prisoner whose life was at stake, and who was too poor to employ counsel of his own selection." But failure to call the officers was not considered reversible error. ${ }^{147}$

In 1882 Harlan joined a unanimous Court in Pace v. Alabama, ${ }^{148}$ holding that it was not a violation of equal protection for a state to punish adultery or fornication between white and Negro more severely than the same crime committed between two whites, so long as the greater penalty applied to both the Negro and white offender in the former case. In January of 1883 the Court dismissed the indictment of a group of white Tennesseans for beating several Negro prisoners held in state custody and killing one of their number, holding that the key provision of the Federal Anti-Klan Act of 1871 was unconstitutional. Eight judges took the position in United States $v$. Harris ${ }^{149}$ that the

145. Id. at 386 .

146. Id. at 397 .

147. Id. at 396 .

148. 106 U.S. 583 (1883).

149. 106 U.S. 629 (1883). 
Civil War Amendments did not provide Congress with authority to punish private individuals who conspired to deprive persons of their civil rights. Harlan dissented, but solely on a jurisdictional ground relating to certification of division by the circuit court. ${ }^{150}$ As to the merits, Harlan expressed no opinion -the only instance in which he abstained from taking a stand in the thirtynine cases involving Negro rights in which he participated.

That Harlan's failure to participate on the constitutional issue in Harris did not represent a continued indecision on his part as to the constitutionality of congressional sanctions against individual discrimination is clear from another decision in 1883, the Civil Rights Cases. ${ }^{161}$

\section{The Civil Rights Cases}

United States v. Stanley (Kansas), United States v. Ryan (California), United States v. Nichols (Missouri) and United States v. Singleton (New York) ${ }^{152}$ were federal prosecutions of individuals, under the Civil Rights Act of 1875 , for denying hotel and theater accommodations to Negroes because of their race. The four cases had been submitted by the Solicitor General of the United States, S. F. Phillips, on November 7, 1882, with no appearances or briefs for the defendants. In late November, possibly after learning from the conference that he was the only member of the Court convinced of the act's constitutionality, Harlan had a meeting with Senator George F. Edmunds, one of the draftsmen of the act of 1875 and floor leader during the Senate debates on the act's passage. ${ }^{153}$ Edmunds prepared a memorandum for Harlan on December 1st, setting out the various civil rights statutes enacted by Congress in the 1870's, listing the pages in the Congressional Globe where the constitutionality of the measures had been discussed, and assuring Harlan that the debates had drawn "fflly into question the scope of the Fourteenth Amendment."164

On March 29, 1883, another case brought under the Civil Rights Act of 1875 was submitted on briefs to the Court, this one a damage suit under section 2 of the act against a railroad for refusing a Negro woman access to the ladies' parlor car. In Robinson and Wife v. Memphis and Charleston R.R. ${ }^{155}$ the United States was not a party to the suit; the plaintiff, defendant and federal court in Tennessee had all assumed the constitutionality of the 1875 law; and the appeal turned on the court's having allowed the jury to consider as a de-

150. Id. at 644 .

151. 109 U.S. 3 (1883).

152. Ibid.

153. Letter from Edmunds to J.M.H., Dec. 1, 1882, in Scrapbook, Justice Harlan's Dissent in the Civil Rights Case, 1883, at 2-3, Harlan Papers, Louisville, on loan to Author (hereinafter cited as Civil Rights Case Scrapbook).

154. Ibid. Commenting on the Civil Rights Act of 1866, Edmunds noted that "Judge Trumbull [then a leading Senator], now an intense conservative, was then most earnest in defending every part of it as flowing from the natural state of liberty to all men resulting from the Thirteenth Amendment."

155. Consolidated with the other cases in 109 U.S. 3 (1883). 
fense the conductor's belief that the Negro woman had been with a white man and was therefore "an improper person."

The decision of the Supreme Court holding the act of 1875 to be unconstitutional was not announced until October 15, 1883. Justice Bradley gave the opinion of the majority, and Harlan, as was his custom in many cases, delivered an extemporaneous dissent without notes or memoranda, a practice which usually meant that his disagreement with the Court came out in the most pungent terms. ${ }^{150}$ Harlan promised that he would reduce his dissent to writing shortly and provide the country with the particulars of his disagreement with the majority. ${ }^{157}$

The Court's ruling was front page news in most newspapers throughout the country and provided material for many lead editorials..$^{158}$ Naturally, press opinion divided, with newspapers like the New York Times and the Washington Post supporting the majority, and editors of the National Republican, New York World, Dayton Journal and other newspapers supporting Harlan's position. ${ }^{150}$ The most interesting development in the public reaction was an immediate and sustained booming of Harlan for president by many Republican leaders, Negro groups and influential editors. ${ }^{160}$ The New York Times reported that the former Republican governor of Georgia, Rufus Bullock, warning that the Court's decision "raises a new agitation just at a time when

156. Charles Henry Buther, A Century at the Bar of the Suprente Court of THE United States 169 (1942). For the controversy raised over "Harlan's Harangue" and "Harlan's Stump Speech" by the Justice's heated delivery in the income tax case, see Farrelly, Justice Harlan's Dissent in the Pollock Case, 24 So. CALIF. L. Rev. 175 (1951).

157. N.Y. Times, Oct. 16, 1883, Civil Rights Case Scrapbook.

158. The Civil Rights Case Scrapbook contains an extensive collection of newspaper clippings, on which the following discussion is based. A New York Times story described the reception of the Court's opinion in Atlanta and the pressure built up in the South over the future of the Civil Rights Act:

"One year ago Haverly's minstrels played an engagement in Atlanta. A well-dressed Negro named Johnson seated himself in the dress circle from which he was escorted by police officers. Thus matters rested until a month ago, when a suit under the criminal clause of the Civil Rights bill was instituted against Mgr. De'gure and Haveriy's minstrels. Next day Prof. Chase of the colored school here, was on his way to Atlanta from Augusta with several colored students. On being told the news of the suit against Degure, Prof. Chase ostentatiously brought the students into the ladies' car, when a great commotion was made and the Professor narrowly escaped violence. These events created a deep feeling here. By a strange coincidence the same troupe was playing here to-night when the end man announced to the audience the decision of the court. The entire house rose and gave three cheers for the result."

159. Civil Rights Case Scrapbook at 5-17.

160. A mass meeting of over 3000 Negroes and whites was held at Lincoln Hall, Washington, D.C., on October 22 to protest the Civil Rights Cases decision. Professor James M. Gregory chaired the meeting, which heard lengthy analyses of the Court ruling delivered by Colonel Robert Ingersoll and Frederick Douglass, both of whom praised Harlan, to the resounding cheers of the audience. Ingersoll said:

"From this decision, John M. Harlan had the breadth of brain, the goodness of lieart, and the loyalty of logic, to dissent. By the fortress of Liberty, one sentinel 
it was thought the question was settled," predicted to the Times reporter that the Negro question "will again enter politics and upon this issue Judge Harlan could sweep the country for the Presidency. It is possible that people whose votes placed Lincoln in office, who made the negro free, will insist upon Harlan entering the race in order, through him, to complete the establishment of the full rights of the colored man as freeman."161 Colonel Robert G. Ingersoll, the famous Republican orator and civil rights champion, praised Harlan's dissent as the best thing that could have happened to the Republican Party; and he later embarked on a campaign to win the presidential nomination for Harlan. Ingersoll commented:

"For a good while people have been saying that the republican party had outlived its usefulness; that there was very little difference now between the parties. ... This decision says to the republican party, 'Your mission is not yet ended. This is not a free country. Our flag does not yet protect the rights of a human being.' This decision is the tap of a drum. The old veterans will fall into line. This decision gives the issue for the next campaign, and it may be that the supreme court had builded wiser than it knew."162

This theme was embroidered by a host of editorials, such as that in The Commercial entitled, "Justice Harlan and The New Issue." Commenting that Harlan's courageous dissent the year before in the Virginia bond repudiation case had attracted almost as much public attention and approval as his civil rights dissent, the Commercial recommended Harlan as an ideal Republican nominee for 1884. "He is a man of big brain, full of magnetism and decision.

remains at his post. For moral courage I have supreme respect, and I admire that intellectual strength that breaks the cords and chains of prejudice and damned custom as though they were but threads woven in a spider's loom. This judge has associated his name with freedom and he will be remembered as long as men are free."

Proceedings Of The Civil Rights Mass Meeting 47 (1883), Harlan Papers, Author's Possession. A similar meeting was held at Cincinnati, and a resolution was adopted tendering the gratitude of the Negro people to Justice Harlan. Civil Rights Case Scrapbook at 6. The Baltimore American, Oct. 22, reported:

"The recent excitement about the decision of the Supreme Court against the constitutionality of the Civil Rights act has had an effect in at least one direction that was decidedly unexpected; and this is nothing more nor less than the starting of a very healthy presidential boom for Mr. Justice Harlan. The talk about Judge Harlan's candidacy seems to have originated among the colored people, as might well have been surmised, but some very good arguments are heard in many quarters favorable to the suggestion. . . . A gentleman who has attended almost every national convention since 1856 to-day called the attention of The American correspondent [in Washington] to the ease with which Harlan's nomination could be brought about in a Republican convention if the Southern Republicans, white and black, should make a stand for him. ... [T] [The colored people are determined to give the Justice some fitting return for the stand he took in their behalf. ..."

Id. at 8 .

161. New York Times, Oct. 18, 1883, id. at 5.

162. National Republican, Oct. 17, 1883, id. at 5-6. 
He has not been a Stalwart nor a Half-Breed; he has been a Republican. He has the confidence of the North and the love of his party in the South." 163 Other newspapers, like the Baltimore American ${ }^{104}$ and Boston Herald, ${ }^{165}$ reported "A Boom for Harlan" and discussed the possibility that, in addition to his winning the Negro vote, the fact that Harlan was a Southerner would win for the Republican ticket large numbers of Southern votes which ordinarily would go Democratic.

Harlan did his best to silence the boom by announcing that he did not wish to be "embarrassed by politics" and had not authorized use of his name in connection with any presidential race. ${ }^{160}$ To friends who were beginning to warm to the idea of manuevering for him in the pre-convention months ahead, Harlan sent letters stating that he considered political aspirations and a judgeship to be "utterly irreconcilable."167

During these weeks, letters poured in on Harlan from his son (John Maynard), ${ }^{108}$ his former law partner (Augustus Willson), ${ }^{169}$ his cousin (John Marshall Butler), ${ }^{170}$ Wager Swayne (son of former Justice Swayne), ${ }^{171}$ and others urging Harlan to make his opinion "powerful," "uncompromising,"

163. The Commercial, Oct. 18,1883 , id. at 7 .

164. Oct. 22,1883 , id. at 8 .

165. Oct. 22, 1883, ibid.

166. The New York Times wrote, editorially:

"No one who knows Justice HARLAN could doubt that he was perfectly sincere in his conclusions regarding the civil rights law, or could suspect him of being desirous or willing to base any political aspirations on his judicial action. He is now reported as announcing that he does not wish to be 'embarrassed by politics.' It would be well for the country if all the Supreme Court Judges had the same disposition."

N.Y. Times, undated clipping, ibid. The N.Y. Herald echoed this praise, saying:

"Justice Harlan has set a good example to one or two of his colleagues .... The pitiable spectacle of a Chief Justice of the Court [Chase] working for the Presidential nomination is one which, let us hope, will never be repeated, and it is to be regretted that a present member, and one of the ablest lawyers on the bench [Field] does not agree with Justice Harlan in thinking that the most commendable ambition a Supreme Court judge can have is not political but judicial."

N.Y. Herald, undated, ibid. Similar positions were taken by the N.Y. Tribune and Washington Post, undated, $i b i d$.

167. Referred to in Wager Swayne to J.M.H., Dec. 4, 1883, id. at 79.

168. John Maynard Harlan to J.M.H., Oct. 21, 1883, id. at 27.

169. Willson, who had been through the campaigns of the 1870 's with Harlan and discussed the Negro issue with him often, advised his friend:

"Your dissent will not be for a section or a race. It will be for the American people and the American plan of government and it will be for humanity. Lay it deep and honest and in mortal earnest, not for show of course but for humanity and human rights and, under God, it will yet be the law of the land and a pattern for all nations."

Augustus Willson to J.M.H., Oct. 25, 1883, id. at 34.

170. John Marshall Butler to J.M.H., Oct. 23, 1883, id. at 39.

171. Wager Swayne to J.M.H., Oct. 24,1883 , id. at 40. 
"clear" and "short."172 Several correspondents sent Harlan outlines of an ideal opinion and reflections on the legal issues involved, for his guidance. Actually, Harlan was having more than a little difficulty in putting his dissent on paper. In her manuscript memoirs, Mrs. Harlan recalled that her husband had spent many sleepless nights worrying over the opinion. "Many times he would get up in the middle of the night, in order to jot down some thought or paragraph which he feared might elude him in the morning." Psychologically, "it was a trying time for him. In point of years, he was much the youngest man on the Bench; and standing alone, as he did in regard to a decision which the whole country was anxiously awaiting, he felt that, on a question of such farreaching importance, he must speak, not only forcibly but wisely."173

After weeks of work, Mrs. Harlan recalled, the Justice "reached a stage when his thoughts refused to flow easily. He seemed to be in a quagmire of logic, precedent and law."174 At this point, Mrs. Harlan's dainty hand gave a slight tug to events. Troubled by her husband's difficulty, she took out of secret storage Justice Harlan's prize acquisition as a collector of Americana, the inkstand that Chief Justice Roger Taney had used to write all his decisions, including, as the Harlans had often remarked to guests in showing the inkstand, the famous Dred Scott opinion. ${ }^{175}$ Polishing the inkstand and filling it with a fresh supply of ink, Mrs. Harlan removed the other inkwells from the desk in Harlan's upstairs study and placed the Taney stand on the blotter, beside the Justice's writing pad. When Harlan returned from Sunday services at the New York Avenue Presbyterian Church, Mrs. Harlan directed him upstairs, with a mysterious reference to something there that he would want to see. Harlan's delight in seeing the Taney inkstand, which he believed had been lost, had the effect at this particular moment in the drafting of his opinion of breaking his writing block at once:

"The memory of the historic part that Taney's inkstand had played in the Dred Scott decision, in temporarily tightening the shackles of slavery upon the negro race in that ante-bellum days, seemed, that morning, to act like magic in clarifying my husband's thoughts in regard to the law ... intended by Sumner to protect the recently emancipated slaves in the enjoyment of equal 'civil rights'. His pen fairly flew on that day and, with the running start he then got, he soon finished his dissent." "170

172. Id. at $18-40$.

173. "An Inspiring Inkstand," Mrs. Harlan, Memories 96-102, at 100.

174. Ibid.

175. Harlan had discovered the inkstand in the late 1870's, in the office of the Marshal of the Supreme Court, and was so intrigued with the inkstand that the Marshal gave it to the Justice as a gift. Id. at 97. Mrs. Harlan had later hidden the inkstand to prevent her husband from giving it to a niece of Justice Taney, to whom Harlan had promised the souvenir in a moment of Southern chivalry.

176. Id. at 100-02. Once the dissent had been completed and while it was being printed, Harlan wrote letters and sent telegrams to many of his friends who were waiting for the opinion, advising them that it would arrive shortly and asking them to make arrangements with local editors to have the dissent published in full when copies arrived. Harlan's main fear was that a garbled and partial version would go out over the press services, a justifiable concern in 1883 and today as well. See references in George H. Shields to J.M.H., 
How directly the recollection of the Dred Scott case pervaded the logic and structure of Harlan's dissent is apparent on examining the opinion. Harlan was faced with the classic simplicity and power of Bradley's position for the majority: that the clear terms of the Fourteenth Amendment forbade only states and not individuals to discriminate on the basis of race; that Congress had not been given plenary power over citizenship rights by the Fourteenth Amendment in the same way that the "whole subjects" of interstate commerce or coinage had been made federal matters ; ${ }^{177}$ and that the Thirteenth Amendment's ban upon slavery and its incidents could not be stretched to cover private acts of social discrimination against a race. As far as the purpose of the War Amendments was concerned, Bradley argued that while the Amendments were concededly passed to assist the Negro, there had to be some point at which Negroes ceased to be "the special favorite of the laws" and took "the rank of mere citizen."178 And, as a vital consideration, Bradley had maintained that to uphold the act of 1875 would be to enlarge the power of Congress to legislate beyond the wise limits of the Tenth Amendment, since the extension of federal regulation to cover private discrimination would mean that Congress could pass a whole municipal code governing life, liberty and property.

Accepting Bradley's declaration that the basic question was one of the intention and scope of the War Amendments, Harlan contended that the Court's opinion rested on "too narrow and artificial"179 a construction of the constitutional Amendments. To measure the scope of the Amendments, Harlan said, the Court should recall the relation which had existed between the National Government and slavery before the Civil War. Summarizing this, Harlan cited the Fugitive Slave Law of 1793, with its penalties for private persons who hindered the recovery of escaped slaves, and Story's opinion in Prigg v. Pennsylvania ${ }^{180}$ upholding the constitutionality of this provision. He described the comparable section of the Fugitive Slave Law of 1850, upheld in Ableman v. Booth. $1 \$ 1$ The review culminated with a discussion of Taney's opinion in Dred Scott v. Sanford, ${ }^{182}$ holding that Negro slaves had no legal rights as citizens of the United States. For Harlan, the pre-Civil War statutes and cases showed that there had never been any question as to the constitutional power of Congress to legislate directly upon individuals to protect slavery. The issue presented, therefore, was whether Congress had any less power and whether the Court would impose a different standard under a set of constitutional amendments clearly intended to wipe out slavery, destroy its incidents and prohibit discrimination by race in the enjoyment of citizenship rights.

Nov. 10, 18s3, Civil Rights Case Scrapbook at 55; Judge E. Hammond to J.M.H., Nov. 11, 1883, ibid.; John Marshall Butler to J.M.H., Nov. 24, 1883, id. at 59; Wager Swayne to J.M.H., Dec. 4, 1883, id. at 79.

177. Civil Rights Cases, 109 U.S. 3, 17-18 (1883).

178. Id. at 25 .

179. Id. at 26 .

180. 41 U.S. (16 Pet.) 539 (1842).

181. 62 U.S. (21 How.) 506 (1859).

182. 60 U.S. (19 How.) 393,399 (1857). 
As Harlan saw it, there were four separate bases on which to uphold all or part of the act of 1875. At the very least, one of the cases, the regulation of discrimination by a railroad against a Negro passenger traveling from Tennessee to Virginia, could be upheld as constitutional under Congress's power over interstate commerce. Bradley's airy dismissal of that issue on the grounds that Congress had not written the act as a regulation of commerce had been unjustified, Harlan felt, because there had never been any requirement that Congress recite in its legislation exactly which constitutional provision authorized its action. Secondly, Harlan felt that in Anglo-American law innkeepers and railroad corporations were traditionally charged with the duty to serve the public without unfair discrimination. Subject to regulation in the public interest, they were agents and instrumentalities of the state so as to make their discrimination against Negroes state action within the meaning of the Fourteenth Amendment. As a third ground, Harlan felt that the Thirteenth Amendment alone justified the prohibition of incidents of slavery, in the tradition of the Black Codes, and that race discrimination against the new freedmen in their rights to equal access to public accommodation facilities were such incidents.

Finally, the Justice dealt with the Fourteenth Amendment as a constitutional foundation for the act. The first section of the Amendment had included a grant of United States citizenship to all persons born or naturalized in this country. That right, as the Dred Scott case had emphasized, did not exist before the adoption of the Fourteenth Amendment. The enforcement clause of the Fourteenth Amendment gave Congress power to carry out not just the state action portion of the Amendment but all its provisions. Accordingly, Harlan reasoned, Congress could enact all legislation appropriate to safeguard the new right of federal citizenship. In considering what was appropriate, Harlan commented,

" $[I] t$ is for Congress, not the judiciary, to say what legislation is appropriate-that is - best adapted to the end to be attained. The judiciary may not, with safety to our institutions, enter the domain of legislative discretion, and dictate the means which Congress shall employ in the exercise of its granted powers. That would be sheer usurpation of the functions of a co-ordinate department, which, if often repeated, and permanently acquiesced in, would work a radical change in our system of government."183

The interpretation he suggested, in the tradition of $M c C$ ulloch $v$. Maryland, ${ }^{184}$ would not raise the specter of Congress passing municipal codes, Harlan noted, because Congress could protect only those rights "fundamental in republican citizenship"185 as shown by the common practices of the states.

Summing up his position on the Fourteenth Amendment, Harlan returned to the Dred Scott case. That decision, he remarked, had been said to have "overruled the action of two generations, virtually inserted a new clause in the

183. 109 U.S. at 51.

184. 17 U.S. (4 Wheat.) 316,421 (1819).

185. 109 U.S. at $47,55-56$. 
Constitution, changed its character, and made a new departure in the workings of the federal government." If the Supreme Court were to adhere to the constitutional interpretations put forth in the Civil Rights Cases, another Dred Scott situation would be created.

" $[N]$ ot only the foundations upon which the national supremacy has always securely rested will be materially disturbed, but we shall enter upon an era of constitutional law, when the rights of freedom and American citizenship cannot receive from the nation that efficient protection which heretofore was unhesitatingly accorded to slavery and the rights of the master."186

The War Amendment, Harlan reminded the majority, had been passed to reverse the rule of Dred Scott, to insure that the Negro race become "a component part of the people for whose welfare and happiness government is ordained."

"At every step, in this direction, the nation has been confronted with class tyranny, which a contemporary English historian says is, of all tyrannies, the most intolerable, 'for it is ubiquitous in its operation, and weighs, perhaps, most heavily on those whose obscurity or distance would withdraw them from the notice of a single despot.' To-day, it is the colored race which is denied, by corporations and individuals wielding public authority, rights fundamental in their freedom and citizenship. At some future time, it may be that some other race will fall under the ban of race discrimination. If the constitutional amendments be enforced, according to the intent with which, as I conceive, they were adopted, there cannot be, in this republic, any class of human beings in practical subjection to another class, with power in the latter to dole out to the former just such privileges as they may choose to grant."187

Harlan's dissent was regarded by his friends, as well as many editors and lawyers, as his finest judicial opinion. From Freemont, Ohio, came two letters to Harlan from the man who had placed him on the Court, Rutherford B. Hayes, praising the dissent for putting before the country the "necessary" and "noble" sentiments Harlan had expressed.188 Former Supreme Court Justice William Strong told Harlan, "At first I was inclined to agree with the Court but since reading your opinion, I am in great doubt. It may be that you are right. The opinion of the Court, as you said, is too narrow-sticks to the letter, while you aim to bring out the Spirit of the Constitution."189 Former Justice Noah Swayne wrote Harlan that he agreed with the dissent fully: "in my judgment, it is one of the great-indeed one of the greatest-opinions of the Court -does you infinite honor-is all that could be desired-and will make a pro-

186. Id.at 57 .

187. Id. at 61-62.

188. Hayes did not commit himself to the position that Harlan was right on the law but praised Harlan's dissent for its moral and political value. Rutherford $B$. Hayes to J.M..H., Nov. 28, 1883; Jan. 19, 1884, Civil Rights Case Scrapbook at 62, 70.

189. Strong's views were related in J.M.H. to Mallie Harlan, undated, $i d$. at 4 , and J. Hubley Ashton to J.M.H., undated, ibid. 
found and lasting impression upon the Country."190 A letter from one Kentucky Republican political leader, which had its counterpart in several letters from Congressmen and judges, stressed the terrible effect that the majority's decision would have on the future of the Negro in the South:

"It is very clear that the Negro cannot in the old Slave States protect himself-it is equally clear that they will not be protected by State legislation. What is to become of the poor devils it is difficult to foresee. I greatly fear, the Court's action will invite assaults upon the colored people from the worst class of whites in the country. As long as it was understood that the Federal Government felt bound to protect the Negro, there was a healthy fear of the Federal Government by these poor whites-the Negro, except in certain localities in the far South was getting along passably well-now the patriotic vagabond of the South will feel called upon to vindicate the Supreme Court by 'jumping on' the poor darkey!'101

Harlan's opinion prompted more than private correspondence, though. When his opinion was filed, on November 19th, a widespread discussion of the Civil Rights Cases began again in the press. Many influential newspapers considered Harlan's full text to be no more persuasive than the oral dissent he had registered in October. Although the New York Times called Harlan's opinion "a learned, candid, and able paper," it then went on to say : "The tendency during the war period was toward the construction he favors. Since then a reaction has set in, which, so far, is beneficial." The majority opinion "has satisfied public judgment, and Justice HarLan's will hardly unsettle it."102 The Philadelphia Times felt that Harlan had "been swayed largely by . . . sentimental considerations" and, while his opinion was an able job, the Bradley opinion would continue to carry weight among lawyers in a ratio similar to that of the majority to the minority Justices in the case itself. ${ }^{193}$ The Chicago Tribune challenged Harlan on his own ground of judicial self-restraint:

"If the Supreme Court strained the Constitution before the War to give its sanction to Congressional legislation in behalf of the slave-owner, that is not a good reason why it should now strain the Constitution in order to support Congressional legislation which looks to the protection of the freedman beyond the scope of the amendments .... The Supreme Court has merely denied a special interference of Congress to protect the Negro's exercise of social rights which cannot be invoked for the white man's protection."194

The Boston Transcript challenged Harlan's tenet as to the construction of constitutional amendments, writing:

"Judge Harlan alludes to the intent of passing the Civil-rights Act as being accordant with ... the anti-slavery additions to the Constitution. But the intent of a law should not save it, when the law, per se, violates the

190. Noah Swayne to J.M.H., Nov. 20, 1883, ibid.

191. John W. Finnell to J.M.H., Oct. 25,1883 , id. at 37.

192. N.Y. Times, Nov. 19,1883 , $i d$. at 41 .

193. Philadelphia Times, Nov. 19, 1883, ibid.

194. Chicago Tribune, undated, ibid. 
- fundamental idea upon which the Union and Constitution were erected, viz., the perfect autonomy of the States within their prescribed jurisdiction." 105

The New York Daily Tribune, after expressing its view that most Republicans and most Americans were on the side of the majority, attacked Harlan's reading of congressional authority under the Amendments and his analysis of the "State-action" character of inns and railroads. Said the Tribune:

"This is surely straining the Constitution until it cracks. The purpose of a written Constitution is to fix the law. We must adhere to the law as written, or lose ourselves on a sea of doubt and confusion. The meaning of these amendments is plain. One [amendment] abolishes slavery, abolishing what is commonly known as slavery-not giving power to punish acts which may, by a forced construction, be regarded as badges of slavery. The other prohibits any 'State' from infringing upon the rights of citizens. If their clear meaning could be distorted to Justice Harlan's view, it would only be to gain a temporary advantage in a matter of little practical moment by the sacrifice of great principles."196

Many newspapers which commented on Harlan's dissent supported Harlan, though, and estimated that he had the majority of the American public on his side. "Golden Words," the Evening Critic entitled an approving discussion of Harlan's constitutional position ; ${ }^{197}$ Harlan's lone dissent, wrote the St. Louis Globe-Democrat, was the opinion which "construes... [the Fourteenth Amendment] as those who caused it to be adopted meant to have it construed."108 When Harlan said the majority ruling was too narrow, the Pittsburgh Commercial Gazette declared, he "struck a popular chord that will reecho from Maine to California" ;109 Harlan's position, affirmed the Chicago Inter Ocean, will win out over the "diluted Taneyism" of the whole Court; ;00 $^{20}$ according to the Daily Journal, Harlan had the law, prophets, justice and common sense all on his side: "The cold, glittering, icicular stuff that is needed to analyze and bolster up Justice Bradley's opinion for the court is in unhappy and shriveling contrast to the warm, statesmanlike and humanitarian spirit" of the Harlan dissent. ${ }^{201}$ Similar support came from Tacoma, Washington, ${ }^{202}$ and Colorado Springs, Colorado, ${ }^{203}$ from Schenectady, New York ${ }^{204}$ to Dallas,

195. Quoted in The Commercial Gazette, Nov. 22, 1883, id. at 43.

196. N.Y. Daily Tribune, Nov. 22, 1883, id. at 44.

197. Evening Critic, Nov. 19,1883 , id. at 41 .

198. St. Louis Globe Democrat, undated, ibid.

199. Commercial Gazette, Nov. 19, 1883, id. at 42.

200. Inter Ocean, Nov. 20, 1883, id. at 46.

201. Daily Journal, Nov. 20,1883 , id. at 41 .

202. Daily Ledger, undated, id. at 51. It said:

"The appointment of [Harlan] ... surprised the country; it was regarded as the weakest ever made to that august tribunal. Hayes, however, builded better than he knew; General Harlan has proved an able judge, in whose perfect integrity the Bar and the country now have implicit confidence."

203. Daily Gazette, Nov. 24, 1883, id. at 48 .

204. Daily Union, undated, id. at 46-47. 
Texas, ${ }^{205}$ to San Francisco. ${ }^{206}$ Several newspapers highlighted the fact that it was the only Southerner on the Court who had upheld the civil rights of the Negro, that Kentucky was citing equality to New Jersey and Massachusetts. As one newspaper put it:

"It will be remembered that Judge Harlan was not rocked in the cradle prepared by the genius of universal emancipation, nor has he lived all his life upon the mountain peak of high Olympus . . . but from boyhood to ripe and useful manhood, having been born in the midst of slavery, he was surrounded in his native State by all the influences of the demon of caste. Notwithstanding, he rises above all these, clothed in the judicial garments of the Supreme Court. Solitary and alone, he offers a classic ... rebuke to the Court for its inconsistency and unjust decision." ${ }^{207}$

Support of Harlan for the Republican presidential nomination again appeared in the editorial columns and the ticket of Harlan and Robert $T$. Lincoln was put forward as an ideal offering. ${ }^{208}$ At the same time, however, items began appearing in the press disputing the honesty of Harlan's civil rights views. A Frankfort, Kentucky, correspondent gave several newspapers an account of Harlan's opposition to federal civil rights acts in $1866 . .^{209}$ In addition, a story was widely published that Harlan had resigned from the Union Army in 1863 because of his opposition to Lincoln's Emancipation Proclamation ; ${ }^{210}$ he reputedly was fulfilling a promise made when he was raising recruits for his regiment to take his troops off the field if the war became one of emancipation instead of union. ${ }^{211}$ The National Republican, seeing these stories as attempts "to belittle and diminish the force of [Harlan's] opinion by making it appear that it came from one who had preferred the cause of slavery to the cause of the union," went to see Harlan and asked him about the report. Harlan referred the reporter to his official letter of resignation from the Army, which, Harlan stated, had contained his only motive for resigning. ${ }^{212}$ The letter, pub-

205. Norton's Union Intelligencer, Feb. 4, 1884, id. at 49.

206. Daily Examiner, undated, id. at 48 . Other newspaper support for Harlan is collected, $i d$. at $41-54$.

207. Kentucky Republican, Nov. 24, 1883, id. at 45.

208. The summer months, with newspaper attention on the forthcoming Republican Party Convention, brought renewed interest in Harlan. "Why would not Justice Harlan make a splendid President?" asked the Chicago Evening Journal, May 26, 1884, id. at 52; see also Evansville Journal (Indiana), April 26, 1884, ibid.; Washington Chronicle, April 27, 1884, ibid. Congressman William W. Brown of Pennsylvania told the Pittsburgh Commercial Gazette, Jan. 7, 1884, that, after Blaine, he favored Harlan and Lincoln, id. at 48. See also John Marshall Butler to J.M.H., Oct. 23, 1883, id. at 39.

209. Washington Post, undated, probably October, id. at 8. The Post commented: "[T]here is nothing in the constitution as amended, or in the revised and codified statutes, which forbids a man to change his mind."

210. National Republican, Feb. 5, 1884, id. at 54; Indianapolis Journal, Feb. 9, 1884, id. at 91 .

211. Frankfort Tri-Weekly Yeoman, July 21, 1866, Hartz, supra note 12, at 25; Louisville Daily Journal, July 18,1866 , ibid.

212. National Republican, Feb. 5, 1884, Civil Rights Case Scrapbook at 54; portions of the letter are reprinted in text at note 41 supra. 
lished in full by the National Republican in February of 1884 , served to quiet any serious questioning of Harlan's Civil War allegiance to the Union, and closed the immediate phase of public excitement over the Civil Rights Cases.

\section{Harlan's Subsequent Civil Rights Opinions}

Since the Civil Rights Cases provide a comprehensive view of Harlan's constitutional position on racial discrimination problems, the remainder of his civil rights opinions can best be grouped by subject-matter and discussed briefly, as background for some final conclusions about his civil rights philosophy. For convenience, the cases are summarized under the headings of jury issues, voting rights, involuntary servitude cases, school segregation and segregation in transportation.

\section{Jury Issues}

Following his forceful presentation in the Neal case, Harlan was chosen as majority spokesman in the next five jury cases which came before the Court. In Bush v. Kentucky ${ }^{213}$ Harlan had the personal pleasure of vindicating his political position in the 1870's, by holding that two laws disqualifying Negroes as jurors, passed during the seventies by the Democratically-controlled Kentucky legislature, were a denial of a Negro defendant's civil rights. This required a reversal of conviction, Harlan stated, even though the Kentucky Court of Appeals had ruled, in another case decided after this defendant's indictment but before his trial, that the jury laws were unconstitutional. In 1891 and 1895 Harlan enunciated the rule that discrimination in state jury selections could not be raised by a writ of habeas corpus to the federal court since jury discrimination was a question of fact to be determined by the trial judge, appealed in the state tribunals, and brought before the United States Supreme Court only on a writ of error. ${ }^{214}$ In two cases coming from Mississippi in 1896, Harlan reaffirmed first that removal under the relevant section was limited to situations where discrimination arose from the laws of a state, ${ }^{215}$ and second, that a motion to quash on the ground of discrimination in practice had to be evidenced by more than the defendant's sworn allegations. ${ }^{216}$

This close and workmanlike approach in jury cases was followed by Harlan in eight other jury decisions. He supported reversal of convictions, for example, when state courts refused to entertain proof of jury discrimination ${ }^{217}$ or gave frivolous grounds for dismissing the claim of discrimination. ${ }^{218}$ On the other hand, Harlan voted to uphold convictions where evidence of discrimination had

213. 107 U.S. 110 (1883).

214. In re Wood, 140 U.S. 278 (1891); Andrews v. Swartz, 156 U.S. 272 (1895).

215. Gibson v. Mississippi, 162 U.S. 565 (1896).

216. Smith v. Mississippi, 162 U.S. 592 (1896). Harlan did not participate in Tarrance v. Florida, 188 U.S. 519 (1903).

- 217. Carter v. Texas, 177 U.S. 442 (1900).

218. Rogers v. Alabama, 192 U.S. 226 (1904). 
not been presented ${ }^{219}$ or where the trial court had determined that the proof offered did not make out a case of discriminatory practices. ${ }^{220} \mathrm{He}$ also refused to hold that "poll tax" provisions or "read and write the Constitution" requirements for jury duty which did not discriminate on their face against Negroes, could be read as discriminatory apart from proof of discrimination in their application. ${ }^{221}$ In marked contrast with his relation to the Court in other areas involving Negro rights, Harlan came out with the majority in each of the thirteen jury cases he decided.

\section{The Right to Vote}

The Negro's right to vote presented seven cases to the Supreme Court during Harlan's tenure. In Ex parte Yarborough ${ }^{222}$ Harlan joined in holding that Congress's power to protect federal elections supported a conspiracy conviction, under two federal civil rights sections, of eight white men in Georgia who had severely beaten a Negro for casting his vote in a congressional election. Harlan also agreed with the majority in three rulings that the questions were moot when suits challenging the exclusion of Negroes from voting in an 1895 South Carolina constitutional convention ${ }^{223}$ and a 1902 Virginia congressional election ${ }^{224}$ had reached the Supreme Court after the elections at issue had already taken place.

Harlan broke with the majority in James $v$. Bowman, ${ }^{225}$ which involved the conviction of two men for intimidating a Negro voter during a Kentucky congressional election. The Court held that the application in that case of a federal statute forbidding anyone to bribe or intimidate a person in interference with his suffrage rights under the Fifteenth Amendment was unconstitutional. The Fifteenth Amendment forbade only state interferences with voting, and the statute's failure to limit its terms to voting rights in federal elections distinguished the case from Yarborough and deprived it of constitutional support.

Another voting case provides an interesting contrast between Harlan and the man who also would come to be known as "the Great Dissenter." In Giles v. Harris"226 "a colored man, on behalf of himself and on behalf of more than five thousand negroes," brought a bill in equity in the federal circuit court asking that Montgomery, Alabama officials be required to place on the permanent registry of voters the names of petitioner and all other qualified Negro applicants who had been previously refused enrollment at a congressional election.

219. Franklin v. South Carolina, 218 U.S. 161 (1910) ; Martin v. Texas, 200 U.S. 316 (1906) ; Brownfield v. South Carolina, 189 U.S. 426 (1903) ; Murray v. Louisiana, 163 U.S. 101. (1896).

220. Thomas v. Texas, 212 U.S. 278 (1909).

221. Williams v. Mississippi, 170 U.S. 213 (1898).

222. 110 U.S. 651 (1884).

223. Mills v. Green, 159 U.S. 651 (1895).

224. Jones v. Montague, 194 U.S. 147 (1904); Selden v. Montague, 194 U.S. 153 (1904).

225. 190 U.S. 127 (1903).

226. 189 U.S. 475 (1903). 
In addition, the petition asked for a declaration that certain provisions of the Alabama Constitution governing voting were discriminatory and unconstitutional.227 After finding that the circuit court had jurisdiction, Oliver Wendell Holmes declared, for the majority, that it was impossible to grant the equitable relief asked for. First, if the Court accepted petitioner's allegations that the Alabama registration provisions were an unconstitutional scheme, the Court could not then reassume their validity for the purposes of placing additional voters on the fraudulent lists ; to do so would make the Supreme Court a party to the unconstitutional system. Secondly, Holmes declared, the granting of equitable relief depended on the ability of equity to enforce its decrees, and since the state was not a party to the bill and the Court could not supervise the voting to prevent a white conspiracy from disenfranchising Negroes, equity should leave the correction of this issue to the political arm of government. Harlan's dissent was primarily an argument that the circuit court did not have jurisdiction because the petition failed to show the required jurisdictional amount. But, he added, if there had been jurisdiction, he believed that the facts alleged entitled petitioner "to relief in respect of his right to be registered as a voter," since the federal courts were competent "to give relief in such cases as this...."228

\section{Involuntary Servitude}

Harlan found himself dissenting in four out of five involuntary servitude cases presented to the Supreme Court between 1905 and 1911. Clyatt v. United States ${ }^{229}$ involved two Georgia white men who had compelled the return of two Negro debtors from Florida to Georgia to work off a debt. The white men had obtained a warrant from a Georgia magistrate by filing trumped-up charges of larceny against the Negroes, and had shown this to a Florida sheriff, who had turned the Negroes over to the white men. The indictment, under the Peonage Abolition Act of $1867,{ }^{230}$ charged the white men with violating the act's provisions against "returning," "arresting" or "holding" another "to

227. Id. at 482 .

228. Id. at 503-04. In 1888 Harlan wrote President Benjamin Harrison that the Negro vote for the Republicans in Kentucky comprised about one-fourth of the party's total and that Negroes had no trouble in voting there. J.M.H. to Benjamin Harrison, Dec. 25, 1888, Harrison Papers, Library of Congress. By 1900, however, the campaign of the Southern Democrats to disenfranchise the Negro began to take hold in Kentucky and Harian became concerned about this prospect. Writing to William Howard Taft, Harlan noted:

"What is to be feared is the inauguration of a red shirt campaign in the counties in $\mathrm{Ky}$ where the negroes are numerous. We are approaching a real crisis in the South. In the former Confederate states, or in most of them, there is a fixed purpose to destroy the right of the negro to vote despite the provisions of the Constitution. It is to be seen whether that plan will be upheld by the courts, or sustained by popular sentiment."

J.M.H. to Taft, Aug. 6, 1900, Taft Papers, Library of Congress.

229. 197 U.S. 207 (1905).

230. Rev. Stat. § 1990 (1875), 42 U.S.C. § 1994 (1952). 
peonage." The majority upheld the constitutionality of the act under the Thirteenth Amendment but reversed the conviction because they felt an indictment that charged only "returning to peonage" had to demonstrate that the Negroes were originally in a state of peonage. Here the Court would have to rewrite the indictment into one for "holding" or "arresting" to bring it within the facts of the case, since the record disclosed only a prior debt to the white men. Harlan, arguing that peonage was "based upon the indebtedness of the peon to the master," felt that the prior debt was enough to make out a case of "returning." Furthermore, the defendant had made no objection to the submission of the case to the jury on this indictment, "and it is going very far to hold in a case like this, disclosing barbarities of the worst kind against these negroes, that the trial court erred in sending the case to the jury."231

The following year Harlan dissented again, in Hodges $v$. United States, ${ }^{232}$ involving a conviction of twelve white men who had forcibly prevented a group of Negroes, because they were Negroes, from working in an Arkansas lumber mill. The Court held that the application in this case of the federal provision forbidding anyone to deprive another of his civil rights could not be supported either by the Thirteenth Amendment, which covered only situations involving slavery or holding in servitude, or the Fourteenth Amendment, which reached only state action. Harlan argued that a private conspiracy to prevent Negroes from exercising their right to dispose of their labor was a reinstitution of "the badges and incidents of slavery" and a denial of rights guaranteed the Negro by the Thirteenth Amendment. ${ }^{233}$

Harlan disagreed with Holmes and the majority again in the first Bailey $v$. Alabama case, ${ }^{234}$ a situation which paralleled their split in Giles. At issue was an Alabama statute which penalized the obtaining of money under a written contract of work, with intent to defraud the employer. A Negro indicted under the statute had filed a state habeas corpus action before trial, claiming that the statute imposed involuntary servitude since it made the refusal to work prima facie evidence of a fraudulent intent and since local practice disallowed testimony as to actual intent. The state courts had denied the writ. Dismissing the Negro's appeal, Holmes held the habeas corpus action premature; it was not certain that the state would employ either the statutory presumption or the local practice at the trial and, if actual intent were proved, the case would be a valid punishment for fraud. Furthermore, the state court itself could have denied the writ as being premature under Alabama practice. Harlan's dissent observed that the Alabama Supreme Court had devoted its entire opinion to arguments upholding the constitutionality of the state statute, with its presumption, and had said nothing about the case being prematurely presented on the writ of habeas corpus. Since the state court governed state practice, had

231. 197 U.S. at 223.

232. 203 U.S. 1 (1906).

233. Id. at 20-28. Harlan did not register a dissent in United States v. Powell, 212 U.S. 564 (1909), a per curiam opinion disposing of a case according to the Hodges rule. 234. 211 U.S. 452 (1908). 
accepted the defendant's appeal, and had explicitly declared that the law was not in violation of the United States Constitution, Harlan was unable to see why this was not a final judgment of a state court which the Supreme Court should review. ${ }^{235}$ Three years later, when conviction of the same defendant produced the second Bailey case, ${ }^{236}$ Harlan was with the majority which struck down the Alabama statute as a violation of the Thirteenth Amendment, with Holmes dissenting.

\section{School Segregation}

The issue of segregation in education came before Harlan in two cases. Cumming $v$. Board of Education, ${ }^{237}$ in 1899, was an injunction suit by Negro taxpayers in Georgia directed against a county board of education which had closed a high school for sixty Negro students to provide necessary facilities for 300 colored grammar school students. Harlan wrote the opinion for a unanimous court, holding that there had been no proof of an intention by the school board to discriminate against Negro children because of their race, but only . an apportionment of available funds according to greatest need. Furthermore, Harlan noted that an injunction to force the Board to withhold tax money from the white high school until a Negro high school was provided was not a proper way to question whether the Board's refusal had been based on racial discrimination. Harlan was careful to point out that the question of the constitutional validity of separate schools had not been decided by the Court:

"It was said at the argument that the vice in the common school system of Georgia was the requirement that the white and colored children of the state be educated in separate schools. But we need not consider that question in this case. No such issue was made in the pleadings. Indeed, the plaintiffs distinctly state that they have no objection to the tax in question so far as levied for the support of primary, intermediate, and grammar schools, in the management of which the rule as to the separation of races is enforced. We must dispose of the case as it is presented by the record." "238

\section{Id. at 455-59.}

236. 219 U.S. 219 (1911).

237. 175 U.S. 528 (1899).

238. Id. at 543-44. Harlan also noted:

"We may add that while all admit that the benefits and burdens of public taxation must be shared by citizens without discrimination against any class on account of their race, the education of the people in schools maintained by state taxation is a matter belonging to the respective states, and any interference on the part of Federal authority with the management of such schools cannot be justified except in the case of a clear and unmistakable disregard of rights secured by the supreme law of the land."

\section{Id. at 545 .}

The fact that Harlan had felt, in the $1870^{\circ}$ s, that integrated schools were not a necessary part of Negro civil rights probably explains his willingness to refrain from discussing the separate-but-equal issue. That it was not Harlan's practice to allow procedural issues to preclude a consideration of what he felt were constitutional rights of a litigant is indicated by case's such as O'Neil v. Vermont, 144 U.S. 323 (1892). 
The second school case, Berea College v. Kentucky, ${ }^{239}$ was particularly meaningful for Harlan because of his personal acquaintance with the famous private college founded by Kentucky religious abolitionists in the 1850's to educate the nonslaveholding mountaineers. Berea College had been convicted and fined $\$ 1000$ under a 1904 Kentucky law forbidding any person or corporation to operate a school "where persons of the white and Negro races are both received as pupils for instruction ...." The majority upheld the conviction on the ground that Kentucky law reserved to the legislature the right to amend the charters of corporations within the state and, separating the prohibition as to corporations from that as to private persons and associations, the Court upheld the application of the 1904 statute to Berea College. Harlan's dissent attacked the notion that separability could be justified when a statute was so clearly aimed by the legislature at all private institutions teaching white and Negro pupils, whether the institutions were run by individuals, associations or corporations. Even the state court, Harlan pointed out, had decided the general constitutional issue and had suggested only incidentally, at the end of its opinion, that defendant was a corporation which could be controlled as the state saw fit. Concerning the constitutional issue, Harlan maintained that the law was an invasion of the liberty and property rights of private individuals guaranteed by the Fourteenth Amendment. If the state could constitutionally forbid the voluntary mingling of races in private institutions, Harlan asked, why could it not forbid white and colored children to sit together in church or forbid children of the Anglo-Saxon and Latin races or the Christian and Jewish faiths to associate in private schools, or forbid white and colored citizens to attend the same market places or meet together to discuss public questions ?240

"Have we become so innoculated with prejudice of race that an American government, professedly based on the principles of freedom, and charged with the protection of all citizens alike, can make distinctions between such citizens in the matter of their voluntary meeting for innocent purposes simply because of their respective races? . . Many other illustrations might be given to show the mischievous, not to say cruel, character of the statute in question, and how inconsistent such legislation is with the great principle of the equality of citizens before the law."241

\section{Segregation in Transportation}

Four cases dealing with separation of the races in transportation were presented to the Supreme Court during Harlan's judicial career, and he dissented in each. In Louisville, New Orleans and Texas Ry. v. Mississippi, ${ }^{242}$ the Court, limiting its discussion to the commerce clause issue, upheld the prosecution of a railroad maintaining an interstate route from Tennessee to Louisiana for failing to provide separate accommodations for whites and Negroes as

239. 211 U.S. 45 (1908).

240. Id. at 58-71.

241. Id. at 69 .

242. 133 U.S. 587 (1890). 
required by a Mississippi law. Justice Brewer considered "conclusive" the Mississippi Supreme Court's construction that the statute applied solely to the intrastate portion of the railway trip. Brewer distinguished Hall v. DeCuir ${ }^{243}$ on the ground that in that case the effect of the Louisiana law forbidding discrimination on interstate carriers traveling within the state was to compel white passengers to share their steamboat cabins with colored passengers during the portion of the trip in Louisiana, a burdensome requirement which constituted interstate regulation and could be applied only by Congress. Harlan attacked this distinction, pointing out that the Mississippi act requiring an interstate carrier to send its trains through Mississippi with separate accommodations was every bit as burdensome on interstate operations as was the Louisiana law. ${ }^{244}$ Harlan's dissent added that the clear interference of the Mississippi statute with interstate commerce made it unnecessary to discuss "other grounds upon which, in my judgment, the statute in question might properly be held to be repugnant to the Constitution of the United States. . .".245

The "other grounds" were spelled out at length by Harlan six years later in the famous Plessy $v$. Ferguson ${ }^{\mathbf{2 4 6}}$ case. Plessy was a prosecution of a Negro passenger for refusing to obey a Louisiana statute requiring separation of whites and Negroes on railway cars. The majority opinion, written by Justice Brown, maintained that the basic question was whether the Louisiana law was a reasonable regulation under the Fourteenth Amendment. Deciding that it was, Brown declared that the "underlying fallacy" of the Negro's argument was the

"assumption that the enforced separation of the two races stamps the colored race with a badge of inferiority. If this be so, it is not by reason of anything found in the act, but solely because the colored race chooses to put that construction on it. ... If the civil and political rights of both races be equal, one cannot be inferior to the other civilly or politically. If one race be inferior to the other socially, the Constitution of the United States cannot put them upon the same plane." 247

Harlan's dissent in Plessy ${ }^{248}$ was, in this writer's judgment, his most powerful civil rights opinion. Admittedly, Harlan said, the separation law applied equally on its face to whites and Negroes, but its purpose was obviously to exclude Negroes from the cars where whites sat, and not vice versa. ${ }^{249}$ If this purpose could be effected by state law, without violating the Constitution, the state could compel Negroes to use one side of the street and whites the other, or punish whites and Negroes who rode together in street cars or open vehicles, or assign whites to one side of a courtroom and Negroes to the other, or require separate galleries in public halls for whites and Negroes. The state could

243. 95 U.S. 485 (1878).

244. 133 U.S. at 592-95.

245. Id. at 594-95.

246. 163 U.S. 537 (1896).

247. Id. at $551-52$.

248. Id. at $552-64$.

249. Id. at 557. To a Court which had just maintained the opposite, Harlan remarked: "No one would be so wanting in candor as to assert the contrary." Ibid. 
also separate, on railroad cars, Protestants from Catholics, or native born from naturalized citizens. The Court's answer to these hypothetical queries, Harlan noted, was that regulations of this kind would be unreasonable. But this was not a proper answer. A rule that the races may be constitutionally separated as long as the Supreme Court of the United States considers it reasonable would put the judiciary in the business of passing on "the policy or expediency" of legislation, a role beyond the Court's proper function. ${ }^{250}$ There was already, Harlan warned (fresh from his dissents on this point in the income tax and antitrust cases of 1895), ${ }^{251}$ too much of a "dangerous tendency in these latter days to enlarge the functions of the courts, by means of judicial interference with the will of the people as expressed by the legislature."252 In this case, the Court was creating an exception to the coverage of the Fourteenth Amendment and setting itself up as a super-legislature.

But if the issue had to turn upon the reasonableness or unreasonableness of the compulsory separation laws, Harlan felt that the correct analysis of that problem was far different from that enunciated by the majority. Warning that the judgment in Plessy would, "in time, prove to be quite as pernicious as the decision made by this tribunal in the Dred Scott case,"253 Harlan said that the majority opinion accepted the notion that "we have yet [even after the War Amendments] in some of the states, a dominant race-a superior class of citizens, which assumes to regulate the enjoyment of civil rights, common to all citizens, upon the basis of race." $254 \mathrm{He}$ also noted:

"The white race deems itself to be the dominant race in this country. And so it is, in prestige, in achievements, in education, in wealth and in power. So, I doubt not, it will continue to be for all time, if it remains true to its great heritage and holds fast to the principles of constitutional liberty. But in view of the Constitution, in the eye of the law, there is in this country no superior, dominant, ruling class of citizens. There is no caste here. Our Constitution is color-blind, and neither knows nor tolerates classes among citizens. In respect of civil rights, all citizens are equal before the law.... The law regards man as man, and takes no account of his surroundings or of his color when his civil rights as guaranteed by the supreme law of the land are involved. It is, therefore, to be regretted that this high tribunal, the final expositor of the fundamental law of the land, has reached the conclusion that it is competent for a state to regulate the enjoyment by citizens of their civil rights solely upon the basis of race."2\$5

The "thin disguise of 'equal' accommodations for passengers in railroad coaches will not mislead anyone," Harlan continued, since the legislation was openly "conceived in hostility to, and enacted for the purpose of humiliating,

250. Id. at 558 .

251. Pollock v. Farmers' Loan and Trust Company, 157 U.S. 429, 653-54 (1895), modified on rehearing, 158 U.S. 601, 638-87 (1895) ; United States v. E. C. Knight Co., 156 U.S. 1, 18-46 (1895).

252. 163 U.S. at 558.

253. Id. at 559 .

254. Id. at 560 .

255. Id. at 559 . 
citizens of the United States of a particular race. . .."256 He felt that the majority's ruling would only "encourage the belief that it is possible, by means of state enactments, to defeat the purposes which the people of the United States had in view when they adopted the recent amendments of the Constitution"; this could only lead to disastrous consequences.

"The destinies of the two races, in this country, are indissolubly linked together, and the interests of both require that the common government of all shall not permit the seeds of race hate to be planted under the sanction of law. What can more certainly arouse race hatred, what more certainly create and perpetuate a feeling of distrust between these races, than state enactments, which, in fact, proceed on the ground that colored citizens are so inferior and degraded that they cannot be allowed to sit in public coaches occupied by white citizens? That, as all will admit, is the real meaning of such legislation as was enacted in Louisiana."257

\section{An Analysis of Harlan's Constitutional Philosophy on Civil Rights \\ The Relation of His Civil Rights Views to His Basic Judicial Position}

Any attempt to analyze and evaluate the position taken by a Justice in one separate area of constitutional law is a venture which usually results in reconvincing the evaluator that law is a seamless web. Not only do the cases resist classification in a single category, but the closer the examination, the more apparent it is that the Justice's approach was affected by the doctrinal commitments he made in cases involving quite different subjects, as well as by his personal relations with fellow Justices and his conception of the proper role for the Supreme Court as an institution. This was true and yet not true with respect to Harlan's civil rights position. As the earlier section demonstrates, the cases presented not simply questions of civil liberty and equality before the law but delicate problems concerning interstate commerce, state trial practice, federal due process, federal jurisdiction over private acts, and

256. Id. at $562-63$.

257. Id. at 560. Harlan also dissented, without opinions, in Chesapeake \& O. Ry. v. Kentucky, 179 U.S. 388 (1900), upholding a state prosecution of a railroad for failing to separate the races, and Chiles v. Chesapeake \& O. Ry., 218 U.S. 71 (1910), in which the court upheld segregation by a railroad company during the Southern portion of an interstate trip on the ground that, in the absence of a congressional rule, the carrier could reasonably separate white and Negro passengers.

There were two other cases involving Negroes during Harlan's service' on the Court. In United States v. Shipp, 203 U.S. 563 (1906), the Court ordered a contempt trial for a sheriff who had assisted a mob to lynch a Negro prisoner, after the United States Supreme Court had issued a stay of execution and the case was about to be heard. Harlan, who had been the Justice to grant the petition for stay, in the first instance, joined the Court in the contempt ruling. In Marbles v. Creecy, 215 U.S. 63 (1909), an extradition case, a Harlan opinion for the Court held that the executive of a state, in the absence of proof, did not have to assume that a Negro accused of crime in a Southern state would not receive a fair trial. 
other complicated matters that intruded themselves into the Court's consideration of white-Negro relations. On all of these separate problems, Harlan had made strong commitments. Yet these did not especially control his reaction in civil rights cases. For example, Harlan's strong dissenting opinions in cases dealing with indictment by grand jury, ${ }^{258}$ the privilege against self-incrimination, ${ }^{259}$ trial by jury, ${ }^{260}$ ex post facto laws ${ }^{261}$ and protection against cruel and unusual punishment ${ }^{262}$ represented the views of a man fervently devoted to the maximum standards of fair procedure for defendants in state and federal trials. Yet, in Clyatt $v$. United States, ${ }^{263}$ the fact that the two defendants were white men who had committed "barbarities" against Negroes led Harlan to brush aside the presence of a plainly defective indictment with the argument that the defendants had failed to object before the case went to the jury, a position it is inconceivable to imagine Harlan taking if the Negro issue had not been present.

This is not to suggest that Harlan would go to any lengths or ignore all legal and constitutional boundaries when Negro petitioners came before the Court. While Harlan had defended the rights of Negroes to serve on juries during his Kentucky days, and his opinions show that he felt at least as strongly in favor of nondiscriminatory juries as he did in favor of nondiscriminatory trains or inns, he did not dissent from a single one of the Court's rulings denying reversals of conviction because of failure to produce concrete evidence of jury discrimination. ${ }^{264}$ Harlan would not assume discrimination from statistics showing the complete absence of Negroes from juries; nor could he bring himself to urge that the Court read out of Congress's removal statute its requirement that the discrimination necessary for removal of cases to federal court arise out of the constitution or laws of a state, not local practice.

Relations with his colleagues played a remarkably small part in shaping Harlan's opinions, on civil rights or otherwise. With a delightful sense of humor and Southern affability, Harlan was on good personal terms with his fellow Justices. But the spirit of compromise-of adjusting opinions and submerging differences to produce a corporate product-never appealed to Harlan when he held strong moral and political views toward a subject. ${ }^{265}$ When his deepest

258. Maxwell v. Dow, 176 U.S. 581, 605 (1900) ; Hurtado v. California, 110 U.S. 516, 538 (1884).

259. Twining v. New Jersey, 211 U.S. 78, 114 (1908).

260. Schick v. United States, 195 U.S. 65, 72 (1904). And see Harlan for the majority in Thompson v. Utah, 170 U.S. 343 (1898).

261. Hawker v. New York, 170 U.S. 189, 200 (1898).

262. O'Neil v. Vermont, 144 U.S. 323, 366 (1892). For other cases illustrating Harlan's concern for procedural fairness see Trono v. United States, 199 U.S. 521,535 (1905) (dissenting opinion) ; Hawaii v. Mankichi, 190 U.S. 197, 226 (1903) (dissenting opinion); Campbell v. Holt, 115 U.S. 620, 630 (1885) (concurring in dissenting opinion).

263. 197 U.S. 207, 222 (1905) (dissenting opinion).

264. See notes 219 and 220 supra and accompanying text.

265. Chief Justice White noted in his inimitable prose:

"His methods of thought, in disregard of mere subtleties or refined distinctions, led him to the broadest lines of conviction, and as those lines were by him discerned, 
principles were at issue, he pounded the table at conference, thundered at the strange obtuseness of his brothers, shook his finger at the Court while delivering dissents in open court, and rarely used a soft phrase in his opinions if a striking and sharp one occurred to him. Perhaps the best description of this characteristic came from Harlan himself. Describing "Kentuckians" at a banquet in 1905, Harlan painted this picture, which was obviously drawn as his personal ideal :

"[Kentuckians] ... have, and have always had, the courage of their convictions. It can always be known where they stand. What they undertake is pressed to accomplishment with all their might. What they believe is believed by them with their whole heart. They are not a half-way people. They are not indirect in their methods. They are without deceit. They are outspoken and manly. They despise injustice. They will not willingly. submit to wrong, and will resist to the utmost what they deem to be wrong. I do not say that these qualities are absent from other peoples. But I do say, with some feeling of pride, that these qualities are to be found among the people of Kentucky in a high degree."266

Harlan's conception of the judicial function fitted in very conveniently with his policy views as to civil rights. In general, Harlan was a strong opponent of what he called "judicial legislation." From his first dissenting opinion as a Supreme Court Justice ${ }^{207}$ to the last dissent he wrote, ${ }^{268}$ Harlan

and differences between himself and others became impossible of reconciliation, the warfare of mind with mind was by him carried on, not with adroit fence or subtle play of reason, but with a directness and entire disregard of all narrower points of view. This was particularly observable with reference to his conclusions on questions concerning powers of government arising from constitutional limitations and the consideration of asserted violations of the rights of individuals protected by such limitations."

Procedings on the Death of Mr. Justice Harlan, 222 U.S. xxvii (1912).

266. J.M.H., Response to Toast, "MIy Old Kentucky Home," Remarks of Mr. Justice Harlan at Banquet Given by Loutisville Bar Ass'n, June 1, 1905, Harlan Papers, Author's Possession.

267. United States v. Clark, 96 U.S. 37, 44, $46-47$ (1878) (dissenting opinion):

"The will of Congress as to the conditions upon which it allows the citizen to sue the government has been expressed in plain and unambiguous language, which leaves no room for construction. It is obviously our duty to execute the statute without reference to our opinion as to its wisdom or policy. If, under the circumstances of particular cases, it seems harsh when construed according to its terms, the remedy is with another department of the government, and not with the judiciary. ... With entire respect for the opinion of my brethren, I submit that the construction which the court places upon the act ... seems to fall very little short of judicial legislation."

268. United States v. American Tobacco Co., 221 U.S. 106, 189 (1911) (dissenting opinion). In the companion antitrust case, Standard Oil Co. v. United States, 221 U.S. 1, 82, 105 (1911) (dissenting opinion), Harlan looked back on his long career as a Supreme Court Justice and remarked :

"After many years of public service at the National Capital, and after a somewhat close observation of the conduct of public affairs, I am impelled to say that there is abroad, in our land, a most harmful tendency to bring about the amending of 
maintained that the Court should not rewrite congressional enactments to fit its own conception of right policy, nor should the Court interpret the Constitution in such a way as to place unwise and uncalled-for limits on national legislative authority. Since most of his civil rights dissents were in cases where the Court declared federal civil rights acts unconstitutional or interpreted the War Amendments in a way different from what Harlan felt the framers had intended, Harlan's main dissenting posture was that of a man calling upon the Court to stay in its proper place and to stop acting like a super-legislature. At the same time, however, Harlan had another maxim which guided his approach as a Justice-in the protection of life, liberty and property it was the function of the Supreme Court to safeguard the citizen from government aggressions, by which he meant the actions of the executive and administrative authorities of the national and state governments. A clear statement of his attitude was made in a case where the Court had, because of the immunity of the United States from suit, dismissed the appeal of a patentee whose rights had been infringed by a United States postmaster. ${ }^{269}$ Harlan protested:

"I am of the opinion that every officer of the government, however high his position, may be prevented by injunction, operating directly upon him, from illegally injuring or destroying the property rights of the citizen. . . . In my judgment it is not possible to conceive of any case, arising under our system of constitutional government, in which the courts may not, in some effective mode, and properly, protect the rights of the citizen against illegal aggression, and to that end, if need be, stay the hands of the aggressor, even if he be a public officer, who acts in the interest, or by the direction of the government."270

Under this part of his judicial philosophy, Harlan could be found demanding that the Court do substantive justice, whether the injured party was a Negro seeking to cast his vote in an Alabama congressional election, ${ }^{271}$ a liquor dealer, ${ }^{272}$ a resident Chinese alien, ${ }^{273}$ a patentee, ${ }^{274}$ a merchant seaman, ${ }^{275}$ the holder of a government bond, ${ }^{276}$ or an Indian. ${ }^{277}$ If a solid legal ground was available to support a "just" result, Harlan would urge it with vigor. If not,

constitutions and legislative enactments by means alone of judicial construction. ... To overreach the action of Congress merely by judicial construction, that is, by indirection, is a blow at the integrity of our government system, and in the end will prove most dangerous to all."

269. International Postal Supply Co. v. Bruce, 194 U.S. 601, 606 (1904) (dissenting opinion).

270. Id. at 616-17.

271. Giles v. Harris, 189 U.S. 475, 493 (1903) (dissenting opinion).

272. O'Neil v. Vermont, 144 U.S. 323, 366 (1892) (dissenting opinion).

273. Baldwin v. Franks, 120 U.S. 678, 694 (1887) (dissenting opinion).

274. Belknap v. Schild, 161 U.S. 10, 27 (1896) (dissenting opinion); Schillinger v. United States, 155 U.S. 163, 172 (1894) (dissenting opininon).

275. Robertson v. Baldwin, 165 U.S. 275, 288 (1897) (dissenting opinion).

276. Louisiana v. Jumel, 107 U.S. 711, 746 (1883) (dissenting opinion); Antoni v. Greenhow, 107 U.S. 769, 801 (1883) (dissenting opinion).

277. Elk v. Wilkins, 112 U.S. 94, 110 (1884) (dissenting opinion). 
it was a rare "outrage" case in which Harlan would not urge a less-than-solid ground with all the vigor that his moral indignation unfailingly supplied. In this respect, Harlan stood in the classic pattern of those who espouse judicial self-restraint on behalf of majority rule but are so devoted to civil liberty that they cannot always restrain themselves. The difference between Harlan and the modern majoritarians, of course, is that Harlan considered the rights of liberty and property to be twin values, and with the perspective of Locke and Clay could see no distinction between "money matters" and "freedom matters."278

\section{The Psychological Bases of Harlan's Civil Rights Opinions}

Vith these comments as preliminary ground work, Harlan's approach to civil rights cases and the arguments he applied in them can now be analyzed. Harlan participated in thirty-nine cases that dealt with the civil rights of Negroes in the United States. In every case where the Supreme Court upheld the claimed rights of Negro petitioners, Justice Harlan was with the majority. In every case where the Court declared federal civil rights legislation to be unconstitutional or unconstitutionally applied, Justice Harlan dissented. In every case in which the majority interpreted the War Amendments or the civil rights acts to permit discrimination based on race, or enunciated rules of procedure which left civil wrongs proved by Negro suitors uncorrected, Justice Harlan expressed his disagreement with the decision. In a majority of these dissents Harlan stood alone.

Just why Harlan gave such undeviating support to Negro civil rights is worth probing. It is true that he had been an exponent of the Republican procivil-rights position during the Kentucky campaigns of the 1870's. But, freed from the practical necessities of Republican politics, he could have reverted to the outlook of a Southerner or become a border-state moderate. He could have swung close to the civil rights approach of such stalwart Northern Republicans on the Court as Blatchford, Gray and Bradley. As we have seen, he did none of these but, instead, became the most fervent Republican of them all.

278. For samples of Harlan's views on freedom of contract, see Adair v. United States, 20 S.S. 161 (1908), and Hooper v. California, 155 U.S. 648, 659 (1895) (dissenting opinion); on deprivation of property rights by rate regulation, see Smyth v. Ames, 169 U.S. 466 (1898), and Stone v. Farmers' Loan and Trust Co., 116 U.S. 307, 337 (1886) (dissenting opinion) ; on legislative power to take private property or infringe on owner's freedom, see Chicago, B. \& Q.R.R. v. Chicago, 166 U.S. 226 (1897), and Greer v. Connecticut, 161 U.S. 519, 542 (1896) (dissenting opininon); and on procedural alterations of property rights which seemed to him "sheer spoilation under the forms of law", see Freeland v. Williams, 131 U.S. 405, 420 (1889). Harlan's approach toward private property and government regulation, alternating between the Fieldian basso of his Adair case opinion and his Holmesian refrain in Atkins v. Kansas, 191 U.S. 207 (1905), was based on an unusual and complicated attitude which will be treated in another article, John Marshall Harlan and the Rights of Property: A Whig-Progressive in the Age of Enterprise. 
The explanation of Harlan's position is that the Negro issue was not a minor or occasional theme in his life; it had run like a leitmotif through his Kentucky career. The slavery controversy had confronted him when he first entered manhood and, splitting the Whig Party, had sent him to his short-lived adventure as a Know-Nothing. The inability of North and South to compromise on the slavery conflict had forced John Harlan to choose between Southern mores and national loyalty, a decision which had impelled him into the Union lines at Castillian Springs and LaVergne. Back in Louisville in the mid-1860's, it was the Negro issue which collapsed Harlan's Constitutional Union Party, as the struggle over emancipation and reconstruction polarized Kentucky politics into confederate and radical parties.

Once the War Amendments had given the Negro status as a human being, Harlan had been compelled to re-examine his property-rights, states-rights objections to Negro legal equality. Having joined the Republican Party, Harlan tried to place the Negro issue to one side and win office on a forwardlooking economic reform platform, only to find that the passions over the War and its civil rights results kept the Negro question at the heart of Kentucky politics. By now, Harlan was a pro-civil-rights spokesman, meeting on equal personal terms with Negro leaders in Kentucky and throughout the country, maintaining only those reservations natural to a man who appreciated the immensity of the interracial problem in a Southern state in the 1870's. Even after his move to Republicanism, though, the Negro issue rose to shake Harlan's life again, when charges against the authenticity of his new civil rights stand became one of the issues that threatened to block his confirmation as a Supreme Court Justice.

When Harlan joined the Court in 1877 , then, he arrived as a man whose most vivid experience apart from battle had been his conversion on the civil rights issue. To justify his basic shift in philosophy in 1868, Harlan had convinced himself that he had been wrong-completely and dangerously wrongin his earlier pro-slavery views. From 1868 to 1877 , in hundreds of campaign speeches from Maine to Kentucky, Harlan had proclaimed his mea culpa, and he arrived on the Court fresh from defending the orthodoxy of his civil rights faith before a congressional committee. Thus, just as a religious or political convert will hold his faith more strongly, even more combatively, than the born believer, so Justice Harlan had become a staunch supporter of Negro civil rights, a man who could write to his law partner in 1895: "My whole nature responds to the principle of equality of all men before the law. . ."270 The fact that the Southern Democratic Party was behind the anti-Negro legislation upon which Harlan passed made his civil rights faith burn even brighter, since Harlan went to his grave confident that "all the elements of disorder and lawlessness are to be found in the Democratic plans and policies. . . 280

279. Letter from J.M.H. to Augustus Willson, undated, probably 1895, Harlan Papers, Lonisville.

280. Letter from J.M.H. to Augustus Willson, July 17, 1908, Wilson Papers, Filson Club, Louisville, Kentucky. 
In addition, as the years went by, Harlan came to associate his warm personal memories of the Civil War with the cause of the Negro, so that he could describe the conflict of $1861-65$ as the time when "slave property sought to dominate the freeman of America. ..."281 Similarly, the violence of the irreconcilables which produced the conspiracy cases was the very lawlessness which Harlan had fought in the political campaigns of 1871 and 1875. In short, Harlan felt that Southern efforts to dominate the Negro by legal, political and terrorist means were only a paler substitute for the chattel ownership he had come to regret. These were the thoughts which Harlan examined and deepened on the bench, where the absence of rough-and-tumble politics and violence gave him time to assimilate his attitude toward Negroes into the moral and political fundamentalism that was his basic framework.

\section{Harlan's Civil Rights Doctrines Analyzed}

Harlan's civil rights position as a Justice is reflected in the two issues which most concerned the Court in this period: congressional power over private discriminatory acts, as involved in the Civil Rights Cases, Hodges and Clyatt; and the validity of state segregation laws, as presented by Plessy, Cumming and Berea College.

\section{The Reach of Congressional Power Under the War Amendments}

Of all his opinions, Harlan himself "set most store" by his Civil Rights Cases dissent, 282 a choice he made from 772 written opinions for or with the Court and 137 written dissents. ${ }^{283}$ As a stirring essay on behalf of human liberty and in protest against racial intolerance, the dissent is justly famous. As an exercise in constitutional interpretation and judicial logic, however, the opinion combines both praiseworthy and indefensible arguments, a fact which is too often ignored by commentators who share Harlan's egalitarian sentiments.

Certainly, Harlan's argument was sound against the Court's disregard of an interstate commerce ground to support the application of the act of 1875 to discrimination by interstate railroads ; ${ }^{284}$ and in fact, the 1930 's produced a return to the permissive standard of review upon which Harlan insisted. Also, Harlan's description of the "state instrumentality" character of railroads and inns, if not theaters also, ${ }^{285}$ is a defensible position toward which the federal courts have moved steadily in cases holding white primaries, ${ }^{286}$ company towns, ${ }^{287}$ semi-

281. Letter from J.M.H. to Augustus Willson, June 1, 1895, Harlan Papers, Louisville. 282. Eleventh Annual Proceedings of the Kentucky State Bar Ass'n, July $10-11,1912$, at 37 (1912).

283. During his thirty-four years on the Court, Harlan participated in 14,226 cases. He delivered the opinion of the Court in 745 cases, wrote concurrences in 27 and joined the majority in 13,074 . He delivered 137 written dissents, concurred in the dissenting opinions of other members of the Court in 82 cases and dissented without opinion in 161 other cases.

284. See text at p. 680 supra.

285. Ibid.

286. Terry v. Adams, 345 U.S. 461 (1953); Smith v. Allwright, 321 U.S. 649 (1944).

287. Marsh v. Alabama, 326 U.S. 501 (1946). 
private libraries, ${ }^{288}$ judicially enforced restrictive covenants ${ }^{289}$ and discrimination by lessees from the state ${ }^{290}$ to present state action. It may be that Harlan's position as to public accommodation facilities still stands beyond the modern rule, if one assumes that the essential feature today is that the function is one in which the state participates directly or which it would normally perform itself but has left to private hands. The extension of the doctrine to cases where the state gives substantial aid and employs governmental power to assist public accommodation operators is not unlikely, however, and, if made, would bring the law to the exact point of Harlan's dissent.

On the other hand, Harlan's position as to congressional power under the citizenship sentence of the Fourteenth Amendment and his reading of the Thirteenth Amendment's ban on the restoration of slavery cannot be rated as highly, even from the expansive constitutional vistas of the 1950's.

First, Harlan argued that the citizenship sentence of the Fourteenth Amendment gave Congress, under the grant of enforcement power in section five, the authority to forbid private acts of discrimination. The difficulty with his position is that it runs counter to the legislative history and the language of section one, not in the sense that Harlan supported a broad but true reading as against an "artificial" and "over-narrow" one, but in the sense that Harlan's view misconstrued what the real content of the Fourteenth Amendment was. ${ }^{201}$ In the early stages of congressional debate over the proposed amendment, the Joint Committee on Reconstruction reported to the House a draft written by Representative John Bingham which would have given Congress power to make all laws necessary and proper "to secure to the citizens of each State all privileges and immunities of citizens in the several States, and to all persons in the several States equal protection in the rights of life, liberty and property."20: Representative Bingham and several other Republicans defended this proposal as doing nothing more than restating various guarantees already in the Constitution, citing article IV, section 2 and the Fifth Amendment; the amendment would add, they said, "the express grant of power upon the Congress" to enforce the guarantees. ${ }^{293}$ This immediately drew attacks from moderate and radical Republicans, ${ }^{294}$ as well as a Democratic spokesman, ${ }^{295}$ all objecting to the draft

288. Kerr v. Enoch Pratt Free Library, 149 F.2d 212 (4th Cir. 1945).

289. Barrows v. Jackson, 346 U.S. 249 (1953) ; Hurd v. Hodge, 334 U.S. 24 (1948); Shelley v. Kraemer, 334 U.S. 1 (1948).

290. Muir v. Louisville Park Theatrical Ass'n, 347 U.S. 971 (1954) ; Tate v. Department of Conservation and Development, 133 F. Supp. 53 (E.D. Va. 1955), aff'd, 231 F.2d 615 (4th Cir. 1956), cert. denied, 25 U.S.L. WEEK 3104 (U.S. Oct. 8, 1956) (No. 238).

291. It is important to note that it is the intent and execution of the framers of the Fourteenth Amendment in 1866 that is the critical issue here, not the intent of Congress in 1871 or 1875 when enforcement acts were adopted.

292. Cong. Globe, 39th Cong., 1st Sess. 1033-34 (1866).

293. Bingham, $i d$. at 1034. For others expressing a similar view, see William Higby of California, $i d$. at 1054-56; William D. Kelley of Pennsylvania, id. at 1057-63; Hiram Price of Iowa, $i d$. at 1066-67; Frederick E. Woodbridge of Vermont, id. at 108s.

294. Robert S. Hale of New York, id. at 1063-66; Thomas T. Davis of New York, id. at 1083-87; Giles W. Hotchkiss of New York, id. at 1095.

295. Andrew J. Rogers of New Jersey, id., app. 133-40. Another Democrat, Samuel 
as giving too much power to Congress. In the most carefully reasoned speech of the debates, Republican Robert Hale of New York warned his colleagues:

"It is not a mere provision that when the States undertake to give protection which is unequal Congress may equalize it; it is a grant of power in general terms-a grant of the right to legislate for the protection of life, liberty, and property, simply qualified with the condition that it shall be equal legislation." 296

This, Hale felt, would be "an utter departure from every principle ever dreamed of by the men who framed our Constitution." 297 When questioned directly by Hale as to whether this was the effect of his draft, Bingham hedged back and forth but admitted, "I believe it does in regard to life and liberty and property...."208 On that ground, Roscoe Conkling rose to table the Bingham draft, saying that he had opposed the idea in committee and opposed it now. ${ }^{299}$ Bingham's proposal was tabled and it was never presented to the House or the Senate again. ${ }^{300}$ When the successor draft of the Fourteenth Amendment, framed in terms of "no state," was debated, none of the critics of the Bingham proposal attacked the provision as being the same concept in disguise, a position men like Hale and certainly Rogers would have been quick to assert if the adopted draft had been so understood in Congress.

As to citizenship, a sentence was added to the adopted draft, from the floor, stating simply that "all persons born or naturalized in the United States, and subject to the jurisdiction thereof, are citizens of the United States and of the State in which they reside," a sentence included to reverse the Dred Scott holding that Negroes were not citizens. ${ }^{301}$ If this sentence had been written as a section by itself and had been left unmodified, there might be a defensible

J. Randall of Pennsylvania, also spoke in opposition to the Bingham draft, but on the ground that no amendment should be passed while eleven states were unrepresented in Congress. Id. at 1057.

296. Id. at 1063-64.

297. Id. at 1063. For Rep. Davis's opposition to such "centralization of power in Congress in derogation of constitutional limitations," see in particular id. at 1087; for Rep. Hotchkiss's statement that he was "unwilling that Congress shall have any such power," see $i d$. at 1095 .

298. Id. at 1094 .

299. Id. at 1094-5.

300. The vote was on Rep. Conkling's motion to table the Bingham draft until the second Tuesday in April. Seeing their leadership facing a defeat, Bingham and his supporters joined the vote to table, producing a 110 to 37 majority. For press comment showing that this vote was understood publicly as a defeat for the Bingham concept, see Fairman, Does the Fourteenth Amendment Incorporate the Bill of Rights? The Original Understanding, 2 StAN. L. REv. 5, 37 \& n.66 (1949).

The discussion of the Fourteenth Amendment in this Article adopts the same position taken by Professor Fairman in the article just cited, by White, The Life of LyMaN Trumbuln 282 (1913), and by Bickel, The Original Understanding and the Segregation Decision, 69 Harv. L. Rev. 1 (1955).

301. Senator Jacob Howard of Michigan in reporting the citizenship sentence to the floor, stated: "This amendment which I have offered is simply declaratory of what I regard as the law of the land already. . . . It settles the great question of citizenship 
argument on the basis of ambiguous language that Congress had meant to do more than specify who were citizens. But the citizenship definition was added by the Republican leadership as the first sentence in a section which went on to declare, immediately following, that no state should abridge the privileges and immunities of national citizens. Read in terms of plain language or of legislative history, then, the "no state" sentence refutes the idea that the citizenship sentence had been intended by the framers to give Congress authority to punish private action, unless one is to accept the remarkable theory of Professors Flack ${ }^{302}$ and ten Broeck ${ }^{303}$ that the sharp alterations of language in the several drafts of the Fourteenth Amendment made no constitutional difference, the framers being all pro-civil-rights men. This argument, of course, ignores the Republican opposition to Bingham's proposal and mistakes the recorded understanding of Congress and the ratifying states ${ }^{304}$ that in the course of the debate over the Fourteenth Amendment congressional jurisdiction over private discrimination had been abandoned.

In defense of his reading of the citizenship sentence, Harlan cited the preWar cases of Prigg ${ }^{305}$ and Ableman, ${ }^{306}$ where the Court had upheld the operation of national fugitive slave legislation on private persons despite language in the supporting constitutional provision, article IV, section 2, referring to "any law or regulation" which interfered with recapture. Since the Court had not limited congressional power in protecting the master's rights, Harlan felt, the Court should not adopt a narrower rule for the amendment bestowing citizenship rights on the former slaves. The obvious answer to this is that the Constitution had not dealt with the rights of masters and of new citizens in identical terms. In order to put through Congress and the states a protection against state infringement of citizenship rights, the civil rights supporters had been forced to drop the clause which might have upheld congressional control over private discrimination; article IV, section 2 was unmarred by such legislative history or by clear language against a private action interpretation. Thus, while the Prigg and Ableman decisions were themselves extreme, Harlan's reasoning if adopted would have done even more violence to constitutional interpretation.

Harlan's argument that the Thirteenth Amendment's ban on slavery and involuntary servitude supported Congress's power over private discrimination had more to recommend it, but not as it was applied in the Civil Rights Cases. The majority and Harlan had agreed that the intention and effect of the Thirteenth Amendment had been to create "universal freedom" for the Negro,

and removes all doubt as to what persons are or are not citizens of the United States." Cong. Globe, 39th Cong., 1st Sess. 2890 (1866).

302. Flack, The Adoption of the Fourteenth Amendient (1908).

303. ten Broex, The Antislavery Origins of the Fourteenth Amiendaent (1951).

304. For a careful analysis of the ratification debates, see Fairman, supra note 300 , at $81-132$.

305. Prigg v. Pennsylvania, 41 U.S. (16 Pet.) 539 (1842).

306. Ableman v. Booth, 62 U.S. (21 How.) 506 (1859).

307. 109 U.S. at 20. 
and that the enforcement clause in section two gave Congress power to protect freemen against the "incidents of slavery," whether imposed by state or private actions. ${ }^{308}$ The dispute between the majority and minority turned on what rights inhered in the state of freedom from slavery. As in the structure of the Fourteenth Amendment debates, a proposal had been introduced during the debates on the Thirteenth Amendment by Senator Charles Sumner of Massachusetts which would have given "equality of all persons before the law" as the definition of freedom from slavery. Sumner, cautioning his colleagues that they should be conscious of what language they chose, argued that his draft embodied the tradition of the French Declaration of Rights and represented the ideal terms in which to abolish slavery. ${ }^{309} \mathrm{He}$ was opposed by the Chairman of the Senate Judiciary Committee, which had reported out the draft as later adopted. Senator Lyman Trumbull of Illinois noted that such alternatives had been discussed and rejected in committee and called on Sumner to withdraw his amendment. ${ }^{310}$ Another member of the Committee, Senator Jacob Howard of Michigan, made the same point and added that the Committee had taken its language from the Northwest Ordinance of 1787, a "good old Anglo-Saxon" expression which was well understood by judicial tribunals and the public. ${ }^{311}$ If this means anything, it means that the Committee intended no political and civil rights to be included in the amendment's scope, since under the Northwest Ordinance, Negroes had acquired no political and civil rights with their freedom from slavery. ${ }^{312}$ Sumner, seeing that there was no support for his attempt to broaden the language of the amendment, withdrew his proposal. ${ }^{313}$

During the main phase of the debates, only one speaker, an opponent of the amendment, claimed that it would confer political rights on the Negro and give Congress the right to "invade" the states to "enforce" that freedom. ${ }^{314}$ This rhetorical outburst was not even answered by the amendment's supporters, who were busy defending the power of Congress to propose an amendment taking private property without compensation and touching a subject which was claimed to be a matter of state jurisdiction alone. In the ratification process, three Southern states which ultimately ratified the amendment were troubled by the possibility that the second section bestowing enforcement power on

308. Id. at 20-21.

309. Cong. Globe, 38th Cong., 1st Sess. 1482-83, 1487-88 (1864).

310. Id. at 1488 .

311. Id. at $1488-89$.

312. Hamilton, The Legislative and Judicial History of the Thirteenth Amendment, 9 NAT'L B.J. 26, 52 (1951):

"It was universally understood that Article VI [of the Northwest Ordinance] did not confer any political or civil rights on Negroes. The free Negro's status in the Northwest was only slightly better than that of a slave. He was obliged to exist on the fringe of settlements, denied access to schools, the courts, and the polls, and regulated by the Black Codes taken from the statute books of slaveholding states."

313. Cong. Globe, 38th Cong., 1st Sess. 1488 (1864).

314. William S. Holman of Indiana, id. at 2962. 
Congress might be construed to give Congress power to legislate upon individuals to enforce political and civil rights of Negroes. ${ }^{315}$ The Provisional Governor of South Carolina wired President Johnson to inquire about this and received the following reply from Secretary of State William Seward: "The objection which you mention to the last clause of the constitutional amendment is regarded as querulous and unreasonable, because the clause is really restraining in its effect, instead of enlarging the powers of Congress."310 Accepting this as the official executive construction, Florida, Alabama and South Carolina each placed in their official ratifications a statement that any congressional legislation upon the political rights of former slaves would be contrary to the proposed amendment, just to make sure that the point was beyond dispute. ${ }^{317}$ The ratifications were not rejected as embodying an inconsistent understanding.

If this were the end of it, Harlan might still have had a defensible position. But, as we have noted, the members of the Thirty-Eighth and Thirty-Ninth Congresses were worried about the constitutionality of their Civil Rights Act of 1866 and they decided not to leave the Negro's status to the tender mercies of the courts. Taking hold of the issue once again, they debated another amendment to spell out the political rights of citizens and, in the process, adopted the compromise discussed earlier. After the ratification of the Fourteenth Amendment, that instrument was the source of the citizenship rights of $\mathrm{Ne}$ groes; what remained untouched in the Thirteenth was solely congressional power to protect the rights which inhered in the state of freedom from slavery.

Bradley's opinion, looking to the history of slavery and its understanding by the framers, found, as the well-known "incidents of slavery,"318 such items as compulsory service, restraint on movement, disability to hold property or to contract, severer penalties for crimes committed and the barring of slave testimony against whites. To Harlan's argument that the denial of accomodations to Negroes was also an imposition of the "badges of slavery," Bradley answered that, if these were discriminations the law could recognize, they were aimed at excluding a racial group, not imposing slavery; like discriminations against members of religious faiths or economic classes, these would

315. Thorpe, Constitutional History of the United States 157-232 (1901); Hamilton, supra note 312 , at $39-48$.

316. Hamilton, supra note 312 , at 45 . What Seward meant by saying that the last clause restrained Congress is not clear, at least to this writer.

317. THORPE, op. cit. supra note 315, at 200-01, 202-10, 217-20; Hamilton, supra note 312 , at $45-46$. The Louisiana legislature adopted a similar resolution in its ratification proceedings but did not embody the resolution in its instrument of ratification. THORPE, op. cit. supra note 315 , at $159-60$.

318. During the debates only one speaker, Sen. James Harlan of Iowa, detailed the "incidents of slavery" which the amendment would wipe out. He was so obviously spealing in the large that his comments do not help to fix the meaning of that term; included in his list of "incidents" were the suppression of free speech and press rights of slaves and whites opposing slavery, the denial of education to poor whites in the South, and the economic impoverishment of the slave states. Cong. Giobe, 38th Cong., 1st Sess. 1439-40 (1864). 
be denials of citizenship rights. If done by the state, Bradley said, they could be punishable under the state action provisions of the Fourteenth Amendment; if done by private persons, they were punishable only by the states.

To fix the exact point at which, in this writer's opinion, Harlan's argument failed to apply, it should be observed that Harlan's reading of the Thirteenth Amendment was sound in the Clyatt and Hodges cases. In Clyatt, leaving aside the "returning" complication, Harlan maintained that physical coercion to compel Negroes to work out a pre-existing debt would represent a holding in involuntary servitude ${ }^{310}$ in Hodges, his dissent took the same view of a conspiracy by the "Whitecappers" in Arkansas to drive all Negroes from "white man's work," a forceful interference with the right of Negroes to work for a willing white employer. ${ }^{320}$ Since the right to dispose of one's labor by contract can fairly be said to inhere in freedom from slavery, Harlan was right in these cases, and the Court recognized this in part in the second Bailey case. ${ }^{321}$ Since discrimination in the enjoyment of public accommodation facilities is not on the same footing under the Thirteenth Amendment, Harlan's argument carried too far in that instance.

Viewed as a whole in its contemporary setting, Harlan's Civil Rights Cases dissent did two useful things: it placed before the nation a passionate protest against the exercise of private segregation and it demonstrated that, if the Court had been interested in sustaining a good part of the act of 1875, there were sound constitutional bases on which that could have been accomplished. In his reading of the War Amendments and private discrimination, Harlan failed to carry the Court and contemporary public opinion. Seventy-four years later, despite the writings of a score of pro-Harlan scholars, Harlan's views still have not impressed the Supreme Court, nor should they; honest and wellintentioned as they were, they rest upon a misreading of language and of legislative history which, if adopted as the proper technique, would confuse and stultify the interpretive process.

\section{Racial Segregation Laws and the Fourteenth Amendment}

The lasting significance of Harlan's civil rights position, happily, does not rest on the over-extended portions of his 1883 dissent (or even on his solid "state action" analysis in that case) but rather on his powerful exposition of the unconstitutionality of state segregation laws under the equal protection clause. After 1883, as C. Vann Woodward has impressively demonstrated, ${ }^{322}$ there was no sudden deluge of privately imposed Jim Crow measures or racial aggression in the South. The Solid South remained in the governmental hands and under the social dominance of the Democratic white "conservatives," who gave Negroes minor political posts and generally decent treatment (as inferiors, to be sure) in return for votes. A race-conscious Negro journalist visiting the

319. See text at pp. 687-8s supra. This was also the view of the majority.

320. See text at p. 688 supra.

321. See text at p. 689 supra.

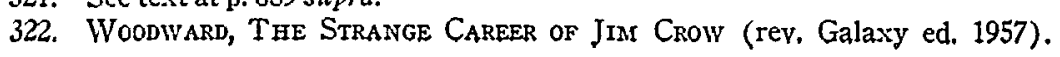


South in 1885 reported, to his great surprise, that Negroes usually sat alongside whites in railroad cars in Virginia and dined in the same room aboard steamboats in Delaware and North Carolina; in his tour of Delaware, Maryland, Virginia, the Carolinas, Georgia and Florida, the reporter found Negroes everywhere eating, drinking and traveling alongside whites. ${ }^{323}$ In addition, Negroes were voting in large numbers in every Southern state and were serving in lesser appointive and elective positions-state legislators from predominantly Negro counties, jury commissioners, trial justices and local federal employees such as postmasters. The Negro paid for this by supporting the "Bourbons" against the occasional Republicans and the mass of "Rednecks." 324 As of the 1880 's, then, enforced legal segregation or socially-dictated private segregation was not the Southern rule and did not follow directly from the Civil Rights Cases. ${ }^{325}$

A wide variety of social forces were moving the South away from the dominance of the conservatives and toward a policy of total segregation. In the South the political swing from Bourbon rule to the rule of agrarian radical regimes which followed the agrarian depressions of the 1890's, meant defeat for the influence of the conservatives in race policy; disillusioned Populists like Tom Watson became convinced that the Negro was a tool of the Bourbons and dropped their egalitarian racial views to become violently anti-Negro; "redneck" leaders like Pitchfork Ben Tillman and James K. Vardaman became fellow-spokesmen for a philosophy that rested in equal parts on white supremacy and anticapitalist progressivism. In the North the Republican Party did not need Southern Negro votes for its continued domination of the presidential office, and it lost its practical interest in Negro rights. General Northern proNegro sentiment had receded under the impact of new industrial conflicts, the rise of laissez-faire social philosophy, and imperialist adventures that resulted in American rule over "inferior" native populations. The resultant victory of the Jim Crow policy in the 1900's was therefore not so much the triumph of lower-class anti-Negro sentiment, which had always been present,

323. Id. at 19-22. This Conservative-Negro cooperation applied in the states of the South which, unlike Kentucky, were one-party Democratic areas. Where there was a strong Republican Party, Negro votes tended to support it.

324. In addition to WoODWARD, op. cit. supra note 322 , this account is drawn from Johnson, The Developdent of State Legislation concerning the Free Negro (1919); Lewinson, Race, Class, \& Party, A History of Negro Suffrage and White Politics in the South (1932) ; Mabry, The Negro in North Carolina Politics since Reconstruction (1940) ; Morton, Tee Negro in Virginia Politics, 1865-1902 (1919); Tindall, South Carolina Negroes, 1877-1900 (1952); Wardlaw, Negro Suffrage in Grorgia, 1867-1930 (33 Bulletin of the University of Georgia No. 2a, 1932); Wharton, THE NEGRo IN MrssissipPI, 1865-1890 (1947).

325. It is significant that Harlan left Kentucky and joined the Supreme Court at a time when large-scale segregation was not the pattern in Kentucky or the South generally, and the socio-political setting promised racial amity in the use of public facilities if the "poor white" extremists could be controlled. This had the effect of freezing Harlan's views at the hopeful levels of the 1870's and spared him the re-examination of possibilities which his fellow moderates had to make in the 1890's and 1900's. 
but a disintegration of countervailing forces in both South and North, what Professor Woodward calls "the relaxation of the opposition."328

The final hurdle which remained was the United States Supreme Court. The South went into that contest with an optimism born of unbroken victories in the federal courts on the issue of national power over privately imposed segregation. Now the issue would be the validity of state imposed segregation under the Fourteenth Amendment. Given the intensity of Southern feeling, the unconcerned if not sympathetic attitude of the North and the powerless economic and political position of Negroes in the North and the South, it would be a mistake to assume that the Court could have damned up the flood of Southern Jim Crow legislation of the 1890's and 1900's. But this does not mean that the Court could have done nothing. Within the area of the possible, an adoption of Harlan's views could have slowed down the march of Jim Crow legislation and strengthened the hands of white moderates, could possibly have preserved some specific areas (such as courtrooms, places of public political assembly and voluntary private desegregation) from enforced segregation, and could have placed the voice of the national constitutional conscience against a legally defined and law enforced stamp of inferiority on the Negro race. That these represented a minimal area of resistance and that the South would have found legal and extralegal ways to segregate the Negro seems clear; that the limited measure of resistance would have been morally important and practically significant, particularly as the extremist sentiments of the 1890's and early 1900's began to recede, would seem to be equally true.

The showdown in the Supreme Court came in the spring of 1896, with the Plessy case, an 1892 conviction of a Negro for violating an 1890 Louisiana railroad segregation law. As noted in the earlier discussion of this case, the point at issue between the Court and Harlan was the reasonableness of the Louisiana statute, measured in terms of whether it denied Negroes the equal protection of the laws required by the Fourteenth Amendment. Unlike the situation in the Civil Rights Cases, the language and intent of the framers was not a point of contention between the majority and Harlan. Both agreed that if the law operated to limit the legal or political rights of Negroes, it was unreasonable. Justice Brown's opinion met this issue by assuming that the state was imposing only social discrimination and that this could not be read as placing the onus of inferiority on the separated Negroes.

At this point, Harlan's Southern background becomes the most interesting feature of the case. With the exception of Justice Edward Douglas White, a former Louisiana Confederate and staunch Southern Democrat on the race issue, Harlan was the only member of the Court in 1896 who had lived in a former slave state through the days of the Black Codes and reconstruction, and who had observed Negroes barred from the state courts, terrorized at the polls and in their homes by bands of klansmen and agitated against by those who saw a chance for political success in an appeal to racial intolerance and

326. WoodWARn, op. cit. supra note 322 , at 51 . 
discrimination. From the start, therefore, Harlan's dissent breathed a spirit of presociological reality about the psychological and practical effects of segregation measures. First of all, Harlan pointed to the clear and open intent of the white supremacist leaders who had enacted these measures in order to force inferior positions upon the Negro; yet the Court treated this as irrelevant in its assessment of the normal implications drawn from state segregation. Second, Harlan warned that the surest way to maximize race difference and make accommodation between the races impossible would be to tolerate legal discrimination against the minority group, thereby giving the weapon of valid law to the most rabid irreconcilables and limiting the private liberty of civil rights moderates and liberals who might wish to continue peaceful contacts. Third, Harlan focused on the sense of inferiority which these laws would impose upon Negroes, analogizing the situation to a case he knew well from his reading and disliked intensely, the privilege-caste lines in Great Britain. To show the Court how unsound its reasoning was, Harlan enumerated a list of what he regarded as ridiculous and plainly unreasonable separate-but-equal measures: separation in streetcars and open vehicles; separation on the public streets; separation in jury-boxes, courtrooms, legislative galleries, and public debating places. Surely Harlan felt, these actions would have to be struck down by the Court, so it would be foolish for the Court to uphold this Louisiana law and give false hope to those "who affect to be disturbed at the possibility that the integrity of the white race may be corrupted. . ."327

How right Harlan was in his prediction as to the invitation to the white supremacists but how wrong he was in his conception of the Court drawing any lines against segregation was shown in the events of the next decade. Throughout the South Jim Crow laws were adopted for streetcars and steamboats, waiting rooms and waterfountains, theaters and public parks. Along with this wave of segregationist laws went legal disenfranchisement of the Negro by means of the poll tax, literacy clauses and the white primary, accompanied by violence and terrorist raids on Negro communities. ${ }^{328}$

The ultimate reach of the new segregation system came before the Court in . 1908, with Kentucky's law making it a crime for Negroes and whites to be educated together, willingly, in a private institution. The Berea College case must have been the ultimate indignity to Harlan. Berea promised another way in the South, the way of voluntary reconciliation through education and gradual understanding. Founded in the 1850's as an "anti-slavery, anti-caste, anti-sin" school to work among the non-slave-holding people of the hill country, Berea's student body in the 1880's, 1890's and 1900's was roughly half-white and half-Negro. The purpose of Berea was to let both the white and Negro students benefit by studying and living together and learning one another's human problems. No Booker T. Washington "humble work" center, Berea aimed at its Negro students becoming lawyers and legislators, professors and editors, architects and contractors, as well as farmers and mechanics with sound

327. 163 U.S. at 562 .

328. See works cited note 324 supra. 
judgment, cultural awareness and good character. All campus organizations were interracial, there were several Negro teachers and Negro board members, and the college flourished among its supporters, enjoying good relations with the nearby towns and a minimum of Klan attacks on its staff when they left the campus. 320

Such an island of amity standing to challenge the premises of the new segregationists could not be overlooked for long. In 1904 the Kentucky Legislature passed the law discussed earlier in the Berea College case.

To Harlan, the Kentucky law violated virtually every principle he had. It invaded personal liberty, infringed upon property rights in the tradition of the Dartmouth College case, and required a race bar in nonpublic activity. The Court's rationale, resting upon the sort of clever and devious ground which Harlan knew to deny substantive justice and demean the judicial process, was one of the worst he had ever seen. His dissent minced no words; with only Justice Day joining him, Harlan registered his protest against the total application of segregation and said his last about the enforced separation of the races. Forty-six years later, his Plessy and Berea College views on the meaning of enforced separation would be remembered and would become the law of the land. ${ }^{330}$

\section{John Marshall Harlan and the New Reconstruction}

Harlan's political career in Kentucky and his position as a steady dissenter from the Supreme Court of the Gilded Age stand by themselves as challenging illustrations of the American traditionalist in his finest role as defender of liberal values. There is an added meaning to Harlan's life which should be noted, though, a meaning derived from the civil rights conflict in which the nation now finds itself.

In 1864 John Harlan was a slave-holder, a defender of the constitutional rights of masters, and a firm opponent of abolition. Without the change in fundamental law by which the slaves were freed in 1865 , it is hard to conceive that Harlan could have leaped the hurdle of his beliefs and his environment to champion freedom for the Negro people of the South. In 1954 there were men like Harlan in the Southern and Border-South states who were committed to the defense of segregation because it was the legally-defined, unchallenged pattern of life in their communities. Without the Segregation Cases few of them would have been able to make the leap. Now, like Harlan, these men have been carried across the barrier by the change in fundamental law which the Segregation Cases decreed, and a new range of possibilities has opened to them.

329. Morgan, The Frutt of Thus Tree (1946); Peck, Berea's First Century, 1855-1955 (1955); Rogers, Birth of Berea College, A Story of Providence (1933).

330. The fact that Harlan, in writing the opinion of the Court in Cumming v. Board of Education, 175 U.S. 528 (1899), did not pass upon the validity of separate-but-equal schools has already been noted. See text at p. 689 supra. 
In 1870 , with the ratification of the Fifteenth Amendment, Negroes achieved the right to vote. Faced with the fact that these new voters would be exercising their ballots in sizeable numbers and would be like other Americans in having a weapon with which to demand their rights as citizens, Harlan, as a practical politician, added the interests of Negroes to those which he was prepared to consider in his platforms. Today, after an interim of forty years of grandfather clauses, poll taxes and white primaries, a series of Supreme Court opinions have restored the Negro's right to vote in the South. As the Negro vote mounts, latter-day Harlans, whether in two-party states or in one-party communities where Negro ballots are appreciable, will be adding up the eligible voters and some will be giving thought to serving the non-white as well as the white constituency.

Between 1868 and 1872, lawlessness swept Kentucky as it did many other parts of the South, as men committed to overthrowing the change in funda-. mental law sought to achieve their goals by violence and the disintegration of the community. Harlan, a man committed to order and law as his basic premise, braced up in anger against the radical irreconcilables and supported compliance. Between 1954 and the present, lawlessness has flared in Clinton, Tennessee, Montgomery, Alabama and other communities across the South. Though the record is still only partially written, it is clear that moderates have braced up in many of these areas-from their pulpits, their law offices, their stores and their farms- to stand firm for adherence to lawful procedures and perhaps for "deliberate speed."

This picture of the nation entering upon a second reconstruction era, one more sober and more hopeful than the first, would have been deeply pleasing to Mr. Justice Harlan. So would the realization that some Southern leaders were making the same "conversion" he had made in the 1860's and 1870's. Perhaps the most satisfying aspect to Harlan in the present situation would be the part played by the Supreme Court of the United States. For all his stinging rebukes to his colleagues, his distaste for judicial legislation and his occasional impatience with the judicial process, Harlan maintained an unswerving faith in the role of the Supreme Court as defender of the citizen's liberties and guardian of American constitutional ideals. That the Supreme Court of the 1950's has become the guiding force of the new reconstruction, in the spirit of his dissents on the segregation issue, may be seen as a particularly fitting vindication of John Marshall Harlan's faith. 


\section{THE YALE LAW JOURNAL}

Arthur L. Liman STEPHEN A. WEINER Comment Editors

Matthew T. Adars Malvin E. BanK JOHN W. BARNuM Thomas D. Barr WiLLIAM C. BASKIN, JR. Robert T. Basseches Frederick L. Bernstein Neil N. Bernstein David P. Bicks Judith Myra Bleich Newton D. BrenNer Guido Calabresi Laura M. Chaparan Paul H. DeCoster Robert J. Del Tufo Militon P. DeVane
ROBERT W. BLANCHETTE Editor-in-Chief

H. E. Dunkelberger, Jr. Rodney E. Eyster Article and Book Review ALvIN FriEDMAN Editor Note Editors

Axel H. Baum

Managing Editor

JoHN RICHARd DuFfield WILIIAMI L. F. FELSTINER Arthur Fleischer, JR. Gerald T. Floms Seth E. Frank VICTOR S. FRIEDMAN Morton I. Greenberg Milton S. Gwirtzman Alan M. Hofmanan ALAN J. Hruska WuLLIAM E. Huth Lloyd J. Keno David Klingsberg HAROLD S. LEVY IRWIN A. LEVY

Marie MCMaHon Business Secretary
JULIUS LEWIS RICHARD MaRLIN RICHARD M. MEYER Jerrold L. Morgulas Hugh G. MoultoN WALTER W. OBerRetT Richard W. Pendeleton, JR. Burton RafFer JEROME HowARD REICHMAN RICHARD J. SEXTON StEphen N. SHularan LEWIS A. Stern Charles W. Thomasson Stanley E. Tobin Frank E. G. Went ROBERT L. WEINBERG

\section{CONTRIBUTOR TO THIS ISSUE}

Alan F. Westin. A.B. 1948, University of Florida; LL.B. 1951, Harvard University. Senior Fellow, Yale Law School, 1956-57; Assistant Professor of Government, Cornell University. Member of the District of Columbia Bar. 